University of Rhode Island

DigitalCommons@URI

Open Access Master's Theses

1980

\title{
The Evolution of Regional Cooperation: The Case of the Martha's Vineyard Commission
}

\author{
William S. Voelker \\ University of Rhode Island
}

Follow this and additional works at: https://digitalcommons.uri.edu/theses

\section{Recommended Citation}

Voelker, William S., "The Evolution of Regional Cooperation: The Case of the Martha's Vineyard Commission" (1980). Open Access Master's Theses. Paper 724.

https://digitalcommons.uri.edu/theses/724

This Thesis is brought to you for free and open access by DigitalCommons@URI. It has been accepted for inclusion in Open Access Master's Theses by an authorized administrator of DigitalCommons@URI. For more information, please contact digitalcommons-group@uri.edu. 
THE EVOLUTION OF REGIONAL COOPERATION: THE CASE OF THE MARTHA'S VINEYARD COMMISSION

A RESEARCH PROJECT SUBMITTED IN PARTIAL FULFILLMENT OF THE REQUIREMENTS FOR THE DEGREE OF MASTER OF COMMUNITY PLANNING

UNIVERSITY OF RHODE ISLAND 1981 


\section{MASTER OF COMMUNITY PLANNING}

RESEARCH PROJECT

OF

WILLIAM S. VOELKER

Approved:

Major Professor

Director

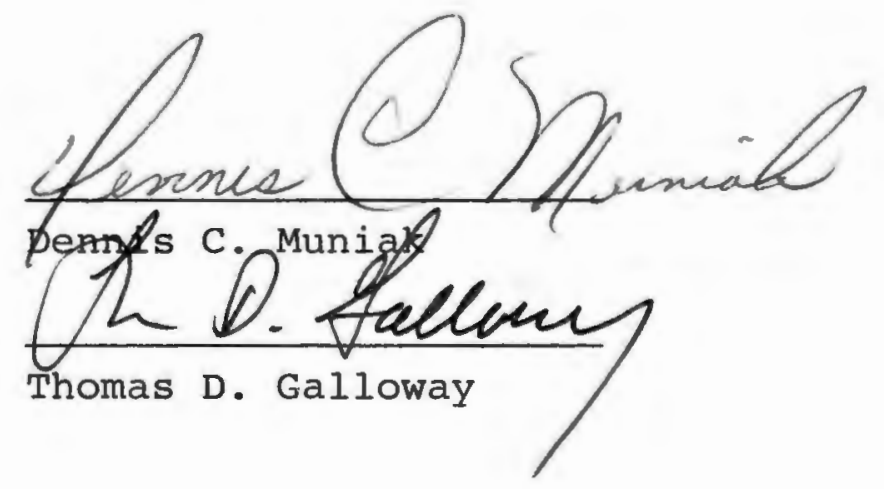


INTRODUCTION . . . . . . . . . . . . . 1

I. BACKGROUND ................. 3

II. THE CREATION OF THE MARTHA'S VINEYARD COMMISSION. .10

III. THE REGULATORY POWERS . . . . . . . . . . . . 18

IV. THE WITHDRAWAL OF EDGARTOWN . . . . . . . . 24

V. TISBURY AND THE STEAMSHIP AUTHORITY OUESTION . . 33

VI. THE EVOLVING LEGISLATION . . . . . . . . . 56

VII. ON REFLECTION . . . . . . . . . . . . . . . . . .

APPENDIX:

CHAPTER 637 . . . . . . . . . . . . . . .

CHAPTER 831 ............... . . . . . .

DCPC REGULATIONS FOR EDGARTOWN . . . . . . .114

DRI DECISION FOR SECOND SLIP . . . . . . . 120

SSA PROPOSED COMPROMISE CONDITIONS . . . . . . 129

HISTORY OF ANNUAL BALLOT QUESTIONS . . . . . . .132 


\section{INTRODUCTION}

During the late $1960^{\prime}$ 's and early 19.70's, it was recognized by both Federal and Massachusetts authorities that the six towns of the Island of Martha's Vineyard could not manage the tremendous growth pressures they were experiencing. Various pieces of legislation, designed in part to create a regional regulatory body, were introduced at both levels of government to accomplish what the six towns could not do acting independently. Federal legislation was not well received by the residents of Martha's Vineyard, as it was perceived as intervention into locally cherished home rule perogatives.

In 1974, state efforts resulted in the creation of the Martha's Vineyard Land and Water Commission. The Commission is a regional agency uniquely empowered to regulate critical districts and certain types of development. The commission is able to regulate sensitive areas and developments which are determined to be of regional importance. Hence, the Commission's powers are far broader than any local zoning ordinances and by-laws.

This regional approach to managing growth on Martha's Vineyard was designed to be a pilot project for possible application elsewhere in the state. The commission has been perceived in contrasting ways by vineyard residents. It has been welcomed as a necessary approach to mitigating growth pressures, and abhorred as an unwelcome pariah seeking to supercede home rule. 
When carrying out it's legislative mandate, the Commission has often encountered resistance from local authorities and interest groups. Two of the original six member towns have withdrawn from the Commission in an atmosphere of crisis resulting from the regional body's exercise of their regulatory authority. "Regional purpose" is something new to the residents of Martha's Vineyard and this has contributed to many of the problems encountered by this unique regional agency.

Withdrawal has precipitated changes in the Commission's enabling legislation. An evolution is taking place where the Commission is being molded by the people of Martha's Vineyard to become a more acceptable regulatory agency. The Commission will perhaps become a regional instrument of home rule.

Presented here is a review of significant events in the history of the Martha's Vineyard Commission. Events leading to it's creation and those contributing to the withdrawal of the towns will be examined with the intent of gleaning as much insight as is possible from these events. The evolving legislation will also be examined in light of the withdrawal of the two municipalities. To conclude, some general insights and observations concerning the Commission's future will be presented. 


\section{BACKGROUND}

The Island of Martha's Vineyard lies fives miles off the Cape cod coastline. It is considered by its residents and others throughout Massachusetts to be the "jewel of the Commonwealth" due to its unspoiled and unique beauty. The Vineyard is the largest of the islands in Nantucket Sound, 1 where, for many years, people have travelled to avail themselves of the island's diverse attractions. Aside from the miles of unspoiled beaches, the vineyard offers the visitor a laboratory for scientific and historical study.

Evidence of the whaling industry, which once dominated the local economy, can be seen as one walks the streets of Edgartown, where many of the whaling captains made their home in the sturdy, white houses which still stand. Archeological remnants of the Native American population give further historical significance. The geologist is presented with a study of glacial recession as the island is formed by glacial moraine and terminal outwash. The unique and splendid clay cliffs at Gay Head offer further study of glacial recession. The Vineyard is also the home of a state lobster hatchery, a solar shellfish hatchery, and possesses unique wildlife, vegetation, and ecosystems.

Six strongly independent towns make up the 98 square miles of the Vineyard: Gay Head, Chilmark, West Tisbury, Tisbury, Oak Bluffs, and Edgartown. In recent years, these towns have become second-home locations for many of the world's celebrities and wealthy individuals. The second-home industry has been growing consistently over the last two 
decades, and this has been an issue of concern in vineyard affairs. ${ }^{2}$ (Table I indicates trends in the single family sector of the local housing market.)

The permanent year-round population in 1980 was 8942 , an increase of 46 percent since $1970 .^{3}$ The seasonal summer population swelled to 53,000 , occasionally peaking to 90,000 on selected holidays. ${ }^{4}$ Reports from Vineyard residents indicate that this was the biggest year for tourism ever recorded. The $\$ 14,200$ median income for the Vineyard (Dukes County) is well below the state average of $\$ 17,900 .^{5}$ Major industries, according to number of firms are: hotels and rooming houses, eating and drinking places, building and construction firms, miscellaneous retail, and fishing. The towns of Oak Bluffs, Tisbury, and Edgartown hold almost three-quarters of the total year-round population. (Table II indicates changes in the Vineyard's population and housing units ince 1970.)

A 1970 land use inventory shows that the island was 9 percent developed, with 11 percent dedicated as public open space, and the remainder considered vacant. ${ }^{6}$ (Table III shows some of the changes in land use patterns over a 20 year period beginning in 1951.) A critical issue on the island is it's limited supplies of fresh water. Certain sources indicate that the value for undeveloped land has risen from an estimated $\$ 7,500$ per acre in 1973 , to $\$ 20,000$ per acre (for inland property) in 1980.7 Ocean front property and land near tidal ponds is far more expensive. 
TABLE I

BUILDING PERMITS FOR SINGLE UNIT, DETATCHED DWELLINGS

\begin{tabular}{|c|c|c|c|c|c|c|c|c|}
\hline TOWNS/YEAR & 1972 & 1973 & 1974 & 1975 & 1976 & 1977 & 1978 & 1979 \\
\hline EDGARTOWN & 75 & 112 & 92 & 37 & 32 & 60 & 121 & 83 \\
\hline OAK BLUFFS & 71 & 55 & 23 & 15 & 37 & 43 & 49 & 39 \\
\hline CHIIMARK & $\mathrm{NR}^{*}$ & $\mathrm{NR}$ & NR & $\mathrm{NR}$ & NR & 19 & 5 & 20 \\
\hline TISBURY & NR & $\mathrm{NR}$ & $\mathrm{NR}$ & $\mathrm{NR}$ & 21 & 46 & 35 & 54 \\
\hline WEST TISBURY & $\mathrm{NR}$ & $\mathrm{NR}$ & NR & NR & 19 & 23 & 17 & 27 \\
\hline GAY HEAD & NR & NR & NR & NR & $\mathrm{NR}$ & NR & NR & 1 \\
\hline
\end{tabular}

*Not reporting

SOURCE: U.S. CENSUS OF POPULATION AND HOUSING 
TABLE II

POPULATION AND HOUSING UNIT CHANGES 1970 - 1980

\begin{tabular}{lrrrrrl} 
& \multicolumn{2}{c}{ PERSONS } & \multicolumn{3}{c}{ HOUSING UNITS } \\
& 1970 & 1980 & \multicolumn{1}{c}{$\%$} & 1970 & 1980 & \multicolumn{1}{c}{$\%$} \\
CHILMARK & 340 & 489 & 43.8 & 631 & 831 & 31.7 \\
EDGARTOWN & 1481 & 2204 & 48.8 & 1254 & 2255 & 79.8 \\
GAY HEAD & 118 & 220 & 86.4 & 183 & 306 & 67.2 \\
OAK BLUFFS & 1385 & 1984 & 43.2 & 1535 & 2306 & 50.2 \\
TISBURY & 2757 & 2972 & 31.7 & 1330 & 2089 & 57.1 \\
WEST TISBURY & 453 & 1010 & 123.0 & 461 & 913 & 98.0 \\
& & & & & & \\
\hline
\end{tabular}

SOURCE: 1980 U.S. CENSUS OF POPULATION AND HOUSING 
TABLE III

TWENTY YEARS OF CHANGE IN LAND USE ON MARTHA'S VINEYARD

CHILMARK

1951 TOTALS

\begin{tabular}{lc}
\hline Land Uses & Acres \\
\hline Forest Land & 8816 \\
\hline $\begin{array}{l}\text { Agriculture or } \\
\text { Open Iand }\end{array}$ & 2672 \\
\hline $\begin{array}{l}\text { het Land } \\
\text { Mining, Waste } \\
\text { Disposal }\end{array}$ & 780 \\
\hline $\begin{array}{l}\text { Urban Iand } \\
\text { Outdoor Recrea- } \\
\text { tion }\end{array}$ & $\mathrm{NR}$ \\
\hline \\
GRAND TOTAL
\end{tabular}

1971 TOTALS

\begin{tabular}{lc}
\hline Land Uses & Acres \\
\hline $\begin{array}{l}\text { Forest Land } \\
\text { Agriculture or }\end{array}$ & 8635 \\
\hline Open Land & 1574 \\
\hline $\begin{array}{l}\text { Wet Land } \\
\text { Mining, Waste } \\
\text { Disposal }\end{array}$ & 1435 \\
\hline $\begin{array}{l}\text { Urban Land } \\
\text { Outdoor Recrea- } \\
\text { tion }\end{array}$ & 10 \\
\hline & 486 \\
\hline GRAND TOTAL & 12,304 \\
\hline
\end{tabular}

\section{EDGARTOWN}

1951 TOTALS

\begin{tabular}{lc}
\hline Land Uses & Acres \\
\hline Forest Land & 11896 \\
\hline $\begin{array}{l}\text { Agriculture or } \\
\text { Open Land }\end{array}$ & 4484 \\
\hline $\begin{array}{l}\text { Wet Land } \\
\text { Mining, Waste } \\
\text { Disposal }\end{array}$ & 2204 \\
\hline $\begin{array}{l}\text { Urban Land } \\
\text { Outdoor Recrea- } \\
\text { tion }\end{array}$ \\
\hline \\
GRAND TOTAL & NR \\
\hline
\end{tabular}

GAY HEAD

1951 TOTALS

\begin{tabular}{lc}
\hline Land Uses & Acres \\
\hline Forest Land & 2528 \\
\hline $\begin{array}{l}\text { Agriculture or } \\
\text { Open Land }\end{array}$ & 888 \\
\hline $\begin{array}{l}\text { Wet Land } \\
\text { Mining, Waste } \\
\text { Disposal }\end{array}$ & 640 \\
\hline $\begin{array}{l}\text { Urban Land } \\
\text { Outdoor Recrea- } \\
\text { tion }\end{array}$ & 0 \\
\hline & NR \\
\hline
\end{tabular}

1971 TOTALS

\begin{tabular}{lc}
\hline Land Uses & Acres \\
\hline Forest Land & 11871 \\
\hline $\begin{array}{l}\text { Agriculture or } \\
\text { Open Land }\end{array}$ & 2901 \\
\hline $\begin{array}{l}\text { Wet Land } \\
\text { Mining, Waste } \\
\text { Disposal }\end{array}$ & 2730 \\
\hline $\begin{array}{l}\text { Urban Land } \\
\text { Outdoor Recrea- } \\
\text { tion }\end{array}$ & 952 \\
\hline & 566 \\
\hline
\end{tabular}

1971 TOTALS

\begin{tabular}{lc}
\hline Land Uses & Acres \\
\hline $\begin{array}{l}\text { Forest Land } \\
\text { Agriculture or } \\
\text { Open Land }\end{array}$ & 3051 \\
\hline $\begin{array}{l}\text { Wet Land } \\
\text { Mining, Waste } \\
\text { Disposal }\end{array}$ & 641 \\
\hline $\begin{array}{l}\text { Urban Land } \\
\text { Outdoor Recrea- } \\
\text { tion }\end{array}$ & \multicolumn{1}{c}{403} \\
\hline & 77 \\
\hline
\end{tabular}


OAK BLUFFS

1951 TOTALS

\begin{tabular}{lc}
\hline Land Uses & Acres \\
\hline $\begin{array}{l}\text { Forest Land } \\
\text { Agriculture or }\end{array}$ & 3052 \\
Open Land & 992 \\
\hline $\begin{array}{l}\text { Wet Land } \\
\text { Mining, Waste } \\
\text { Disposal }\end{array}$ & 750 \\
\hline $\begin{array}{l}\text { Urban Land } \\
\text { Outdoor Recrea- } \\
\text { tion }\end{array}$ & 550 \\
\hline & NR \\
\hline
\end{tabular}

1971 TOTALS

\begin{tabular}{lc}
\hline Land Uses & Acres \\
\hline $\begin{array}{l}\text { Forest Land } \\
\text { Agriculture or }\end{array}$ & 3046 \\
Open Land & 463 \\
\hline $\begin{array}{l}\text { Wet Land } \\
\text { Mining, Waste } \\
\text { Disposal }\end{array}$ & 805 \\
\hline $\begin{array}{l}\text { Urban Land } \\
\text { Outdoor Recrea- } \\
\text { tion }\end{array}$ & $\mathbf{7 7 8}$ \\
\hline & 196 \\
\hline
\end{tabular}

TISBURY

1951 TOTALS

\begin{tabular}{lc}
\hline Land Uses & Acres \\
\hline Forest Land & 3264 \\
\hline $\begin{array}{l}\text { Agriculture or } \\
\text { Open Land }\end{array}$ & 488 \\
\hline $\begin{array}{l}\text { Wet Land } \\
\text { Mining, Waste } \\
\text { Disposal }\end{array}$ & 580 \\
\hline $\begin{array}{l}\text { Urban Land } \\
\text { Outdoor Recrea- } \\
\text { tion }\end{array}$ & 527 \\
\hline & NR \\
\hline
\end{tabular}

WEST TISBURY

1951 TOTALS

\begin{tabular}{lc}
\hline Land Uses & Acres \\
\hline Forest Land & 13584 \\
\hline $\begin{array}{l}\text { Agriculture or } \\
\text { Open Land }\end{array}$ & 2272 \\
\hline $\begin{array}{l}\text { Wet Land } \\
\text { Mining, Waste } \\
\text { Disposal }\end{array}$ & 854 \\
\hline $\begin{array}{l}\text { Urban Land } \\
\text { Outdoor Recrea- } \\
\text { tion }\end{array}$ & 180 \\
\hline & $\mathrm{NR}$ \\
\hline
\end{tabular}

1971 TOTALS

\begin{tabular}{lc}
\hline Land Uses & Acres \\
\hline Forest Land & 3188 \\
\hline $\begin{array}{l}\text { Agriculture or } \\
\text { Open Land }\end{array}$ & 288 \\
\hline $\begin{array}{l}\text { Wet Land } \\
\text { Mining, Waste } \\
\text { Disposal }\end{array}$ & 622 \\
\hline $\begin{array}{l}\text { Urban Land } \\
\text { Outdoor Recrea- } \\
\text { tion }\end{array}$ & 622 \\
\hline & 128 \\
\hline
\end{tabular}

*Not recorded as such in 1951 .

Source: Remote Sensing 20 years of change in Barnstable, Dukes, and Nantucket Counties, Massachusetts, 1951-1971, William P. MacConnell, et.al., Massachusetts Agricultural Experiment Station, Research Bulletin 623, November, 1974 . 


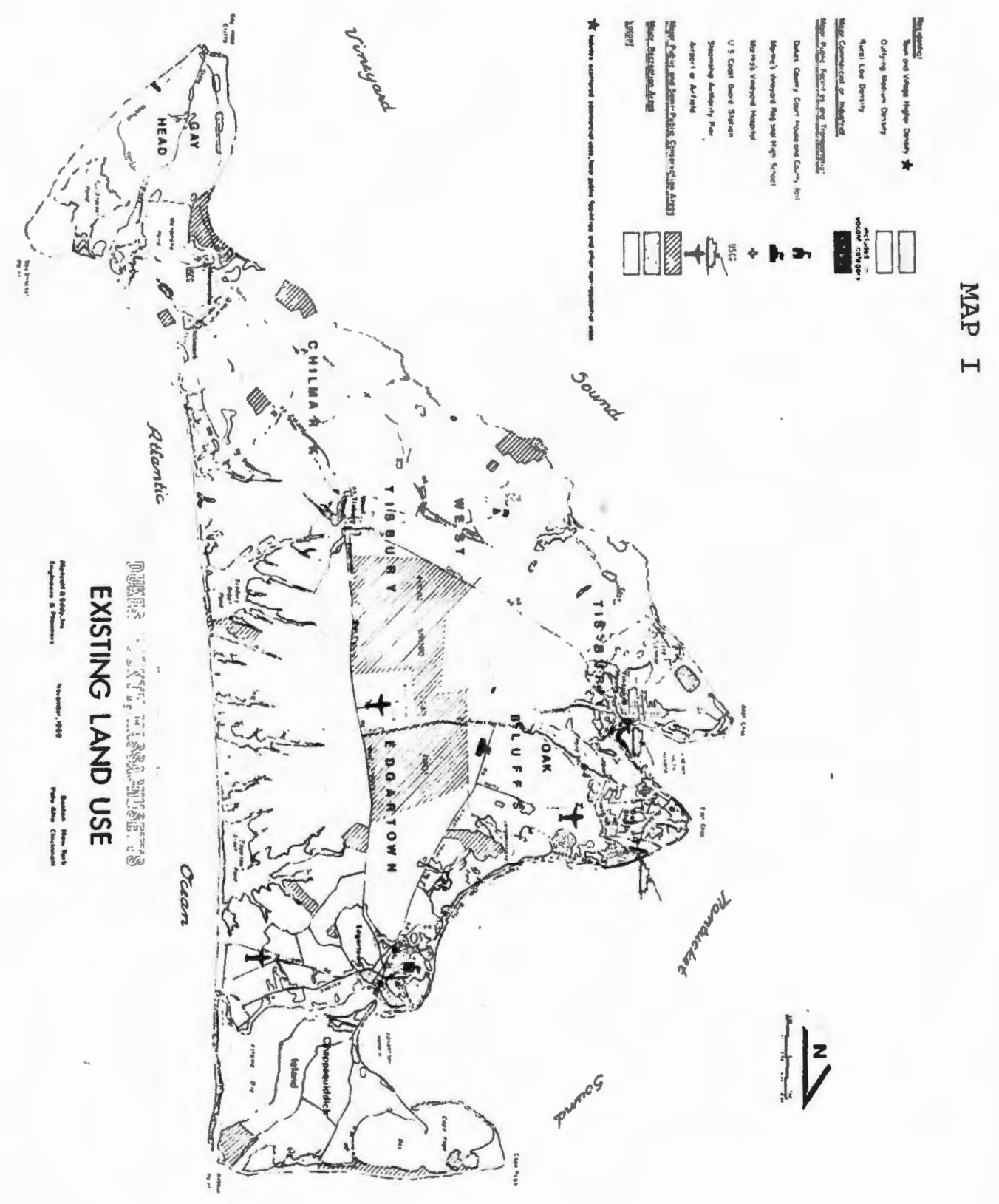


The six towns on the Vineyard are faced with the challenge of protecting the island's character, and it's scarce inventory of fresh water which limits the supply of developable land. Martha's Vineyard's economy is primarily tourist based. 8 It has grown in keeping up with the increasing numbers of visitors over the last two decades. Any substantial negative alterations in the island's quality could have devastating impacts on the local economy. While this is a primary concern, there is also some interest for broad based economic development which will decrease the effects of the cyclical nature of business and reduce islanders dependency on tourism.

Many islanders are informed and concerned with the issues they must face, and are seeking ways to solve the problems encroaching upon island life. These people are divided as to the solution: some see that their affairs are best managed by the towns through home rule; others feel that the powers of a regional agency, created by either state or federal legislation is the best solution; still others are indifferent and often unaware of the nature and magnitude of the potential problems facing the Vineyard. All of these factors are important to the discussion which follows; the feelings of the people involved is essential to understanding the issues here presented.

II. THE CREATION OF THE MARTHA'S VINEYARD COMMISSION One might be inclined to think of an island as a closed system whose insularity would facilitate planning at a regional level without the spillover effects which would occur on the mainland. Martha's Vineyard is very much an open 
system and is by no means insular as the growing numbers of visitors from the mainland indicate. The development of second-homes is a year round industry on the island, and efforts are underway to attract "clean type" industries to bolster the primarily tourist based economy.

Much attention was given to this beautiful, diverse island as the Commonwealth of Massachusetts began to recognize the importance of using policy power regulations to promote good planning and avoid the consequences of poorly planned development. Martha's Vineyard was widely recognized as a valuable, unspoiled resource of statewide significance. The general feeling was that some efforts should be made to better coordinate growth and use of island resources. 9

The earliest efforts were initiated in 1962 by Dean Swift, who, as a newly elected county Commissioner, sought to strengthen the role of the county in island affairs. Federal funds were sought and received and, by 1966, the Dukes County Planning and Economic Development Commission was operating as an advisory and coordinating body for the island towns. 10 Shortly after it's creation, the Commission hired Metcalf and Eddy, a Boston consulting firm, to prepare a comprehensive plan for the county. By April of 1971, the Comprehensive and Summary Reports were ready for publication. The Summary Report contained a stern warning which predicted that the Vineyard was in danger of being "raped" by developers, and would contract "terminal environmental cancer" by 1975 unless appropriate action was taken. This terminology indicated that uncontrolled, intensive development would ruin the 
Vineyard's character and adversely impact the limited fresh water supplies. It also recommended that the State create and fund an agency (in replacement of DCPEDC) which would have overriding authority in land use matters as well as the power of eminent domain. The report further recommended a federally sponsored "island trust" if the state failed to take action in two years. ${ }^{11}$

This report was shelved by the Commission who refused to release it to the general public. Instead, a watered down, cleaned-up version omitting the stern warning was released. However, there is sufficient itimacy on the Vineyard not to allow secrets such as this to be very well kept. Eventually, The Vineyard Grapevine, one of only two local papers, revealed the contents of the original summary Report to the alarm of many residents.

Federal legislators were made aware of the Report in a letter sent to U.S. Senators Kennedy, Brooke, and Representative Hastings Keith. It called for them to sponsor appropriate legislation to protect the Island. This same letter was also published in The New York Times. ${ }^{12}$

While the general local reactions to a "cover-up" of the original Summary Report and the possibility of federal intervention in local affairs were hostile, public awareness and concern for the Vineyard's future were also generated. This sequence of events, beginning in 1971, was something of a watershed mark in vineyard history. One obvious outcome was that the towns began to develop their own zoning ordinances and master plans. Most of these were 
being enforced by 1974. The towns also moved to create planning boards furhter attesting to an awakening of their consciousness.

Since 1967, Senator Edward Kennedy had explored alternatives for protecting the Nantucket Sound Islands. His fear was that the uniqueness and character of these islands would soon be lost and he felt that there was a compelling national interest in protecting them.

On September 29, 1971, Kennedy introduced a bill into the Congress which would authorize the secretary of the Interior to conduct a study of the islands to determine whether they should be made part of the Cape Cod National Seashore. 13 During the Congressional debates which followed, it became apparent that this proposal was not appropriate. Public meetings on the Vineyard made it abundantly clear that federal intervention in island affairs would be met with strong resistance.

Kennedy ignored the reactions from island residents and worked on a new approach to preservation and conservation. After secret meetings with selected islanders, Senator Kennedy introduced the Nantucket Sound Islands Trust Bill in April of 1972.14

The stated purpose of this bill was to preserve and conserve the unique values of the Nantucket Sound Islands for the enjoyment of future generations. If enacted, it would have established a trust commission with 21 members, all but three of whom were to be islanders. The bill divided the land into four categories designated by a predrawn map. In the "forever wild" category, there was to be 
no further development; the "scenic preservation" lands were not to be developed beyond the existing intensity of use; "county planned" and "town planned" categories provided that land use controls would remain the province of these bodies so long as the ordinances controlling the uses were approved by the trust commission and the secretary of Interior as was consistent with the purposes of the bill. There was also a provision for land acquisition with fully 80 percent of the proposed funding set aside for this purpose. This legislation placed Dukes and Nantucket Counties into an all encompassing land use and conservation trust. It carried a suggested appropriation of $\$ 25,000,000$, $80 \%$ of this for land acquisition, the remaining $20 \%$ for assorted development purposes.

Island residents were generally stunned by this bill. In particular, real estate interests and island selectman reacted the most bitterly. Reactions included calling Kennedy "inhumane, arrogant, and high handed" to "turning the Vineyard into an Indian reservation."

The Senator persisted, however, and prepared various amendments to the bill based on the suggestions of concerned islanders.

Most of the negative reactions to the bill centered around the issues of: home rule; the secrecy surrounding the introduction of the bill; the lack of prior consultation with island officials; a proposed moratorium on development which could threaten the livelihood of islanders in the building trades; the fear that all beaches would be open to the public; the potential encroachment on private property 
rights; and the fact that the bill seemed to be the handiwork of "rich" summer residents.

Some islanders were determined to get involved and make their voice heard. Various groups and organizations met with members of the Senator's staff and suggested changes to the bill to clarify it and to increase the measures of local control. However, according to an informal poll taken by the Dukes County Commission, most islanders were opposed to the federal legislation.

Based on the suggestions from the interested groups, Kennedy introduced an amendment to the original bill in July 1972. ${ }^{15}$ This amendment included provisions for more local control, a separate trust commission for Martha's Vineyard, the reduction of the secretary of the Interior's powers to act independently, and an easing of land restrictions.

During this same period, a number of island officials, most in opposition to the Kennedy bill, invited Massachusetts Governor Sargent to discuss the problems of the vineyard. Governor sargent did not take a definitive stand, either pro or con, on the proposed legislation. Rather, he indicated his awareness of the island's problems and promised to work with local officials to press for new state legislation that would help to enchance local planning and growth control capabilities.

The neutral stand taken by Governor Sargent is seen as a way to alleviate a potentially volatile political dilemna. He did not want to appear to be offering a land use proposal 
to counter the Kennedy bill and members of his staff were careful to point this out.

Lewis Crampton, the Commissioner of the Department of Community Affairs, met with island selectmen and asked if they would support the designation of the Vineyard as a demonstration site for formulating and testing possible future land use legislation which could be used statewide. Meanwhile, Crampton was working with local officials, organizations, and private citizens and other groups to develop a grass roots regional control agency sponsored by state legislation. These efforts were productive, and, on March 21, 1973, a draft bill was presented to the All Island Selectmen's Association.

This draft bill called for the creation of a Regional Resource Agency consisting of twelve members: one selectmen from each town, three county Commissioners, the secretary of Communities and Development, and one representative from each local conservation commission and the Martha's Vineyard Chamber of Commerce. The expenses would be paid by per capita assessments against the towns. The agency would be able to designate Districts of Critical Planning Concern and adopt regulations governing Developments of Regional Impact. The bill gave the Agency the power to adopt an official map reserving land for government purposes.

Crampton seems to have realized much earlier that Mr Kennedy the importance of gaining the cooperation of island residents. Frequent meetings with the aforementioned parties resulted in a measure of confidence for these efforts, 
something which appears to have been lacking in the Kennedy proposal.

Work was continuing on both the state and federal bills simultaneously. By May of '73, the Senator had introduced a fourth version of his bill. ${ }^{16}$ In contrast to this preservation bill, the state bill was essentially a planning bill with regulation rather than acquisition as the major device for controlling development.

The state bill was reworked with extensive input from local officials and residents. During August of 1973, the State Joint Committee on Natural Resource and Agriculture held public hearings on the bill and proposed further changes. While the legislative committee worked on it's version, sponsors and proponents of the federal bill were seeking further compromise and looked for areas of agreement between the two bills. Efforts were being directed at developing a combined federal/state legislative program. Essentially, the federal bill would be a companion piece to the state bill which had received overwhelming support in an island wide, nonbinding referendum in March of 1974: 1,305 in favor to 64 against. Again, the legislative committee revised the bill; this time into it's final version. On July 27, 1974 the Martha's Vineyard Land and Water Commission was created by the state through Chapter 637 of the Acts of 1974 (see Appendix). Towns were automatically members of the Commission and this membership was considered permanent. Funding for the agency was to come from federal and state agency grant money, plus an 
annual assessment from each of the six towns.

The passage of this bill was expected to boost the chances of the federal bill, but, as of this writing, the bill remains in committee limbo. While there is considerable doubt that the bill will ever be revived, it does offer some attractiveness as a complement to the state act; particularly with regard to the availabilities of funds for land acquisition. However, the fear of federal intervention and the distrust of the sponsors of the bill remain as obstacles to it's acceptance by the "Yankee" independent residents of Martha's Vineyard. There does remain a provision in the state act for the inclusion of a member of the President's cabinet (presumably the secretary of the Interior) to be disignated as a member of the Commission.

III. THE REGULATORY POWERS

The Martha's Vineyard Land and Water Commission met for the first time on November 21,1974 and assumed all powers, duties, staff, monies, and contracts of the Dukes county Planning and Economice Development Commission. The act creating this agency sets up the Commission as a public corporate body with jurisdiction over the island except for lands owned by the state and Indian Common Lands which comprise less than 1 percent of the total land area. 17

In it's original form, the Commission consisted of 21 members, one member from each town, appointed by or a member of the board of selectmen, nine persons elected at-large (at least one from each town, but not more than two), one County Commissioner appointed by the County Commissioners, 
one cabinet member appointed by the Governor, and four persons appointed by the Governor whose principle residence is not on Martha's Vineyard.

Aside from the duties assumed from the DCPEDC, the Commission is empowered to adopt regulations for and designate Districts of Critical Planning Concern (DCPC) and to approve, disapprove, or approve with conditions Developments of Regional Impact. These techniques are adapted from the American Law Institute's Nodel Land Development Code. 18

A District of Critical Planning Concern could be nominated for consideration by the Commission, selectmen, local planning boards, local boards of health, conservation commissions, or by a petition by twenty-five taxpayers of any island town. A DCPC is a geographic area which is of regional importance and in need of special protection and qualifies as an economic, cultural, or natural resource (see Appendix, Chapter 637, Section 9, or Chapter 831, Section 8 for specific qualifications).

Districts of Critical Planning Concern serve to protect areas possessing unique, natural, historical, scientific features, or cultural resources of regional or statewide significance. Under Chapter 637, the steps for an area to be nominated and regulated are here included (using hypothetical dates (See Figure I). These steps are the original process, not as it takes place today. These changes and their causes will be dealt with later.

FIGURE I CHAPTER 637 DCPC REVIEW PROCESS

1. MVC receives nomination for DCPC April 1, 1975. 
A. MVC must accept or reject proposed DCPC by May 15, 1975 (45 days).

2. If accepted for consideration, MVC has 60 days to designate or not designate a DCPC.

A. With acceptance for consideration, a moratorium on construction begins.

3. With designation of DCPC, MVC prepares guidelines for district regulations.

A. Town boards have 3 months to draft regulations.

4. Moratorium terminates when final regulations are in place.

A. Towns have one year to finalize requlations.

In most cases, DCPC's are overlay districts which are superimposed over existing zoning districts, zoning regulations, health regulations, conservation regulations, and other land use regulations affecting the town. These overlay regulations are supplementary to such existing regulations, and, should there be a conflict, the more limiting regulations would prevail. In towns which had no zoning regulations of any kind, DCPC's have been developed to serve as the primary regulations for that town. At this time, the Commission has designated eight DCPC's. (Map II shows five of these districts).

DCPC regulations must be adopted and administered by the towns as if they were part of their development ordinacnes and by-laws, even if the town should withdraw from the regional agency. Municipalities are prohibited from granting a development permit within a DCPC except in accordance with the regulations. They may, however, rescind or amend these regulations, but only in the manner provided for adoption and approval as is stated in the legislation. (See Appendix Chapter 637, Section 11, or Chapter 831, Section 10). 
MAP II

DESIGNATED DISTRICTS OF CRITICAL PLANNING

CONCERN

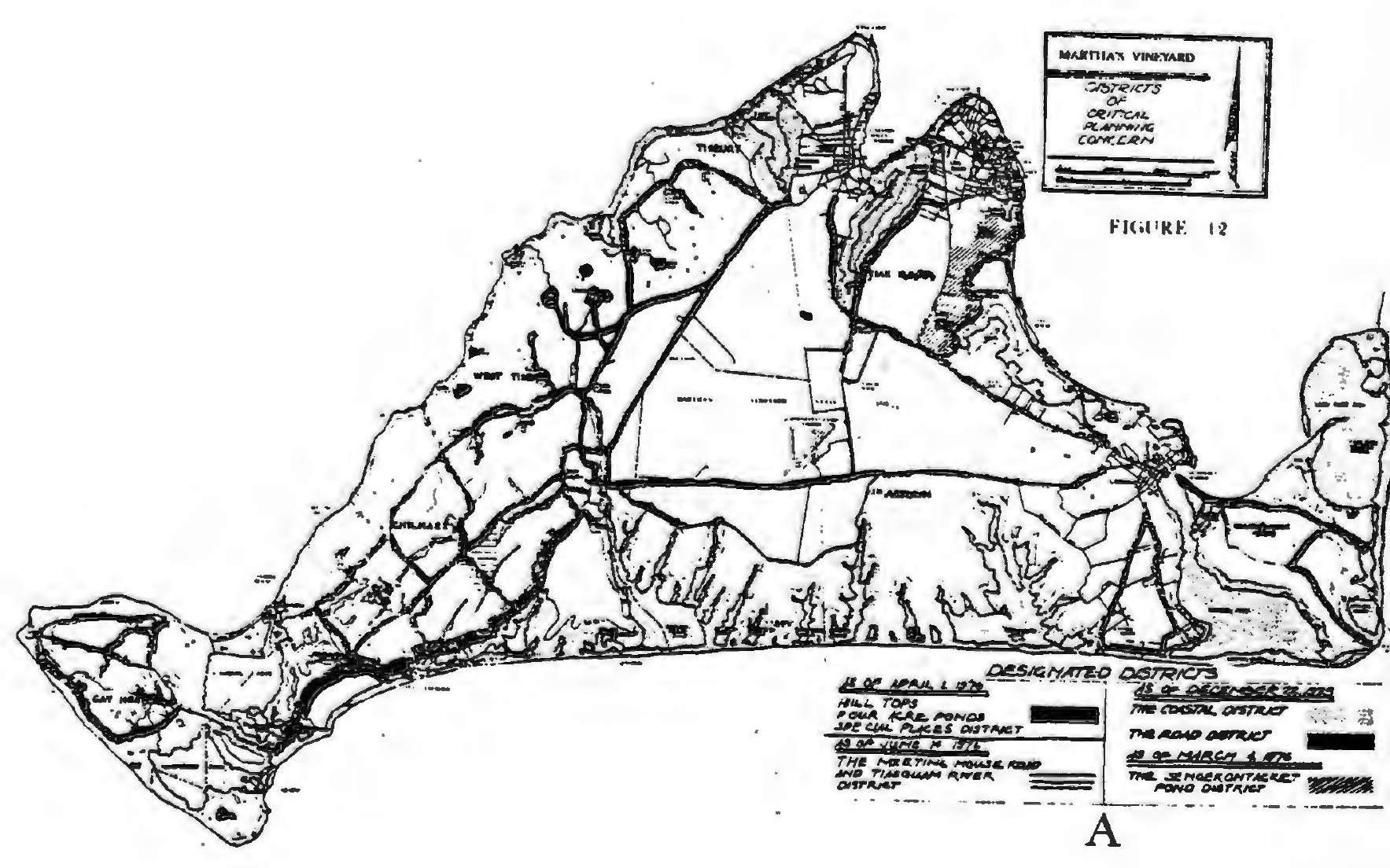

SOURCE: Martha's Vineyard Commission 
The second type of regulatory power lies in the Commission's ability to regulate Developments of Regional Impact (DRI). A DRI occurs with any change in structures, land, or use as defined by location, size, or type. Developments of Regional Impqct differ from Districts of Critical Planning Concern in that DCPC's focus on the characteristics of the land, whereas DRI's focus primarily on the kind of development being proposed. The act specifies seven considerations which the Commission must consider in adopting standards and criteria to determine whether or not a development is one of regional impact. These are: 1) environmental problems, 2) size, 3) traffic, 4) number of persons involved, 5) extent to which a regional market is being served, 6) proximity to waterways or public lands and municipal boundaries, 7) the need for regional services.

The Commission has the responsibility to approve, disapprove, or approve with conditions any Development of Regional Impact. These developments are weighed according to their benefits and detriments, their consistency with local plans, regulations, and by-laws, and any conflicts with DCPC regulations. The legislation lists specific criteria to be used in weighing benefits against detriments (see Appendix, Chapter 637, Section 16, and Chapter 831, Section 15 for specific criteria).

The Commission is permitted to receive funds from any state or federal agency. In addition to this funding, the Commission receives an annual assessment from each member town. In January of each year, the agency calculates it's 
total expenses for the following fiscal year, deducts estimated grants and contributions, and pro-rates the net expenses to each town based on it's latest equalized valuation for property tax purposes. This is not to exceed .036 percent of this valuation. 19

A main strength of this set of land use controls is that decision-making is still locally based. The decisions to be made at the regional level are clearly defined by the legislation. The DCPC and DRI processes give the agency the ability to strike a balance among conflicting interests and island needs. The MVC gives the six towns a forum in which to work together to protect their common interests. However, this system will only work if the towns take some measure of responsibility and make an effort to solve their common problems.

As was noted earlier, the six towns of Martha's Vineyard are very independent and believe firmly in their right to govern their own affaris. This was reflected in their inputs into Senator Kennedy's efforts and the Crampton Bill. Aside from the negative reactions, the primary concern was that the towns retain a definite voice and discretionary powers in the regulatory process. As will be seen in the following accounts, these issues would resurface numerous times after the passage of the Crampton legislation. The regulatory powers continue to evolve as do the prospects for regional cooperation. 
IV. THE WITHDRAWAL OF EDGARTOWN

The evolution of these regulatory powers, and the role of the Commission itself, has not taken place without stress. Clamor over the regional agency's exercise of their regulatory and general planning functions were commonplace. This is especially true when the Commission dealth with the more populated towns of Tisbury, Edgartown, and Oak Bluffs. Home rule sentiments seem to be the strongest among the residents of these towns, due, in part, to the well established local economies in each.

All three towns have taken votes to leave the Commission, usually as a result of dissatisfaction with the powers granted it by the enabling legislation. (see Appendix for ballot history). As of this date, two towns have fully withdrawn from the Commission: Edgartown and Tisbury. Ballot questions regarding the towns continued membership are non-binding. Once the town votes to leave the commission, it is up to the State Legislature to remove them by legislative act.

Edgartown's voters expressed their desire to leave the Commission at the annual town meeting in April of 1978.20 This was the result of a general fear and disdain for the regional body's ability to adopt regulations for DCPC's within the town's borders. The Commission's enabling legislation empowers it to adopt regulations for a town when it fails to submit it's own which conform to the guidelines developed for the district within a specified period of time (see Appendix: Chapter 637, Section 11, or Chapter 831, Section 10). These feelings were intensi- 
fied by the March 23, 1977 ruling of the Supreme Judicial Court of the Commonwealth in Island Properties, Inc. vs. Martha's Vineyard Commission. ${ }^{21}$ In effect, the decision meant that the Martha's Vineyard Commission cannot be limited by many of the state statutes which limit town regulatory boards.

On December 22, 1975, the Commission designated two Districts of Critical Planning conern as it is empowered to do in it's enabling legislation; the Island Road District and the Coastal District (see Map II). The Island Road District takes in a zone adjacent to or associated with the major roads of the entire island and a second zone related to special ways. Guidelines for these zones include regulations to allow for:

safe access and travel along the roads, protect the visual character and historic features along the roads, and maintain and enhance the state Road system. 22

The Coastal District is comprised of the entire coast line plus water bodies and wetlands bordering or feeding the coastal ponds. The goals of the district regulations are to:

prevent flood damage, maintain water quality and supply, prevent pollution, promote wildlife habitats, protect cultural and historic sites, protect the character of views, prevent damage to structures, land, and water as a result of erosion, and promote the development of the Island economy 23 
The legislation gives the towns up to one year to finalize their regulations in accordance with the district guidelines. 24 As was mentioned earlier, DCPC regulations must be adopted and administered by the towns as if they were part of their development ordinances and by-laws. 25

Residents and town officials were concerned that the extent of these regulations was not appropriate for Edgartown. There was some consternation that the town's ability to permit development would be limited since no permits may be issued in any DCPC unless it is in accordance with the regulations. 26

The reality that the MVC could adopt regulations for a town when it failed to submit them was perceived as a serious threat to home rule. For the first time in history, Edgartown residents would be obliged to abide by land use regulations which were not formulated by the town nor adopted at a town meeting vote. Edgartown voters were apprehensive of the regulations, and a special town meeting was held on December 2, 1976 to put the question of accepting these regulations before the voters. The people of Edgartown voted not to acdept these DCPC regulations adopted by the Commission. Realistically, it was not within the powers of the electorate to refuse the regulations. At this point in time, the Commission's legislation had no provisions for this kind of action on the part of the towns. 27 Edgartown, as a member town, was obliged to accept the regulations as called for by Chapter 637. All during the period after the nomination of the districts, it was obvious to the Commission that 
Edgartown would not readily accept any regulations so adopted. Coments from town residents indicated that the regulations might have no effect, since there would be no local enforcement of them. Generally, the residents were angry at this new "arrival", the Commission, which had sprung up in their midst.

Following it's legislative mandate, the Commission voted, on December 16, 1976, to adopt these district regulations for Edgartown. On December 21, 1976, these regulations became effective for the areas of the districts contained within Edgartown's borders. This vote caused a strong reaction among many of the town's influential taxpayers and selectmen who determined to remove the town from the regional agency.

Adding to these sentiments was the Island Properties decision. 28 This controversy was set in motion on October 25 , 1973 when Island Properties, Inc. began the formal process of getting approval for subdivision plans in the town of Oak Bluffs. This plan was for 850 building lots on 507 acres.

This development would be located in the vicinity of Sengekontacket Pond, a major tidal pond. As of October 25, 1973 , the Oak Bluffs by-laws prescribed a minimum lot size of 10,000 square feet. This proposed subdivision was within the limits established by the Oak Bluffs ordinance. On June 7, 1974, these plans were approved by the planning board.

Nearly two years later, on March 4, 1976, the Commission designated the Oak Bluffs Sengekontacket Pond District of 
Critical Planning Concern. 29 This district includes the lands and waters adjacent to sengekontacket Pond within Oak Bluffs. The density regulation for this district (if formally adopted) stated that:

the number of residential dwelling units which may be constructed and used or for which building and sanitary disposal facility permits may be issued shall not exceed one single family residential dwelling unit per 60,000 square feet of land area within the District. 30

This regulation would severely limit the number of units which Island Properties would be able to construct. Island Properties responded to this proposed regulation with a legal challenge based upon the state zoning enabling act. Section 7A of this act says that for seven years after filing a preliminary subdivision plan, a developer need comply only with zoning laws in effect when the plan is filed. 31 The district regulations were formally adopted on March 3, 1977. At the time of this decision, nearly 80 percent of the Island Properties subdivision remained unfinished.

On March 23, 1977, the supreme Judicial Court for the Commonwealth ruled that Island Properties, Inc. must comply with the more restrictive regulations of the Martha's Vineyard Commission. The court stated that the freeze of local zoning power under the sate zoning enabling act would apply to amendments by local authorities of the local zoning provisions. The freeze does not apply to actions of the Martha's Vineyard Commission which is authorized by state legislation and has 
regional scope and significance, regardless of the affect on local provisions. 32

Essentially, the Martha's Vineyard Commission received a strong stamp of judicial legitimacy. Reactions among Oak Bluffs residents and officials were generally supportive of this ruling as sengekontacket Pond was recognized as a fragile resource in need of protection. However, those Edgartown residents unhappy with the imposition of the DCPC regulations, realized the significance of this decision.

The powers of the Commission and it's regional purpose were recognized as superceding local authority. This came as no surprise to many Commission supporters, members, and staff. The state legislature had created the regional agency to accomplish the protection of the well defined region of Martha's Vineyard. It was created to handle problems and offer protection that the towns, acting independently, could not. Those Edgartown residents who wished the town out of the Commission, became very active politically, in hopes of ensuring their withdrawal.

Some of these individuals formed a citizens group known as "Citizens for Home Rule." Selectmen, realators, and other influential people were members of this organization. An active campaign was launched with bumper stickers, letter campaigns, public meetings, and editorial ads in the local papers. The goal was to place the question before the voters at the next annual town meeting in April, 1978 .

Supporters of the Commission responded to these efforts by forming an organization known as the "Edgartown Committee 
to Keep the Commission" and employed many of the same tactics as the "Citizens for Home Rule". The active campaigning by both groups was, at the least, successful in adding more registered voters to the local rolls. Apparently, many Edgartown residents were determined to have their voice heard and registered to vote on the upcoming ballot question. There were also some constructive efforts being made to change the Commission's enabling legislation. Proposals were made to the state legislature through the Natural Resources Committee and local representatives to effect changes in the act. Even before the Island Properties decision, the General Court of the Commonwealth had a number of bills before it aimed a changing the relationship between the towns and the Commission. Among these was a bill requesting that DCPC regulations be approved by a two-thirds vote at a town meeting before coming effective. ${ }^{33}$ This bill would also place enforcement of regulations promulgated by the MV in the regional agency's hands, and would hold the Commission liable for costs to the towns as a result of any of it's actions. Two other bills were submitted which would permit Edgartown and Oak Bluffs out of the Commission if the voters so desired. 34 These two bills were enacted into law on November 4,1977 . With these acts in place, it remained only for the voters to so decide, and Edgartown would be withdrawn.

Throughout this period, residents were reminded by the "Citizens for Home Rule" that the Commission had adopted regulations in spite of the wishes of the voters at the 
special town meeting in December, 1976. In mid-April, 1978 Edgartown residents voted to withdraw from the Martha's Vineyard Commission by casting their ballots in favor of the act of November, 1977. The vote was 675 in favor and 554 opposed. On July 1, 1978, the MVC no longer had any authority over any matter in Edgartown.

Almost immediately, the question was raised as to whether the regulation for the critical districts would remain in effect for the town after it's withdrawal. In the opinion of the Commission's legal counsel, the regulations were a part of the towns regulatory scheme and would remain in effect until the courts or the legislature decided otherwise. This opinion was made in light of the Island Properties ruling which held that the MVC regulations were not ordinary zoning, but bylaws that had been adopted by a regional body. Edgartown officials and residents wanted to know which regulations would be in effect after the July lst withdrawal date. It was the opinion of many officials, including selectmen, planning board members, and the building inspector that only the town's regulations would be in place since the town never adopted them and had rejected them at the special town meeting in 1976. The issue was to be decided by a legal challenge to the exercise of these regulations by the Edgartown planning board after the town's withdrawal!

In 1979, South Shore Trust, a Connecticut development firm, sought to create 28 half acre lots fronting two roads in Edgartown. This development was opposed by residents in the area and by officials of a neighboring airstrip. They 
said it would impede landing and takeoff patterns from the small airfield. The town planning board denied the application after finding that it did not meet the requirements in the Island Road District regulations that there be no more than one entrance from a road every 1,000 feet. In the South Shore Trust plan, there were driveway entrances every 200 feet.

Suit was brought to the Superior Court by John H. McCarthy, a trusteee of the development firm. ${ }^{35}$ There, a judge ruled that the Commission regulations were no longer in force in Edgartown and ordered the planning board to endorce the plans. The town appealed to the Supreme Judicial Court and here the ruling of the lower court was reversed. This court ruled that a town out of the Commission's jurisdiction may amend or rescind such regulations only through the identical process on which they were adopted, or by a separate, unilateral action of the town voters.

This decision settled the question of whether the Island Roads and Coastal District regulations were still in effect in Edgartown. It also provided the towns with a method of removing the regulations from their ordinances and by-laws. Only a town referendum was needed to relieve the town from the regulations adopted for them by the Martha's Vineyard Commission. This was accomplished at a special meeting held in April, 1981. By a very narrow margin, 234 in favor, 215 opposed, the regulations were stricken from Edgartown's by-laws. 
It is interesting to note how Edgartown, though ideologically opposed to such regulations, was willing to use them at their convenience. However, the convenience provided by these regulations no longer exists. Without them it is difficult to predict what success Edgartown will have on it's own managing growth in these unique and fragile areas.

\section{TISBURY AND THE STEAMSHIP AUTHORITY QUESTION}

Perhaps the most controversial and consequential decision of the Martha's Vineyard Commission, was that concerning the application of the Woods Hole, Martha's Vineyard, and Nantucket Steamship Authority (SSA) to construct an additional ferry slip on the south side of the existing terminal in Tisbury. Known as the "second slip" issue, it has raised as much concern and interest in island affairs as did the introduction of the Kennedy bill in 1972. 36

The Commission's relationship with Tisbury has been one of contradiction. Prior to 1980 , the town had already had four votes on it's continued membership in the commission. (see Appendix for ballot questions). The first vote occurred in 1976 over the town's dissatisfaction with the Commission's authority to adopt regulations for towns. Sentiments were not as strong in Tisbury as they were in Edgartown as the DCPC regulations were sanctioned by affirmative vote of the residents. The Commission survived this first ballot. 
In May 1977, a second vote was taken at the annual town meeting as anti-Commission sentiments increased in the wake of Edgartown's experience. The withdrawal was conditioned on the withdrawal of Edgartown and Oak Bluffs based on the DCPC issue. Since Oak Bluffs remained in the MVC, Tisbury was prompted to remain, even though the voters had expressed their desire to get out.

A third vote was taken in May, 1978. Again the voters desired to get out, but remained pending the adoption of certain amendments to the enabling legislation regarding the adoption of regulations. These amendments are discussed in the next section. One year after this, the voters elected to remain in the regional agency, apparently satisfied with the legislative changes.

Throughout this period, Tisbury cooperated with the Commission in developing regulations, CzM water quality planning, and systems planning. 37 Although there was precedent for controversy with Tisbury, the sensitivity of the town to decisions regarding Developments of Regional Impact had never really been tested. In August of 1977, the Steamship Authority had the Tisbury wharf surveyed and found that it had seriously deteriorated and was in need of reconstruction. John J. McCue, then general manager of the Authority, notified the Commission of these conditions and revealed their intentions to construct a second slip on the south side of the terminal as well as reconstructing the north slip. Mr. McCue explained that this slip would be used to ensure continued adequate service to the island in the 
event that the permanent slip was damaged or in need of maintenance. The cost of this project was an estimated $\$ 3,300,00 .^{38}$

The rationale for this proposal was based on the reality that the Oak Bluffs terminal, the only other port of entry for the SSA, is exposed on the open ocean side of the island, and, given winter sea and tide conditions, cannot be relied upon for continuous service. Thus, in the event of rough seas or unusually low tides, the Authority would be guaranteed a reliable port of entry (See Map III).

According to existing MVC criteria and standards, this proposal is a Development of Regional Imapct and the Commission prepared for it's consideration. 39 Before receiving the official notification, the agency was already fully aware of the Authority's intentions and consulted it's attorneys regarding the ability of the Commisson to regulate lands owned by the SSA. Three months before receiving the letter from Mr. McCue, the Commission was advised that these lands could be regulated by the agency. On the horizon loomed a conflict between two agencies; both created by state acts, and both created to serve the people of the vineyard. 40

The Woods Hole, Martha's Vineyard and Nantucket Steamship Authority was created as a corporate body on October 18 , 1960 "in order to provide adequate transportation of persons and necessities of life for the islands of Nantucket and Martha's Vineyard". The Steamship Authority consists of 


\section{MAP III}

STEAMSHIP AUTHORITY TERMINAL SITES

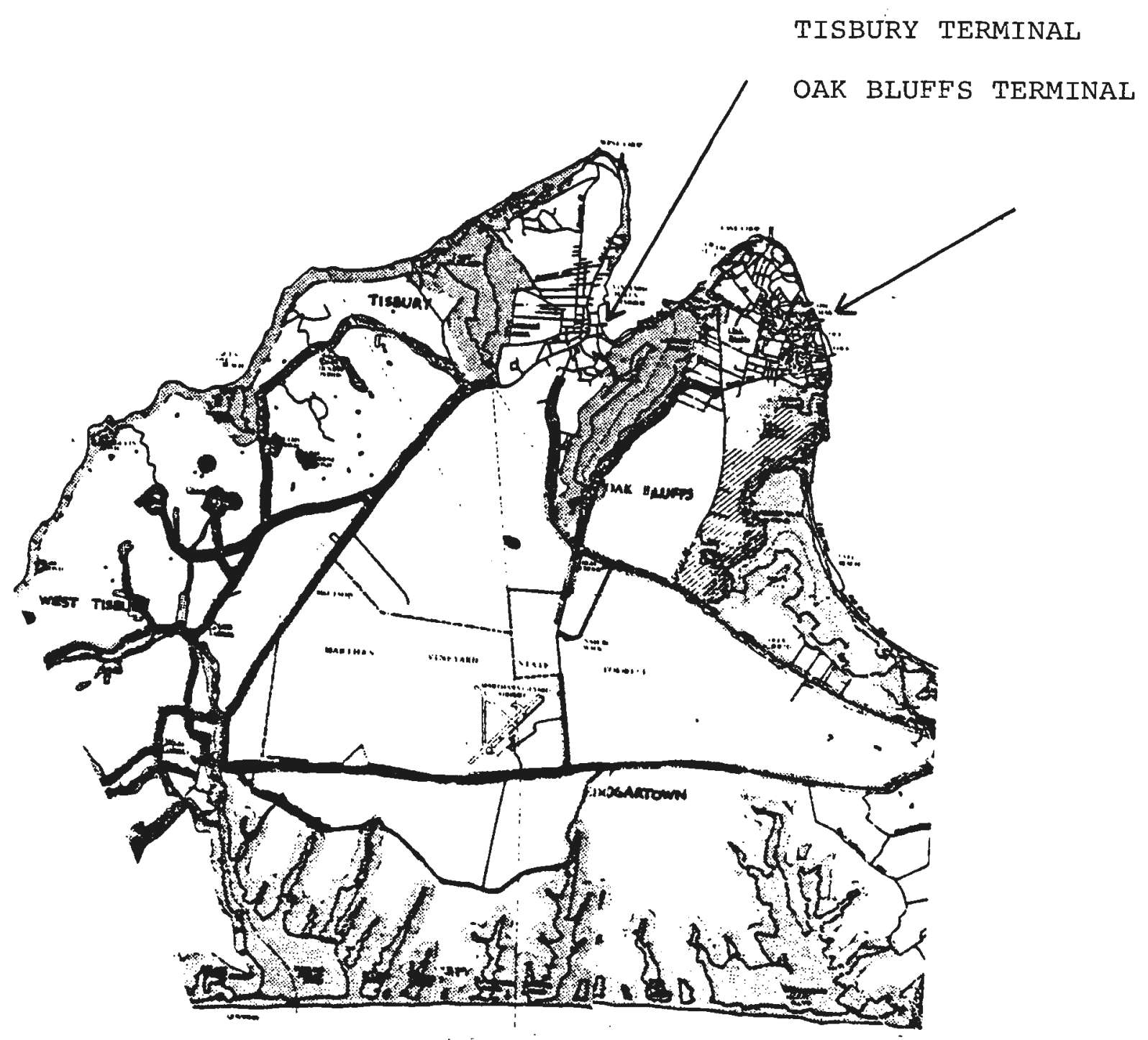


three members: one resident of the town of Nantucket appointed by the selectmen, one resident of Dukes County appointed by the county commissioners, and one resident of Falmouth appointed by the selectmen. In addition, the Authority retains the staff and employees of it's predecessor: the New Bedford, Woods Hole, Martha's Vineyard, and Nantucket Steamship Authority. 41

The purpose of creating an authority to perform a function which would normally be handled by an agency, board, department, commission, or office of the state bureaucracy seems to be to avoid the costly and complex web of legislative and executive controls needed to run the Authority. The Authority is also freer to act as a private business than a state agency would be. 42

This Authority was not, in purpose, any different from the previously existing New Bedford, Woods Hole, Martha's Vineyard, and Nantucket Steamship Authority. The New Bedford Authority was abolished and certain legislative changes were made as a result of legal challenges to the Authority. 43

Section 6 of the SSA enabling legislation provides that ....the exercies of the powers......will be in all respects for the benefit of the people of the commonwealth..... and.....the operation and maintenance of the steamship line by the Authority will constitute performance of essential governmental functions. 44

Section 19 of this same act states: All other general or special laws, or parts thereof, inconsistent herewith are hereby declared inapplicable to the 
provisions of this act. ${ }^{45}$

Based on these and other provisions of their legislation, the SSA felt it was clearly their right to construct a second slip with no interference from the Martha's Vineyard Commission.

On the other side, the MVC had good reason to be secure in the regulation of SSA owned land. In Section 2 of the Commission's enabling legislation, certain constituent entities of the Commonwealth are listed as being excluded from jurisdiction, including: agencies, boards, departments, commissions, or offices. There is no inclusion of authorities which is significant as there is sufficient legal precedent and case law in Massachusetts to consider authorities as separate legal entities. ${ }^{46}$

As discussed earlier, the Commission's regulatory powers are an attempt to deal with the complex problems of protecting the unique, natural, historical, ecological, scientific, cultural, and other values of the Island as well as promoting sound local economies. The Authority was created to protect the economic welfare of the island only by providing transportation. It was conceivable to the Commission, and other residents as well, that the Authority could sacrifice the unique values of the Vineyard when it was in their best economic or business interests to do so. ${ }^{47}$

Commission members saw this as an opportunity to get a handle on steamship Authority activities which would give the island some control over the number of visitors they would receive in the coming years. This is a key issue due 
primarily to the limited supplies of fresh water and the impacts of large numbers of visitors on septic and sewerage disposal systems. The application for the second slip set the stage for a policy conflict which was probably inevitable in the evolution of regional cooperation.

The town of Tisbury had recently been concerned with the condition and safety of the Beach Street, Water street intersection through which all vehicles unloading from SSA vessels must pass. In looking for ways to improve this (See Map IV) intersection, the town hired the firm of Alan M. Voorhees and Associates to study and recommend improvements. In June of 1978 , they released their report with this description of the intersection:

Streets, in the area of the terminal are narrow and almost rural in nature, with little, or no, curbing and/or shoulders. Travel demands placed on these streets and intersections are far above capacity, causing congestion with lengthy delays and hazardous operating conditions for both vehicles and pedestrians. 48

This report was noted by the Commission with concern for the possible impacts of two vessels unloading at once. Significant changes and improvements were recommended in this report including installation of a traffic signal, widening and improving roadways, and providing sidewalks. As of this writing, none of these recommendations have been implemented. 


\author{
MAP IV \\ BEACH STREET WATER STREET \\ INTERSECTION
}

TO TERMINAL

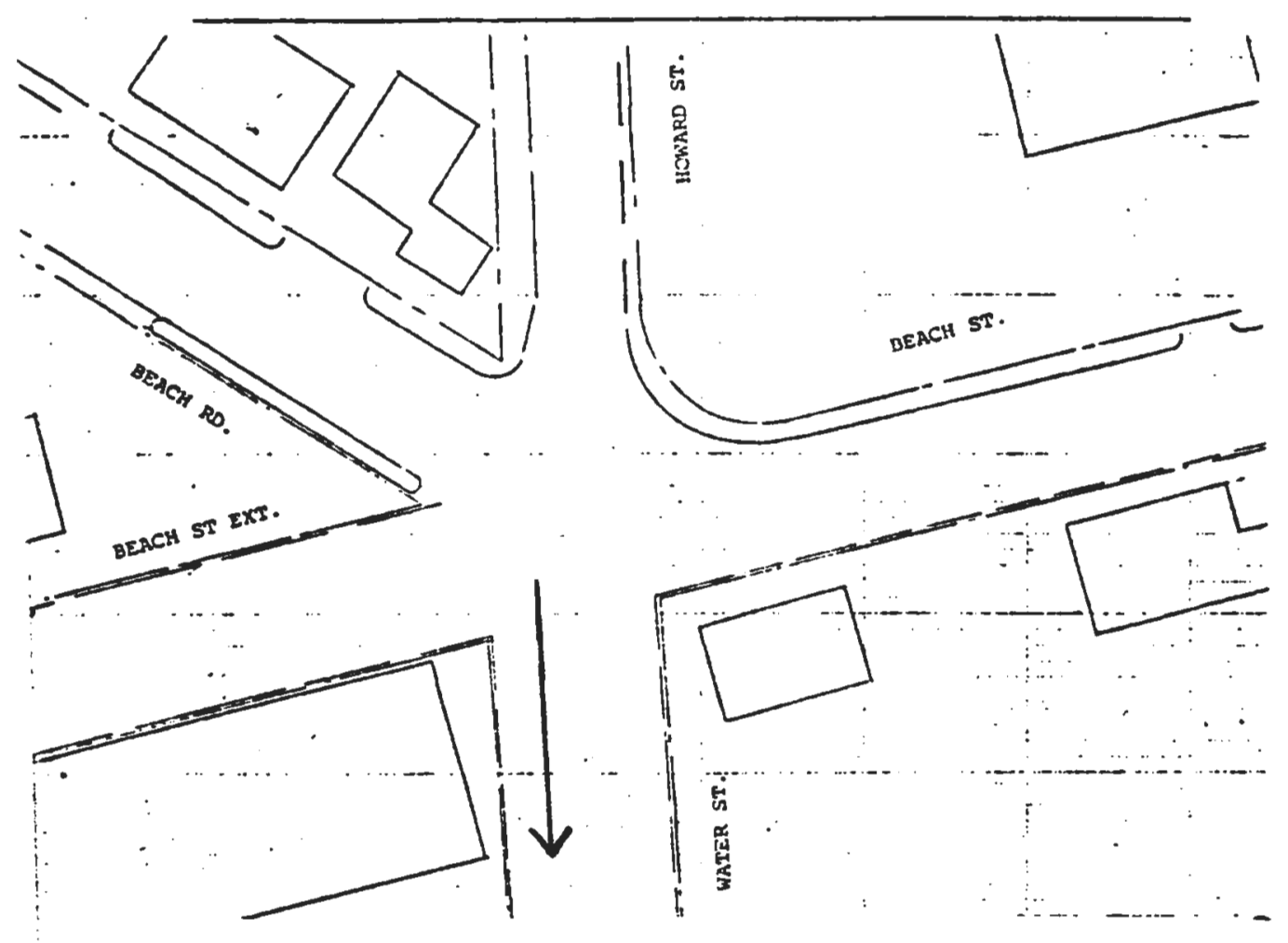

SOURCE: ALAN M. VOORHEES AND ASSOCIATES 
By December of 1978 , the SSA had completed it's plans for the project and filed a Notice of Intent with the Tisbury Conservation Commission as required by Massachusetts law. 49 The notice of intent described the project and it's potential environmental impacts as required by the accompanying Environmental Data Form. Specific project plans were also attached. 50

The Conservation Commission reviewed the form and plans and issued an Order of Conditions in February of 1979, which the SSA had to meet in order to proceed with the project. The conditions listed in this document are not a significant barrier to construction. Rather, they ensure that the environmental integrity was maintained according to minimum standards, and, that all procedures relating to the project as required by law were adhered to. 51 The Conservation Commission looks at a narrow definition of environmental impact. Although the SSA was required to provide information on surface water, topography, ground cover, soils, surface water, waste, and capacity, very little detail was required as to the specific impacts of the projects. Since the application was for a development within a harbor, in a water body of ten or more acres, a development within the ocean, for the reconstruction/construction of a facility designed to serve the residents of more than one town, and would provide facilities for transportation to or from Martha's Vineyard, it is a Development of Regional Impact. The Tisbury Conservation Commission noted this and duly referred the application to the MVC as required by the 
enabling legislation. 52

This application was received by the MVC on March 22,1979. Consideration of the project was well underway before this time, however. In fact, on February 14, 1979, the Joint Transportation Committee, consisting of Commission staff and other individuals, had recommended approval of the complete SSA proposal. This recommendation included the condition that there would not be a decrease in the utilization of the Oak Bluffs facility, increase in the utilization of the vineyard Haven terminal during the summer season.

On April 19, 1979, members of the Commission and it's staff visited the site and inspected the deteriorated condition of the wharf. Later that same night a public hearing was held in accordance with the enabling legislation where the official engineering report was reviewed. In addition, Mr. McCue gave assurances that the authority had no intention of increasing the level of service for the Island beyond that of the 1978 level, and stated that he would be pleased to place this condition in writing. Opponent of the proposal also testified and raised questions as to the impacts the second slip would have on the Beach street, Water street intersection.

At a regular Commission meeting on April 26, 1979, students from the Harvard Graduate School of Design made a presentation concerning the impacts of the proposal. In late 1978, the Commission had been contacted by this student workshop group with the intention of studying the development's impacts, trends in island travel, passenger volumes, auto 
volumes, employment, expenditures, auto accumulation on the island, and scheduling and fleet composition. The main conclusion of this group was that the ferry fleet was at seasonal capacity for automobiles and at 70 percent capacity for passengers and condluded that there was no impact from a second slip given the present fleet composition. 53

On May 3, 1979, after extensive discussion, the Commission voted to approve the complete proposal of the SSA to build a second slip while reconstructing the existing slip. However, one week later, the Commission reconsidered it's May 3rd decision. They aqain studied the issues of auto and pedestrian traffic volumes, financing of the project, including assessment of reconstruction costs against the island communities in the event of the SSA's deficit, and the regional economic impacts resulting from potential increases in traffic. Of particular concern was the possibility that the Authority would be pressured from an increased demand to increase the level of service beyond the 1978 level, regardless of Mr. McCue's assurances.

Representatives from the Tisbury Board of Selectmen were also present at this meeting and indicated that they were divided over the proposal. A representative from the Oak Bluffs board indicated that they had voted unanimously in opposition to the two slip proposal. This vote was made with grave concern for the long-term economic vitality of Oak Bluffs which is largely dependent on it's share of the seasonal traffic. Any interruption or decrease in the numbers of visitors to Oak Bluffs would have adverse effects on it's economy . 
The Commission reconsidered it's vote and on May 10 th voted to allow the reconstruction of the existing slip and not to allow the construction of a second slip. 54 Applying the standards of probable benefits against detriments, the commission based it's decision on three primary considerations: 55 1) a single slip will insure that Oak Bluffs would continue to receive 12 percent of seasonal traffic and remain economically viable, 2) a single slip will insure that Vineyard Haven (Tisbury) traffic conditions will not further degenerate, especially in the locus of the Beach Street, Water street intersection, 3) a concern that furture demand increase auto and pedestrian traffic to the island.

In addition to these considerations, the Commission further noted that one slip would remain idle for at least nine months of the year and found that this was not a wise use of public funds. Since the people of Martha's Vineyard are responsible for deficit spending by the SSA, and Dukes County has the lowest per capita income of any other county in the Commonwealth, there was concern that the people could not sustain any extra financing burden which might be imposed upon them. (The complete text of this decision can be found the the Appendix). The Commission saw that it's decision to allow only one slip would not interfere with the economy of Tisbury or the region, hence protecting and promoting sound local economies as mandated in the legislation.

Events moved quickly after the reversal of the original decision. Two weeks after the MVC rejected the SSA proposal, 
the steamship line put forward a plan to the MVC which would allow it to go ahead with the construction of the second slip, after agreeing to certain self-imposed conditions. These conditions were designed in hopes of satisfying the concerns of the MVC (see Appendix for full text). 56

In summary, the Authority would not use the second slip to expand service to Tisbury at the expense of traffic to Oak Bluffs. It would be used to avoid delays when Oak Bluffs was not usable, service ferry traffic while the first slip being reconstructed, and to service a vessel when the primary slip was occupied in order not to inconvenience patrons on board. This plan would also permit the Authority complete flexibility and authority to make any changes in the conditions if it deemed them appropriate.

In conjunction with the proposed compromise plan, the SSA also filed an appeal to the decision in Suffolk Superior Court with the hopes that their perceived rights to run the boatline would persevere in court, and that meaningful negotiations would be stimulated between the two bodies.

The sticking point to the compromise plan from the Commission's viewpoint was the ninth proposed condition which reserved the right of the Authority to make decisions in unexpected or emergency situations as it saw fit.

During this period, the Authority received letters and petitions of support from the Tisbury Business Association, the Vineyard Chamber of Commerce, and the Edgartown Board of Trade. The Tisbury Association also circulated petitions and sent letters to the Tisbury selectmen demanding that the 
Commission accept the second slip.

Leaders of this association and John L. Schilling, chairman of the Tisbury selectmen were now saying that the real issue was not just the second slip, but home rule. It was their opinion that the second slip was necessary to the continued economic health of the island and that the Commissions decision hurt economic growth by impairing the Authority's ability to operate.

At an open meeting on July 11, 1979, the MVC was accused of threatening economic growth by interfering with the island's link to the mainland. Ronald Mechur, then executive director of the regional body, explained that the decision was not an attempt to stifle business, and the Commission was not actually opposed to the slip itself. He added that it was the ninth condition of the Authority's compromise that was holding the two sides apart. The agency was requesting that the authority submit any service expansion proposals for Commission approval which the Steamship Authority was not willing to do. It was the Commission's view that one means of promoting a sound economy on the island is to make reasonable restrictions on the major transportation development on or to the vineyard.

A spokesman for the SSA countered that the Authority could not relenquish the right to govern it's own situation as provided in it's enabling legislation.

In October 1979, the SSA voted to begin, no later than January 1, 1980, the construction of a standby slip at Vineyard Haven and full reconstruction of the existing slip. 
This standby slip, which would be constructed first, would be torn down if the MVC were to win the litigation which had been moved to the state supreme Court in order to decide the broader question of authority and not merely the wisdom of the decision.

One month later, the MVC voted unanimously to reject this proposal, despite the assurances of the Authority that the slip would be dismantled if the Commission won the litigation. This did not, however, close the door on any construction at the terminal. There was still the possibility that the Authority could submit the proposal to build a new south side slip as a DRI, go through the hearing process, and construct the slip. However, this would only be allowed if the authority proceeded to demolish the existing north slip.

This decision meant that the SSA could only do emergency repairs to the north slip which necessitated it's closing. It was probably the only realistic choice the authority had at this time in wake of the Commission's decision to reject their latest proposal. The Authority announced that the terminal would be closed sometime in March and could remain so into July, which could have been disastrous for the 1980 summer season.

Reactions from residents were strong, particularly among members of the business community as this could mean economic disaster. Some individuals claimed shortsightedness on the part of the Commission, others talked of a power play and scare tactics by boatline officials. The latter reaction was 
most evident after the Authority announced it would be willing to consider a reversal of their decision if the Commission would accept their compromise and allow a second slip pending the outcome of the litigation.

The vote against the compromise second slip proposal was done at the request of the Commission's attorney, who advised that accepting the proposal would compromise the litigation before the Supreme court. Accepting the proposal would overlook the legal question of the agency's ability to regulate SSA owned lands.

Private citizens and members of the Chamber of Commerce issued pleas to both sides to compromise. The SSA was urged to resubmit it's compromise proposal as a DRI, and the Commission was urged to approve and adopt the new plan. Emotions were running high among many residents of Martha's Vineyard.

Seeking to avoid economic diaster, the MVC met shortly after the SSA announcement to close the terminal and voted to hold a public hearing to amend the original agency decision of June 7, 1979, allowing only one slip. The amendments would allow the construction of the south slip so long as the existing slip was not used once the new one was readied for operation.

While the MVC was willing to consider this as a compromise, the Steamship Authority would not allow any strings to be attached to it's operations. Alfred F. Ferro, the Vineyard representative on the SSA, announced that he would 
urge the boatline to continue it's plans to close and rebuild the existing Tisbury slip. (The Vineyard is represented on the Steamship Authority by an Islander who is appointed without compensation by the County Commissioners) . He firmly expressed his belief that the boatline should be free to act as it chooses, and saw any encroachment on that freedom as a threat to the line's solvency and, hence, a threat to the Vineyard. The SSA apparently equates it's own economic good with that of Martha's Vineyard which is quite reasonable. At issue was whether the denial of a second slip posed a threat to their econmic well being. At the subsequent public hearing in January 1980, the MVC unanimously voted to allow the construction of the second slip, provided the boatline did not use both ferry slips before the court decision was rendered in the litigation between the two bodies.

Reacting negatively, and in the expected manner, the SSA quickly voted to approve plans to repair the existing slip, closing it for up to six weeks. The commission compromise was not acceptable.

Essentially, the compromise amendment to the orignal DRI decision was not really an addition. It was consistent with the original decision in that it would allow only one slip to be used at any time. The original decision permitted only reconstruction of the existing slip; the amendment would permit one slip on either side of the wharf.

Fearing severe economic consequences and perhaps resentful of the MVC's handling of local affairs, some 
Tisbury voters began moving for the towns withdrawal from the agency. The Commission immediately recognized the unhealthy fiscal position this would place them in. Aside from losing the town's annual assessment, certain federal and state funding programs which base their support on the population served might be lost. The MVC also recognized that changes in the enabling legislation would also be necessary. Negotiations with Edgartown were already in progress as to proposed changes and it's re-entry into the agency.

In seeking to draw the support of Tisbury voters, the Authority published a full page "white paper" in the Vineyard Gazette entitled "An Open Letter To All Vineyard Families" which detailed the controversy from the boatline's point of view. This "white paper' was a rather slanted account of the events here recounted and had to have some effects in discrediting the agency. ${ }^{57}$ The timing of this letter shortly after talk of Tisbury's possible withdrawal is no coincidence. If the town was to withdraw at the urging of the voters, the DRI decision would no longer be in effect, contrary to DCPC regulations which become part of the local ordinances.

Admid all of this political storm, the vineyard Haven terminal was temporarily closed for repairs in March, leaving the Vineyard dependent on the Oak Bluffs facility. on the same day as the closing, the Tisbury selectmen voted two to one to refuse to sponsor a petition which would put the town's membership in the regional agency to a vote. This forced the petitioners to gather 186 signatures (10 percent 
of the electorate) for a non-binding question which would appear on the May ballot.

The question of Tisbury's future was placed directly in the hands of the voters. Implicit in this question was the future of the Martha's Vineyard Commission and the unique regulatory umbrella it provides. Should Tisbury withdraw, Oak Bluffs might be unwilling to bear the burden of funding the MVC, as they would be the only remaining town with a large population. While all assessments would be increased, Oak Bluffs would bear the heaviest load and should they withdraw as a result, the MVC would probably cease to exist.

With the inevitability of a ballot question, both sides campaigned actively to get the support of the voters. News conferences, letters to the editor, an open house, and a letter campaign by the League of Women voters were used to gain support and reduce fear and animosity directed at the commission.

The Steamship Authority's prodding of Tisbury voters was aided by a near disaster when the MV Islander, one of the authority's vessels, ripped it's hull open on a rock after leaving Oak Bluffs on March 19, and nearly sank in rough seas. While no one was seriously injured, the event stunned island residents and provided the SSA with a convincing, though disputably argument for their proposal to build two slips.

On Thursday, May 8, 1980, the Town of Tisbury voted 
556 to 378 to withdraw from the Martha's Vineyard Commission. 58 While the recent disruptions in service, the near disaster of the Islander, and the inclement weather which kept the turnout low contributed to the Commission's defeat, the true reason may be laid to broader issues. Anger at the agency's handling of the second Tisbury slip, dissatisfaction with Commission members and local selectmen also contributed. Perhaps the most important reason was the local perception that the Commission's powers supercede home rule perogatives. The precedent for this feeling has already been mentioned with regards to Tisbury and the withdrawal of Edgartown. The twofold regulatory powers of the Martha's Vineyard Commission had resulted in the withdrawal of two member towns. The evolution of these powers was fostered out of a critical event.

The result of the vote meant that a bill would go to the state legislature authorizing the town's removal from the Commission by July 1, 1980. This bill was unanimously endorsed by the Tisbury selectmen who, politically speaking, had no choice but to honor the wishes of the voters. 59 On June 4, 1980 the State Supreme Judicial Court ruled that the Martha's Vineyard Commission has the power to regulate Steamship Authority developments on the Martha's Vineyard, 60 and that Commission was acting within it's legal authority when it considered the second slip. While the ruling did not deal with the specific merits of the DRI decision, the ruling strongly affirmed the regional agency's right to regulate development. 
This decision, on it's face, appears somewhat hollow from the commission's point of view. However, it came during a time when negotiations with the towns over legislative reforms were beginning and this gave the agency legitimacy going into this process. It also provided the agency and the people of Martha's Vineyard with more power over things which have an impact on the island. In addition, the decision clearly defined the limits of the SSA and formed the basis for a more workable relationship between the two agencies. In keeping with the wishes of the voters of Tisbury, the town was allowed by the state legislature to withdraw from the MVC on July 1, 1980. Aside from the fiscal impacts on the agency, it remained unclear whether or not Tisbury's withdrawal would mean that the SSA could proceed, without Commission regulation, to build a second slip. The Authority had full intentions of pursuing this course and noted with interest the outcome of a suit by Gregory E. Carter, who had been refused the right to receive building permits in a DRI decision when Edgartown was a member. When Edagrtown withdrew, Mr. Carter sued for permits for 15 lots of a Chappaquiddick subdivision and won. 61

There seemed to be sufficient legal precedent, but the Authority was not convinced as the Commission offered no challenge to the Carter suit with Edgartown out of the agency. Realizing that sentiments were still very strong on both sides, and fearing a third party suit based on the original DRI decision, the SSA decided to refile the application with the Conservation Commission. The Conservation Commission 
issued permits with a statement of concern regarding the potential increases in service to vineyard Haven and the resultant impacts.

While awaiting the final permits from the Tisbury Planning Board, two appeal petitions of the Conservation Commission permits were formally filed with the Massachusetts Department of Environmental Quality Engineering. One petition was signed by five Oak Bluffs residents, and the other was signed by ten Tisbury residents. The appeals contended that the Martha's Vineyard Commission's original DRI decision was still binding and that the Tisbury Conservation Commission acted improperly by issuing an order of conditions and permits allowing the project. The signers were seeking a commitment from the Authority of no increase in Tisbury service beyond the 1978 levels, and no decrease in service to Oak Bluffs. DEQE would have to hold a hearing on the appeal, and rule on whether or not the order of conditions was issued properly.

These appeals were a potential problem for the MVC as there were fears that such delays could harm the negotiations beginning with representatives from the six towns regarding agency reforms. Both agencies, the SSA and MVC, opened communications in an effort to find an emenable solution to the potential effects of these appeals. These actions could force the Authority to abandon it's plans to begin work on the second slip.

Not willing to wait for the outcome of the appeals, the SSA issued bonds and ordered materials for the two-slip project. In November 1980, the DEQE dismissed the appeals, 
55

clearing the way for the project's completion.

The MVC and the SSA discussed the possibility of

reforms in the agency's enabling legislation which would

provide an appeals process. These, and other changes in

the legislation resulting from these events will be discussed

later. As of this writing, the SSA had moved to file a bill

in the state legislature to remove the boat line from the jurisdiction of the Martha's Vineyard Commission. Also, on

a recent visit to the Vineyard the author noticed that substantial progress had been made on the construction of the second slip. 


\section{THE EVOLVING LEGISLATION}

The legislation creating the Martha's Vineyard Commission has undergone significant changes since it was enacted. These changes are embodied in Chapter 831 of the General Laws enacted in 1977 as amended by 1979 Massachusetts Acts, Chapter 319. This amended version of Chapter 637 is in effect today, yet, will in all probability, be amended in the near future. 62

The key issue in amending the original legislation was the Commission's ability to adopt regulations for a town without it's approval. Oak Bluffs, Edgartown, and Tisbury had already demonstrated their concern over this issue by placing their continued tenure in the Commission in the hands of the voters. Throughout it's existence, the commission has been faced with the possibility of a reduction of it's regulatory authority.

Various bills have been introduced to the state legislature on behalf of the member towns, and also by the Commission itself. The withdrawal of Edgartown and the possibility that Tisbury and Oak Bluffs would follow over the DCPC issue stimulated serious negotiation. A key actor who initiated many of the changes which are contained in Chapter 831 , was former Massachusetts Representative Terrence P. McCarthy. While representing Martha's Vineyard, and later as Vineyard liason for Representative Howard C. Cahoon Jr., Mr. McCarthy worked with state and local officials, local interest groups, and the MVC to negotiate changes in the act. He recognized the potential value of the regional agency if the bill was 
amended to satisfy the desires of the towns without a total sacrifice of it's regulatory authority.

The negotiating process may be viewed as an attempt to strike a balance between those in favor of the Commission's regulatory authority and those opposed to any interference with home rule perogatives. Strong support for regulation may be found in the towns of Gay Head, Chilmark, and West Tisbury. 63 This is due, in part, to their desire to have their large inventories of open space protected from intrusive development. It is also due to their lack of authority and resources to regulate these areas as they wish. The unique regulatory powers of the MVC can accomplish far more in the way of regional environmental protection than local zoning ordinances. Edgartown, Oak Bluffs, and Tisbury are far more urbanized and have well established local economies. The protection and development of these local economies is very important to the local business communities. While growth management remains an important issue in these towns, it is the opinion of many community leaders that it is often done at the expense of the local economies and supercedes local authority. Many members of the business communities of these towns favor a return to an advisory agency such as the Dukes County Planning and Economic Development Commission.

Various solutions have been offered to achieve this "balance." Presented here are specific changes that were made to Chapters 637 and 831 as a result of the negotiating process previously mentioned. While some of the amendments were made to make the legislation better outside of the 
focus of land use law, most were made to eliminate further controversy over the adoption of DCPC regulations.

Originally, the Commission member appointed by the selectmen of each town had to be selectmen or a member of a local municipal board or agency. The amended version allows any resident who is registered voter to be appointed to a Commission seat. 64 This decreases the chances of a conflict of interest between the decisions of the commission and what strong local interest groups may favor. It, in effect, reduces the political focus of many Commission decisions.

Chapter 637 authorized the Commision to transfer monies from it's accounts to any town agency when that agency has incumbered a cost in it's enforcement of DCPC regulations. This act also permits the Commission to accept gifts of, or interests in land, and accept contributions for acquisition. These two provisions have been stricken from the act in it's amended form. 65

Chapter 831 clarifies the method for determining the assessment to be paid by each town. This amount is stated as not to exceed .036 percent of the latest equalized valuation for property tax in each town with a penalty of eight percent per annum to be added if the towns do not pay within sixty days of notification. The original act contained no specific percentage, leaving the assessment open to debate. It also left open the possibility that a town's assessment could be increased to make up for the loss of another's due to it's withdrawal. 66 Further, Chapter 831 states that where there is a conflict between local ordinances and Commission 
regulations, the more limiting regulation shall prevail. This tends to clarify the Commission's regulatory role as their regulations are generally more restrictive than those enacted locally. 67

Under Chapter 637 , a petition of twenty-five taxpayers from any island town could have nominated a DCPC for designation in addition to the Commission, selectmen, or appropriate town boards. This was chanced to a petition of seventy-five island taxpayers, perhaps to ensure a more broad based approach to nomination and to avoid indiscriminant actions by small interest groups. 68

The amended legislation does much to clarify the role of the towns in developing regulations in conformance with the guidelines developed by the Commission for DCPC's. In Chapter 637, no mention was made as to what municipal agencies or boards would be responsible for developing these regulations. Chapter 831 specifically provides that the local planning board, board of health, board of selectmen, and conservation commission shall prepare proposed regulations. This helps to alleviate the tensions resulting from the Commission acting alone when formulating appropriate regulations. It also provides an opportunity for town residents to identify with the regulations as they are developed by their own local boards. This acts to change the perception that the regulations are being imposed on a town instead of the more palatable local formula. 69 Further, Chapter 831 extends the time period for local formulation from three months to six, giving the towns more time and flexibility. 70 
The power of the Commission to adopt regulations for a town was retained in the amended legislation. However, the process of amending or rescinding the regulations was clarified. Under Chapter 637 , no specific process was provided. It was only stated that it be in accordance with the manner provided for adoption and approval. This was vague and contributed to the confrontation with Edgartown. Chapter 831 is very specific in providing a process to amend or rescind the regulations. 71

The process begins with a written request by one of the four town boards mentioned above, a petition of seventyfive island taxpayers, or the Commission. This is followed by a public hearing by all four of the town boards where a recommendation is formed with input of local residents. This recommendation is transmitted to the Commission who holds another public hearing to form a recommendation of it's own which is transmitted to the town. Ultimately, the question will appear on the town ballot where the regulations may be rescinded or amended by a two-thirds vote of the member town after appropriate discussion on the town floor. If the voters decide against the regulations, they are rescinded immediately. Thus, a method for the towns to veto regulations was written into the legislation. It is interesting to note that many of these changes were proposed before Edgartown's withdrawal, but were not sufficient to mollify the sentiments of the voters. The withdrawal of Edgartown was perhaps a function of bad taste left over from the Commission's overturning of a town meeting vote. It was also 
FIGURE II

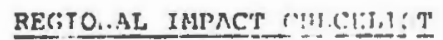

VOTED BY TIE MARTIA'S VINEYARD COBMISSION on $1 \% / 21 / 76$

И.-

\section{$1.00 \quad$ PREMMII,E}

is mandated by Chapter 331, as amended, of the Nets of 1977 and pursuant to irtiole 49 of the consitution of the conmonricillh of hassachusctes, it is the intent of those provisions to proviln for the rrotection of the health, safety anil general welfaro of Island lnsiconts arst visitnrs. The checklist will be used to designas" deviluments of regional ispact to be processed by the Comisisicn to prosurve sur ruhance the n., t.: ral, historical, ecological, scientific, cultural, and obher specin! values

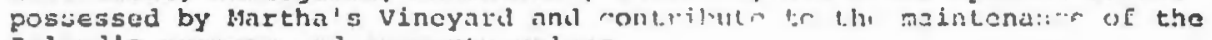
Islaild's cconomy and properly valliss.

\subsection{DEFIIITIO::S}

2.10 "Development" seans any builuine, midilu, dredjing, idiling, excavation, or drilling: or nny muturial change in t:w $1: 3 e$ or

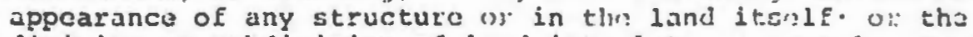
division or subdivision of Jitnd jnto lots or pare 1.3; or a change in the intensity of uss of the land, such 2:0 at jilcrease in the number of unit:s in a structuge; of al betation of a shore, beach, scacoajt, =iver, strean, laje, pois, or conal, including coastal constructinu; or denolition ef a structure; or the deposit of refuse, solic or lifulis :atste or Eill on a nazcel of land; or as otherwise derines in this checklist.

2.20 "Floor area" Includes total cuclo:ici floor area of i:ll f?nors. For additions of auxiliary buldinys the bloor ares i. c?u. =? the floot area of any now strieture: as woll as the cisisting strusture(s).

$2.3 n$ "Outcioor coinercial space" incluelng total arca uses far clisplay, dolivery, loading, storate, seles, p'nduction, parting and processiny exclusivo of access roads and.exclusion of the "Eloor aria".

2.40 "Private rucreational facility" includes privately onond recreational Eacilities used liy mujtiple housuhulds on a regular basis.

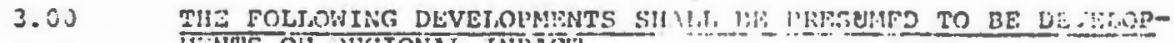

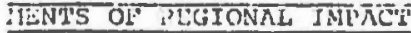

3.10 il1 Develonments:

?.101 Any development, with tile conct: rence of the itartha': Vineyard Commission, which ig bithin ond tuwn and which s state agency or the plannims Loard, crnservation conmiss', b'ard of health, or selectmen of another town his requested be designated a developuent of rerinnal linpact. In convurring with such a desiynation, the partha's Vinuyard Comizision shall Eind that the ptoposed lovengemont fulfllls at least cne of the consideratiuns in section 13 of Chapter $3,1 \mathrm{~L}$, as amended, of the ncts of 1277 . 
3.102 within a critical planning ni!strict, any dovelorment which qualifies according to this cliceklist and has not bnen specifically excluded by the connission, plus any development which the Commission has specinlly classified : being of reglonal impact.

3.20 Divisions of Land:

3.201 Any development which proposes to divide a contiguous ownership of more than 30 acres into 4 or murc lots.

3.202 Any development which proposer to divide a contlguous ownership of more than 15 acres, if such parcel has been $\approx$ ibdivided, or nart of a division thought not to require approval, In the last seven years.

3.203 Any development which proposes to divide a contiguous onnership of land into 10 or more lots.

3.30 Commercial Business and Industrial Develoment:

Any proposed retail or wholesalc business, offlce and/or industrial development, as well as any private recreational or educational facility which has a floor area greater than 3,000 square feet and/or outdoor commercial space grater than 6,000 square fect.

3.40 R.esidential Construction

Any roposed residential development, incluling the crpansion 0 existing developments, that is planned tu create or accommosate more than 10 dwelling units.

350 Develoument in the Harbors, Great runls, or: Dcean

3.501 Any development proposed within Edgartown, Vineyaró ll.3veu, Aenemsha, or Oak Bluffs Harbors.

3.502 Any development proposed within a water body of 10 acres or more, or within the ocean.

3.60 Public Facilities

Any health, educational, recreational, governmental, or other publicly nwred or quasi-publicly owned facility designad to serve the resiclents of more than one tuwn.

3. -0 Transportation Facilities

3.701 Any develupment the proposed construction or expansion of which will provide facilities for transportation to or frof Martha's vineyard.

3.702 iny development the proposed construction or expansion of which will be part of an internal regional transportation system.

3.703 As used in sections 3.701 and $3.70 \%$, the term "development" shall rofer to facilities for com:"rsinl and public transportation by air, land and whter, and rha! include but r.st be linited to rtinidy, terminals, incts, roads, and routo.. 
perhaps, perceived as the only way the town could realistically negotiate with the MVC.

These were the major changes to the legislation made out of the experience of adopting DCPC regulations for a town. The potential impacts of the DRI decision concerning the second Tisbury slip were not yet foreseen. Previous to and after the withdrawal of Tisbury, the DRI process was being reviewed for proposed changes by representatives from all six towns, the All Island Selectmen's Association and the Commission. Michael Wild, the Commission's executive director, was particularly active in this negotiating process.

Presently, the proposed amendments to the DRI process are undergoing further revisions. ${ }^{72}$ Generally, the intent is to have more discretion for the towns as to the developments which will be referred to the Commission for approval, disapproval, or approval with conditions. Also being proposed are a mediation process and a procedure for towns to withdraw and rejoin the Commission.

It is significant to this discussion to note that the standards and criteria used to identify Development of Regional Impact became amendable under Chapter 831. Chapter 637 made no mention of any process by which these standards and criteria could be changed once adopted. The process provided for by Chapter 831 allows for a public hearing and considerable input from local board's and agencies. ${ }^{73}$

According to Chapters 637 and 831, certain types of development are automatically considered as DRI's (see Figure II). ${ }^{74}$ A draft of proposed changes as of November 1980 reduces the 
AUTOMATIC :

1. Subdivision of ten lots or more.

2. Any solid waste disposal facility.

3. Any hazardous waste disposal facility.

TOWN DISCRETION :

1. Commercial development of 3,000 square feet or more.

2. Outdoor commercial development of 6,000 or more square feet.

3. Residential dwelling units of ten or more.

4. Development in any harbor.

5. Development within a waterbody of ten or more acres.

6. Development within the ocean.

7. Public facility serving more than one town.

8. Transportation facility to and from the Vineyard.

9. Regional or island-wide transportation facility.

10. Subdivision of four or more lots with a total area of 30 or more acres.

CROSS TOWN REFERRAL:

1. One town may refer a development with the above conditions occurring in another town.

FIGURE IV PROROSED TOWN DRI REFERRAL PROCESS

1. Applicant submits project to appropriate permit granting board within town.

2. In house review by permit granting board and selectmen. A concurrence, by majority vote of each board, that it may be a DRI triggers a public hearing. If there is no concurrence, then the project is not a DRI.

3. Public hearing with 14 days notice. If both boards concur, project is referred to commission. If not, then no referral is made.

A. Public notice of a brief written statement of decision within 10 days after hearing by one or both boards.

B. Date of notice triggers a 14 day period for possible petition override by $25 \%$ of the affected town voters.

C. Commission must concur.

4. Review by commission. 
FIGURE V NECESSARY STEPS TO MEDIATION

A. Parties must agree to mediate (could be more then two parties).

1. Initiation: By applicant request and "yes" vote by at least two commission members within 20 days after the decision.

2. Withdrawal: By unilateral action of either party upon written notice. Receipt of notice starts the 20 day period for appeal to superior court.

3. Limitations: Only automatic or major DRI's are open to mediation. Major DRI decisions are made by a majority vote of the commission membership.

B. Mediator chosen by mutual agreement between the parties, by state agency, local boards, and Commission.

1. Mediator must be respected, and known by all actors in the process.

2. Ground Rules: Meetings, spokespersons, clarifying issues, sequencing, and news releases must all be part of the process.

FIGURE VI REJOINING/WITHDRAWAL

A. Rejoining Process

1. Town ballot vote spring 1981, majority vote to rejoing with assessment vote on commission services to start July 1 .

2. Interim town representation.

3. Two year commitment.

B. Withdrawal Process

1. Annual town meeting, 2/3 vote to withdraw.

2. Timing delay to assure budget and contract transition for commission.

3. Mediation process initiated between vote out and actual withdrawal. 
number of automatic referrals to three and places most of the referrals at the discretion of the towns (see Figure III). A process whereby town discretion and referral is accomplished has also been proposed (see Figure IV).

The mediation process, as shown by Figure V, was proposed to give the MVC a method of negotiating decisions without the necessity of going to the courts or losing another member town. Mediation seems to be an appropriate process to alleviate the crisis atmosphere surrounding most of the disagreements. This process acknowledges that both sides have legitimate claims, and avoids having one big winner and one big loser as is usually the case with a costly court battle or binding arbitration. It provides a healing process which seems to be essential to the survival of the MVC. 75

One may only speculate that Edgartown and Tisbury would have remained in the Commission with a meaningful mediation process, yet it is probably true that many of the bad feelings resulting from the events furrounding their withdrawal would have been avoided. Providing towns with processes to withdraw and rejoin the Commission (see Figure VI), may have made the original act a more complete piece of legislation. Without these, the towns had to rely on the legislature to enact special laws which permitted them to leave.

One must be cautious not te be overly critical of the original act based on hindsight. Yet, if one views the MVC as a pilot organization, there are obvious lessons to be gleaned from the regional agency's experiences. These lessons should be considered when applying a similar regulatory scenario 
elsewhere.

VII. ON REFLECTION

It is unfortunate that the Martha's Vineyard Commission had to undergo fundamental changes as a result of confrontation. As a pilot piece of land use legislation, it lacked the sensitivity to the unique environment it was developed for. Even with extensive citizen input into it's creation, the legislation was inadequate for the special needs of Martha's Vineyard. However, it is impossible to accurately predict the reactions of people to decisions which have not even been made!

In looking back at the creation of the MVC, one gets the feeling that it may have been accepted by island residents as the lesser of two evils. The Commission was created in an atmosphere of crisis when dire predictions about the Vineyard's future were appearing in local and national publications. This sense of urgency was exacerbated by the efforts of Senator Kennedy. The fear of federal intervention coupled with the possible consequences of uncontrolled development may have resulted in a "blind" acceptance of the state bill. Recall that the bill was endorsed by an overwhelming majority of Vineyard residents. Many of the same individuals who voted to endorse the bill, campaigned or voted for the commission's demise in either of the two nonmember towns.

There is no doubt, however, that a more comprehensive approach to growth management and land use regulation was 
needed for Martha's Vineyard. The towns, especially Gay Head, Chilmark, and West Tisbury, lacked the resources and expertise to provide the types of services and regulations afforded by the MVC. Aside from regulating DCPC's and DRI's, the staff of the Commission provides many essential services to the towns. Among these are improving transportation services, establishing bike paths, developing an oil spill cleanup plan, technical assistance to towns concerning water quality, establishing a regional hazardous waste disposal faciltiy, and lending technical support to various community interest organizations and groups.

Since the creation of the MVC, all six towns have significantly improved their ability to handle development pressures locally. Usually with the full support and cooperation of the MVC, the towns have improved the quality and scope of their zoning ordinances, subdivision regulations, and by-laws.

In addition to the Commision there are other organizations working to manage growth on Martha's Vineyard. The Vineyard Open Land Foundation (created in 1970), and Katama Farm Association can purchase sizable chunks of land or their development rights to remove them from residential development. These organizations also offer consulting services in land use planning and design to individual property owners, town agencies, and other private conservation groups involved in land use decisions on the Vineyard. Realistically, the island is much better prepared for growth pressures than it was at the beginning of the last decade. This increased 
ability to mitigate the growth pressures may be reflected in the changes in the DRI process which gives the towns more discretion as to the developments which will be reviewed by the Commission. However, it would be inaccurate to say that the improved local capabilities are equivalent to the reductions in Commission authority and jurisdiction. Solving the home rule issues remains as the key to the survival of the MVC.

The MVC provides regulations which cannot be matched at the local level, nor can the level of services. Local zoning ordinances imply cannot deal with critical areas island wide nor developments which will effect the entire region. Only now, after so much confrontation and expensive court battles, are the towns beginning to perceive the Commission as a regional agency which could include home rule. Since the island is a clearly defined region, as are many of the concerns and goals of it's residents, then the development of a regional home rule agency seems within reach. Unfortunately, the development of this perception often depends on who is in power locally. Strong antiCommission sentiments are still very much in evidence. Much work needs to be done to improve the image of the Commission in the minds of many residents.

Aside from public relations efforts on behalf of the Commission, the most important ingredient to making it work is for the towns to accept the responsibility for making it work. Without symbiosis between the towns and the MVC, the 
regional home rule formula can never be realized. It seems now that the towns are making an effot as the negotiating process, while not without setbacks, has been one of active participation by the All Island Selectman's Association and other appointed representatives.

Various formulas have been proposed to achieving a workable solution. Apparently, Gay Head, Tisbury, and West Tisbury seek a strong regulatory umbrella to protect their large tracts of open land. Tisbury, Edgartown, and Oak Bluffs seek more discretion in the regulatory process. It has been proposed to free these three towns from the Commission's regulatory jurisdiction with the other three remaining. Whatever the proposal, many other issues are tied to it such as representation, assessment, and levels of participation.

The Commonwealth of Massachusetts attempted a very difficult task when developing this regional formula. Doubtless, many of the early supporters and initiators of the Commission would balk at implementing this approach elsewhere within the state. At the very least, the form would be something quite different from that orginally introduced on Martha's Vineyard. There is no "blueprint" for creating a regional planning agency with regulatory authority.

Many valuable lessons may be gleaned from the experiences of the Martha's Vineyard Commission. Perhaps the Commission has been as successful as it has because the boundaries of the region are so well defined. In this sense, it was perhaps not the best place to launch a pilot project for regional land use legislation. If applied to the mainland, regional boundaries 
become much more difficult to define. This raises the spectre of a myriad of local issues and concerns which are much more complicated than those of the six towns of Martha's Vineyard. One might easily predict that the evolution of regional cooperation would be equal to, if not exceeding, the costs of experienced by the Martha's Vineyard Commission. This is not to say that regional planning should not be attempted. It is this author's opinion that it should and will be as real innovation is possible at this level.

The Island of Martha's Vineyard needs a regulatory agency such as the Commission. It is hoped that the efforts currently underway to achieve reforms which will make it acceptable to all six towns will be successful. 
FOOTNOTES

1. These islands can be divided into three groups: the Nantucket group, comprising 30,791 acres with the island of Nantucket accounting for all but 400 acres; the Martha's Vineyard group, comprising 67,200 acres with Martha's Vineyard accounting for all but 4,200 acres; and the Elizabeth Islands group, comprising 8,270 acres with Naushon accounting for 4,700 acres.

2. Based on discussions with Martha's Vineyard Commission staff and general observations of Vineyard affairs.

3. 1980 U.S. Census of Population and Housing.

4. Contained in memorandum from Martha's Vineyard Commission to Jon Ahlbun, January 29, 1980.

5. Population Summary excerpted by Martha's Vineyard Commission from 208 M.V. Water Quality Plan, October 11, 1979.

6. Susan B. Bastress, "The Martha's Vineyard Commission: A Regional Approach to Controlling Growth Within Island Limits" Unpublished, p.3, see also S.1929, 93d Cong., 1st Sess. (1973).

7. Estimates provided by Martha's Vineyard Commission staff.

8. Dukes County Planning and Economic Development Commission, An Economic Base Study for Dukes County, Massachusetts, (Fall, 1973).

9. Bastress, p 4 .

10. The substance of this section is excerpted from Bonny Barrs, Sue Nelson, Edwin Taipale, "Martha's Vineyard: The Prospects for Regional Cooperation", Lawrence Susskind (Ed.) The Land Use Controversy in Massachusetts, (Cambridge, MIT Press, 1975), and K. Dun Gifford,"An Islands Trust: Leading Edqes in Land Use Laws", Harvard Journal on Legislation, (Volume II, No. 3, April, 1974), pp. 417-61.

11. Metcalf and Eddy, Inc., Comprehensive Plan for Dukes County, Massachusetts, Metcalf and Eddy, Inc.

12. The New York Times, October 11, 1971, page 31, column 1.

13. S.2605, 92d Cong., 1st Sess. (1971).

14. S.3485, 92d Cong., 2nd Sess. (1972).

15. S.A. 1372, 92d Cong., 2nd Sess. (1972).

16. S.1929, 93d Cong., 1st Sess. (1973). 
17. Estimates provided by Martha's Vineyard Commission staff.

18. The American Law Institute, A Model Land Development Code, The Executive office of The American Law Institute, (Philadelphia, 1975) కో7.

19. 1977 Mass. Acts ch. 831 \$్ 12.

20. This account is based on articles appearing in The Vineyard Gazette, January 1976-December 1980 except where otherwise noted.

21. Island Properties, Inc., trustee, v. Martha's Vineyard Commission, Suffolk county Supreme Judicial Court, Civil Action No. 76-172, March 23, 1977.

22. See The Martha's Vineyard Commission: Decisions and Regulations to Implement Guidelines for (Seven) Districts as Districts of Critical Planning Concern, 1976-1977. Also see Appendix for regulations.

23. Ibid.

24. 1974 Mass. Acts ch. 637 S 11 . Also 1977 Mass. Acts ch. 831 (as amended) ş 10 .

25. Ibid.

26. Chapter 637 \$ 11 . Chapter 831 \$ 10.

27. Chapter 637 S 12 . Chapter 831 \$ 11 .

28. Most of this account is from Island Properties, Inc., trustee v. Martha"s Vineyard Commission.

29. See note 22 .

30. Ibid. "The Sengekontacket Pond District."

31. G.L. C $40 \mathrm{~A}$, S $7 \mathrm{~A}$.

32. Island Properties Inc. $v$ Martha's Vineyard Commission.

33. House Bill 3988 .

34. House Bills No. 1111 and 5604 .

35. McCarthy v. Planning Board of Edgartown, Mass. Adv. Sh. 1623 (July 2, 1980).

36. This section is based on accounts of these events from The Vineyard Gazette, May 1978 - November 1980, except where otherwise noted. 
37. According to discussion with MVC staff.

38. See letter from SSA General Manager John J. McCue to MVC, dated August 9, 1978 .

39. See Appendix: Existing DRI Checklist.

40. This opinion expressed in a memorandum from Donald I. Connors, attorney for Tyler and Reynolds and Craig, to MVC, dated May 5, 1978 .

41. St. 1960 c. 701 S $2-1,2-3$.

42. Connors, see note 40 .

43. Town of Barnstable v. Woods Hole, Martha's Vineyard, and Nantucket S.S. Authority (1962) 180 N.E. 440,343 Mass. 674 .

44. St. 1960 c 701 \$ $2-6$.

45. Ibid $\mathbf{S} 2-19$.

46. Chapter 637 \$ 2 , Chapter 831 \$ 2 .

47. Connors, see note 40 .

48. From memorandum from Alan M. Voorhees and Associates, Inc., Boston, Massachusetts to Town of Tisbury. June 19, 1978.

49. Massachusetts G.I. C. 131 S 40 .

50. See form received by MVC, February 20, 1979.

51. Conservation Commissions are a legally constituted component of local government. They are permanent, standing organizations, created by local ordinances, and sanctioned by state enabling legislation. Massachusetts G.I. C. 60 S 8c. See also Dennis C. Muniak, "The Institutionalization of Local Environmental Planning in the Northeast United States: The Municipal Environmental Conservation Commission Movement." Planning and Administration. (Volume 7, Number 2. Fall 1980).

52. Chapter 637 S 14 , Chapter 831 S 13.

53. Harvard University, Department of City and Regional Planning. An Analysis of the Impact on Martha's Vineyard of the Woods Hole, Martha's Vineyard, and Nantucket Steamship Authority's Proposed Expansion of Facilities. Harvard University, (April, 1979). 
54. Martha's Vineyard Commission, Development of Regional Impact Decision Re: Coastal Construction. June 7, 1979. Full text may be found in Appendix.

55. Chapter 637 \$ 16 , Chapter 831 \$ 15.

56. The Vineyard Gazette, June 19, 1979. p. 8, column 4 .

57. Ibid. February 20, 1980 p. 9.

58. See Appendix: History of Annual Ballot Questions.

59. H.6588 authorizing Tisbury to withdraw from the MVC by July 1,1980 .

60. Woods Hole, Martha's Vineyard, and Nantucket Steamship Authority v. Martha's Vineyard Commission, Supreme Judicial Court for the Commonwealth at Boston, Case No. SJC - 2036. June 4, 1980.

61. G.E. Carter Trustee v. Anderson, Dukes Co. Sup. Ct. Civ. Action No. 1969.

62. As of this legislative session, and "empty jacket" bill was filed in the state legislature. Indications are that the process will not be complete until 1982 .

63. According to discussions with MVC staff, these towns favor as much regulation as the Commission can provide.

64. Chapters 637 and 831 \$ 2 .

65. Ibid. \$ 4 .

66. Ibid. \$ 5 .

67. Ibid.

68. Chapter $637 \mathrm{~S} 9$, Chapter 831 S 8 .

69. Chapter 637 \$ 11 , Chapter 831 \$ 10.

70. Ibid.

71. Ibid.

72. See note 62 .

73. Chapter 831 s 12 . 
74. Chapter 637 \$ 14 , Chapter 831 \$ 13.

75. The mediation process was developed with considerable input from Lawrence Susskind, Chairman of the Department of Urban and Regional Planning, Massachusetts Institute of Technology. 


\section{Cvinglen 637 \\ THE CONMONWEALTH OF MASSACHUSETTS}

In the Year One Thousand Nine. Fundred and Seventy- rune

AN $\mathrm{ACT}$ Trotectimg land and hatek un martiu's vinfyard.

Wiereas. The deferred operation of this act would tend to defcal tes purpoit which 10 , In part, to preserve the watural and cultural character of the islatat of Marthe's Vineyard, therefore le 18 hereby declared to be an energency Iaw, neceosary for the imadlace pregervation of the public conventence.

Be th cnacted by the Senate and Hnuse of Representacives in cienceral Court anewhird, and by the auchority of the sase, as follows:

SECIION 1. Whereas, It 1s hereby declared that:

(a) thr Indand of Martha's Vineyard poescesses unique natural, historlcal. eculoglcal, sclentific, culcural, and other valut:s; and that there ts a reglomal and otetewdyr Interrat in prespriving and euhalctng these values:

(b) theoe values are belng threotened oud may the irreversibly damaged hy uncoordineced or Ineppropriate unes of the land;

(c) the protection of the heolth, selfiv. and genersi wejfare of lslund residente and visteurs requtros the estublishrent of a regional rumisstun whose purpose shall be to engure that henceforth the land usages which will be permltice are thane whlch w11 not be unduly decrimentel to chose values or to the reconosi of che LAland;

(d) the preserving and enhencling of these values requires the destgnation of djetricts of critlcal planing concern and the recogatt ion of developments of reglunal imgart, and the review thereor by che regtonal comiasion;

(6) Murh a progran Can prolect the natural character and beauty of Marthat: Vlneynrd and can concribute to the intenarre of sound locad economies and pelvale propercy values;

(1) the people of Martha's Vincyard dld, on March foureeenth, ninetron hundred and heveenty-four vore to erdorse the proviniona of thin act:

Therclere. the purpose of the cowndablun created by this act shall be to procect the healeh, wafety, and grneral welfare of Island realdents and vialtor: 
by preserving and conserving for the eijoywent of present and future gencrations the uniquc natural, fistorical, ccological, scientific, and cultural values of Martia's Vincyard which contribute to public enjoyment, insplration and sctentif?, study, by protecting these vaiues from developments and uses which would impal: them, and by promoting the eninancement of sound local economles.

SECTIOH 2. There 18 hereby created the Martha's Vineyard Comission, hereinafter referred to as the comalssion, which shall be a publlc body corporat. and which shall have the responsibilities, ducles, and powers established herein over the lands and Inland waters in Dukes county, with the exception of the Elizobeth Islands and the Indian Comon Lands known generally as the Cranberry Boga, the Clay Cliffa, and Kerring Creek, all situated in the town of Gay Huad, and 211 lands arred by the commomealth or any of 1 ts constituent agencies, board: departments, combiesions, or offices.

The combseion thall consist of tuenty-one members; one selectman from cach town on Martha's Vineyard, appointed by the board of selectwen of ghat town, or it wember of the plunning board or any other municipal agency, board, department, or offlce, appointed to the comelsstion by the board of selectwen of that tom; nine persons to be elected at lerge, 1gland-wide, provided that there shall he not lor: than one person rior nore than two persons elected from each town on Martha's Vineyard and provlded that sald elections shall be held in accordance with the provlsions of the following paragraph; one county comblssioner of Dukes county, appointed by the county comissioners of Dukes county; one member of the cabinct appointed by the governor; and four persons whuse principal residence 15 not on Martha's Vineyard, to be appointed by the governor, sald persons to have volce but not vote in deciding maters before the ccission. In the event that legislation relevant to the purposes of this act is enacted by the Congress of the Untted states, the commassion shall conslst of twenty-two members: the twent one persons described in the above section, and the Secretary of the Interior of the United States or his designee.

The election of the nine at-large meibers of the comission shall be conducted at the next state clection following the effective date of this act, and all aucceeding electlons of such members shall take place at the biennial etate election. The nowination of candidaces for election to the office of combsion member shall be in accordance with sectlons six and elghe of chapter fifty-three of the General haws, provided, however, that no more than ten elgnatures of voters shall be required on nom!nation papers for such office. 
Notwithstanding the provialone of section ten of chafter fifty-trrec of the Ceneral Law, noodnation papers for sald candidates shall be flled with the oi! : of the atate secretary on or before the centh Tuesday greceding the day of thi election. Such nomination papers shall be subfact to the provistins of acct!... seven of sald elopter fifty-three. All candidates for said of firs are herehy exempted from the reporting requirements as provided for in Gect:n sfxtgiv of chapter fifty-five of the Ceneral Laws. All appointing authorities shal! appo: : persons to the compsion no later than fifteen days after the dete of ins, election of the nise at-large combsion memers, and sald authoritfes shall

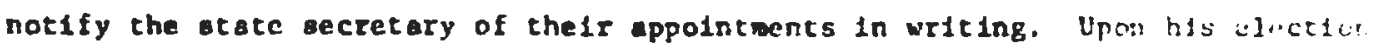
or appointment to the comission, each comission member shall be sworn to the fasthful cxecution of his duties by the town clerk in the town in which ho: res!: provided however, that the four combision wembers who do not have thetr princ $1 .$. place of residence on Martha's Vineyard shall be swom by the tow cistix of the tom on Martha's Vineyard in which they resida. Upon the qualificalion et it: members, but in no case later than December thirty-first, nineteen hundrod and aeventy-four, the comalssion members shall meet and organtze by ele ting trui: among $15 s$ members a chalrman, vice-chairman, and clerk-treasurer. Juireeding election of officers shall be heid annually, at a meeting called for flat purp. provlded that the comassion clerk-treasurer shail not concurtently wid the position of treasurer of Dukes County.

Terms of office for the clected members of the romisstun and for the nonreeldent taxpayer members shall be two yeurs. Terms of office for mobers wisc aelectmen or their designees or county commissioners shall be tor cre year anil may be renewed only upon vote of the appolnting body. The cabinet olticer appointed by the governor shall serve at the discretion of the governor. Terts. of offlce shall be computed from January first of each year.

Any vacancy in an appointed positjon shall be fllled in the racte ranner.." the original appointment for the remalnder of the unexplred tiro. Any vacane: In the elected memhership shall be fllied by a majority vote of the planninf, board, or the hourd of sejectmen in the absence of a planntog board, of il" tart.

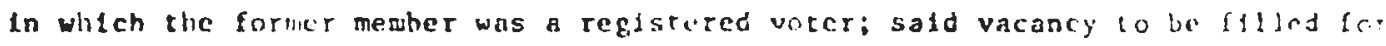
the remainder of the unexplred term. The Sccretary of the Intertor or lif: dealgnte shail serve pursuant to applicable fropral law.

The comalsiton may also contract for such additional clerical, exprer, les.i' and other assistance as may be required to discharpe les responalbilltios and ma: 
reimburse 1ta member and ataf for resonable ex, aseg incurred in the performan of their duties, Including axen is, travel and lodging.

SEction 3. The comilesion may adopt regulations for the controi of district. of critical plenning concern purouant to sections nine through twelve, fnclusive. Of this act and to apeclfy condftions and modiflcations neceseary for the conerol of developeents of reglonal impact pursuant to sections thitteen through seventecr. Inclusive, of this act.

In adopting such regulations, the comsission may include any type of regulation which may be adopted by any elty or town under the following general lave, as exended: chapter forty, section elght $C$, the Conservation Comalssiou AC chapser forty A, the zoning Enabding Act; chapter forty C, the H1stortc Distriatiti Act: chapter forty-one, ections elghty-one E through elghty-one $h$, as they relate to officlal aps; chapter forty-one, sectlons eighty-one $x$ through efghtyone CC, the cubdivision control 2aw; chapter one hundred eleven, section twentygeven B, a It relates to reglonal health boards; and chapter one humdred thirtyone, sections forty and forty $A$, as they pertatn to the proteccion of wet lands. Regulations adopted pursuan: tn section eleven or conditions and madificat inn apectifed pursuant to section seventecn by the romission under the aboveentioned general Jaws nay differ from the othetwise relevant local development ordinances and by-laws in the1x scope and nagnituje when such oxdinances und by1awa are clearly restrictive of the purposes of thr comission. In adopt sng regulations or speclfythg confltions which would not otherwse be pernileed or requited by exlating local development ordinances and by-laws the commlssion sildal? degcribe In writing and present evidence which demonstrotes that the puhlic licalth aafety. and welfare would be endongerid or that 1rreversthle damage would resule to nacural, historical, ecological, sclentifle, or cultural velues on Martha's Vineyard by the coutinulng applicalion of the existing local developaent ordinance ox by-1aw an is applies to the spec1fic district of critical planning concern or development of regional lmpact which the commisston is considering.

The comissien may be designated by any state or federal agency to participait In or recelve funds and technical assistance from any scate or faderal programs. eapecially as those programs relate to environmental. protection, conservation, Land use planning, water and al qualty control, economic development, tran:: portetion or the ievelopment of 2 ijlonwtde public services. The comisston may" authordze debt in anticlpation nf rocelpt of revenue as provided in section four.

SECTIOS 4. The commlsiston shall annually in the month of January cutimate the amount of money required to gay its cotal expentie for the followng flscal year, 
deduct estimated contributions from other sourccs, and pro rate the net expenses to each town on the basls of ILs latest tequalized vajuation for property cax purposes as estahlished pursuant to section nine of chapter lifey-eighil of the General Laws. The countssion shall certify the amount so deternined to the treasurer of each tow within the commission's furisdiction who shal I fnclude : l. sus in the cax levy of the yéar.

Upon order of the comalssion, each town treasurer shall, subfect to the provisions of section: $f 1 f t y-t w o$ and $f 1 f t y-s i x$ of chapter forty-ont of the cence:? Laws, pay to the comission treasurer the town's share of the comeission's net expenses.

The comension may recelve for the purposes of this act any funds or monfl: from any source, Including grants, bequegte, gifts, or contributions made by any Individuals, association, corporations, or by aunfcipnl, county, stnie, or federit governments. Monles so recelved shall be dishursed by the comsssion treasurit upon an order voted by the commisston; and the charges upon all tgwns may be. reduced correspondingly upon a majortty vote oi the memers if such montes wire not included in the calculation of the cown's net shares of expenses for the fiscal year.

The commission may authorize debt by a majurity vote of the comaission in anticipation of revenue to an amount not in excess of that tc be recutved durinf the current flocal year from all federal, stale, county, and loval sources. Nots: 1saued under authority of this section shal I be signed by the clerk trcasurer of the combiston, and chalrman of the combssion shall countersign and approve thro In the presence of the vice-chairman of the cominsion who shall certify to the fact on the face thereof. Such notes shall be payable, and shall he paid not leter than one year from their dates, and shall not be renewed or pald by the iss: of nrw notes, except as provided in section seventeen of chapter forty-four of thit Ceneral Lawe.

Where the Impostition of a regulation promulgated by the conantssion pursuant to section cleven Impasea costs on a nuntcipal agency, the courolsaion may traniti, roontes from tis accounts to the accunts of such agency in relmbursemetip of such costy. For the purpose: of this sibbection, the cerm "costg"' means those additional expcuses Incurred by il mullclpal agency solely in the performance of duties necessary to the erforcenent of refulations promulgated pursuant to this: act.

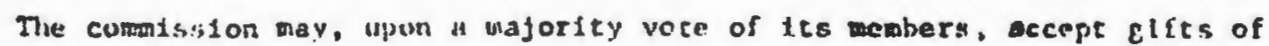
land, interests in lond, or s.rints, bequegts, gifts, or contributions for the 
$U 6.5735$

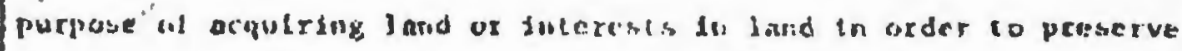

and cunsurve land or Marthe's: Viucyard fut the enjotmen: and inspiration

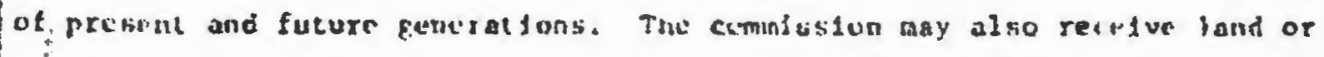

Intcrests in Jand in trust or act in asy appkopriate copactry in a erust, providu.s

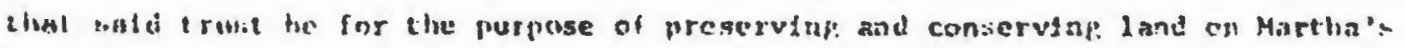

Vincyord for public use and enjoumm: .

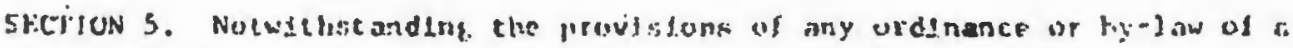
munletpality on Maselia's Vineyard, every muntclpal Jand regulatury agency shall be govituted by the prurcdures, standats, and cxiteria established pursuint io

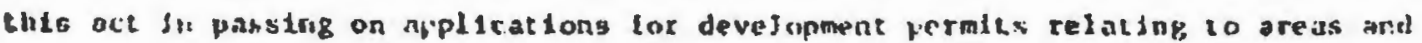
developments subject to this act. A copy of cach such perwete ermicd by ary such! ageney after the temporary murutorfom as provided fin section sever sliall la filed; with this cromulsoton.

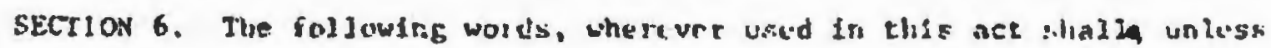
the context requlxes otherwlse, have the following: mastings:

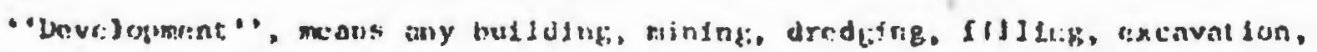
or dxtlling operatson; or any natertal change in the use of appeasanue of ally atructure os th the land itgel?; or the dividus of Jond into paretis: or a chalinat 16. the Intensily of use of iand, such tse art increase in the number of dies ling

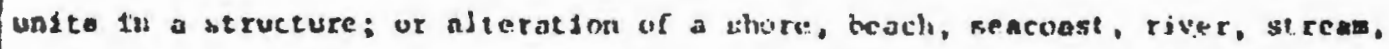

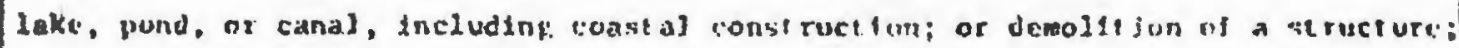

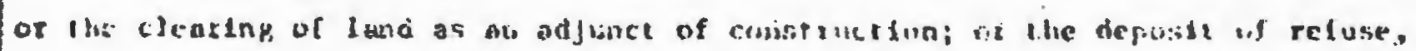
oolid, or ltquld waste or 1311 ow a parcel of labr.

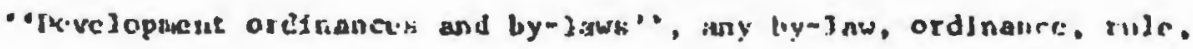
regulation, or code adojted by muntchpality for plie control or refulatiun of

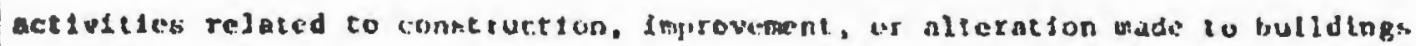

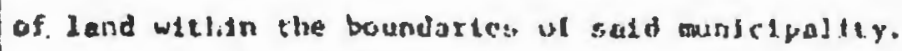

"Levelopment peralt." ony permit, Jeenke, authorsty, or minisslon re-

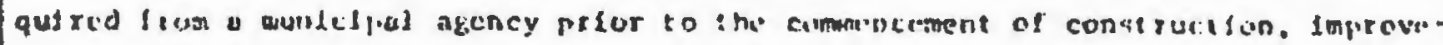
ment, or ullerilfou made le bullitngs or 3 and.

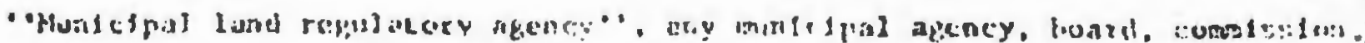

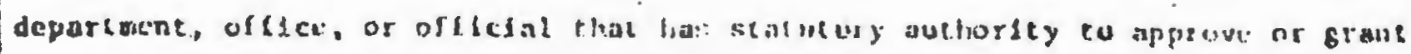

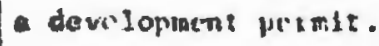

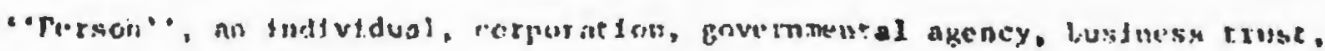

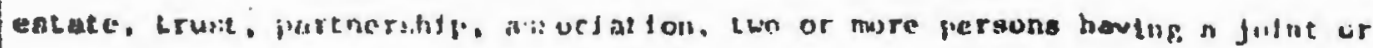
comatr Intesest, ns ary begiil antey. 


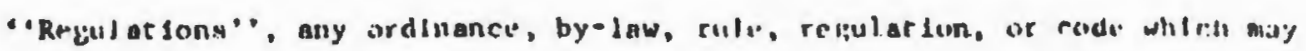

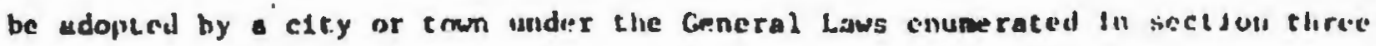

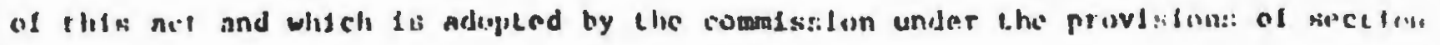
alevou.

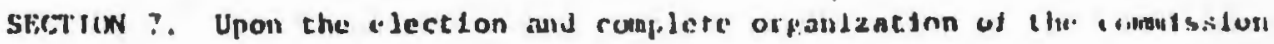

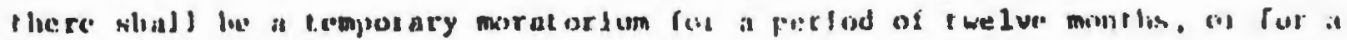

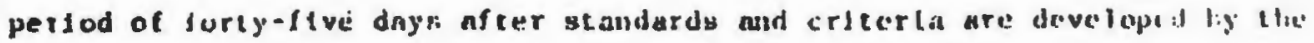

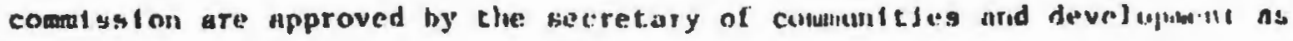
provided in kection eight, whichever perlod ts the shorter. Murin!: suld worarorluw. pieflod cinm iut horicie: sliall frant developinent perales uthly for:

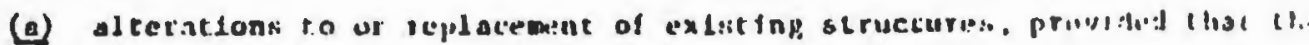

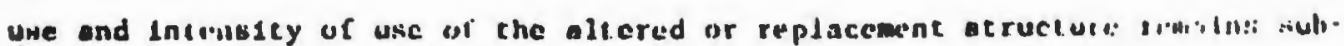

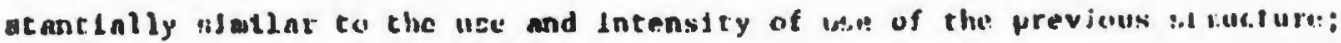

(b) developments, const ruction, or Improvements essentibl in proltere the public healll, sinfoty, or wa li:arc.

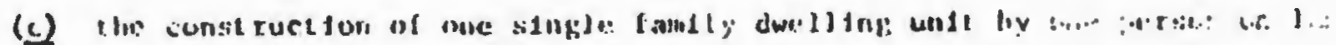

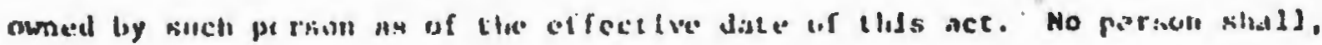

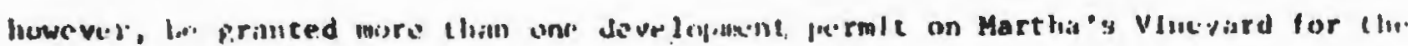
construct lon of a ringle tambly dwelling. unle during the porlod of Ille moracorlan,

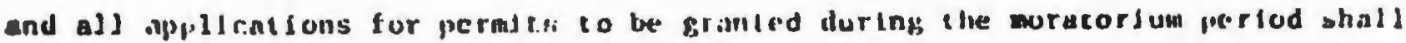

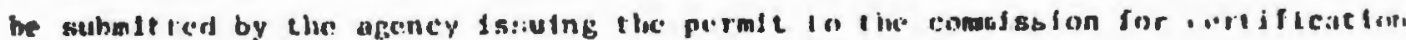

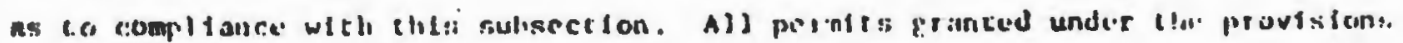

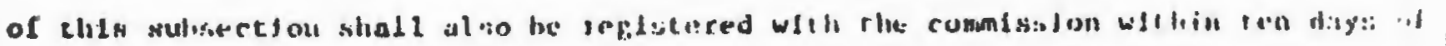

the grant tug of sald perust:

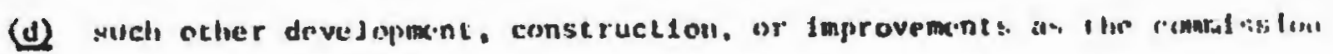

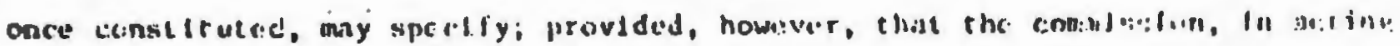

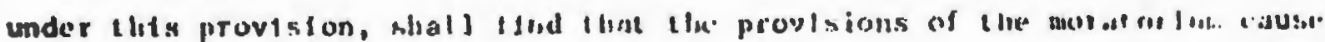

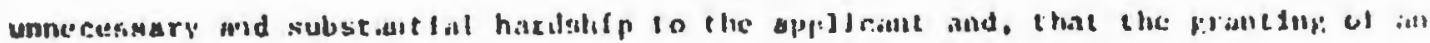

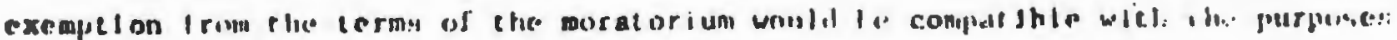
of I.his act:

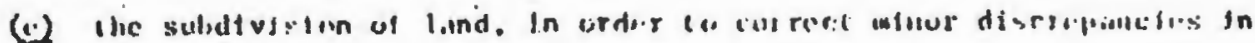

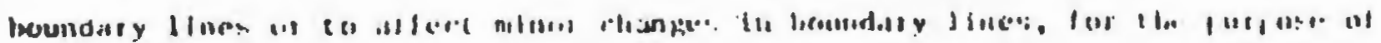

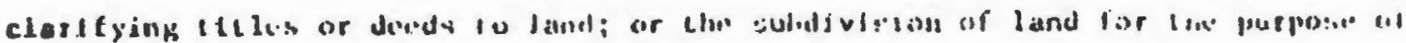

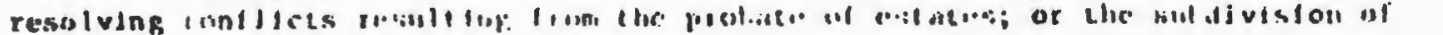

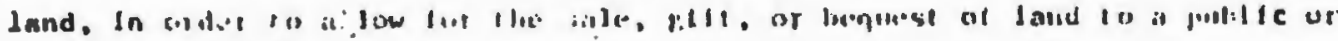

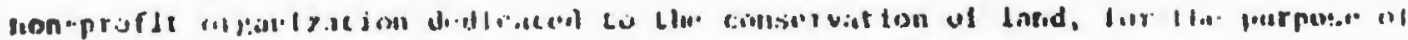


conserving or preserving open spoce on marcha's Vineyged, or the subdirision of land by a pertion Into not wore than three lots during the moratorfum persod. Ohily one ouch subulvigion shall be npproved for each person, notwlthst anding that such pergon ownk land in more than one town on Martha 's vincyard, and provided furtlicer. that there shall be no further subdivision by any person of the parces 3 ;0 subdivided during the moratorlum pertod;

(f) the construction of seperate, anclilary, donresidential structuress rirh as goragcs, barns, greenhouses, other agricultural structures, studics, dorks, $\because$ wharves or the construction of structures such as decks, patsos, porrlies, brabres, or otudios as additions to exfsting structures; provided that the ust wf iny etructure constructed under this subsection with the exception of agricultural otructures shall not be used in any manier for commerchal activitles.

Nothing in thle act shall be constried to problbit the planing board of a tow on liarthe's Vineyard from approving any definftIve subdivision plan pur suant to chapter forty-one of the General Laws, provided that such definitive subdicision plan mas duly submitted to said plenning board prior to the effective dete of this act. Nothin: In this act shall be construed to prohibit ald planning boards from accepting for congideration for approval after the effective date of this act any preliminary or definitive aubdivisicn plensepurguant to chapter forty-one of the General Larr, provided, bowever, that no approval on any such definitive plen shall be granted by a planning board before the end of the temporary moratorium, except for those subdivieians permitted by subpuragraph (e) of the first paragraph of this section.

SECTION 6. Prtor to any congisston action jursuant to sections nince or four. teen, and whthin one year following the affective date of this act, the cumission ahall subrote to the secretary of communities and development (a) standards and criterin wilch the commission proposes to use in dotermining wliether tir live a prnposed arca la one of critscal. planning concem as that tern is defined in section nine of thds act; and (b) standards and crdceria which the combisston proposes in uge and to be used by munfetpal authoritles in determining whether or not a propo.. development is one of regional impact as that trem is deflned in section thirteri

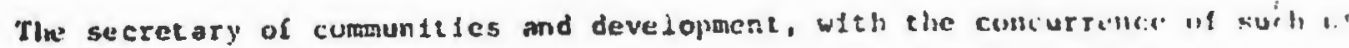
members of the governor's cabinet as the guvernor shall designate fur thi: purbon... may approve, disapprove or amend and approve with, the advice and con:allt al the

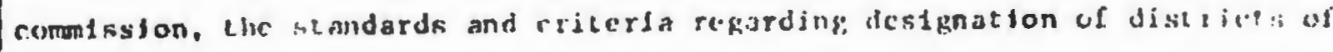

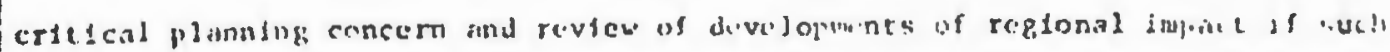

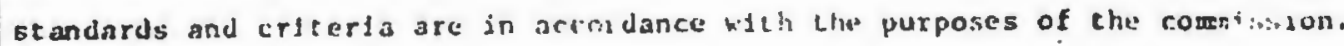
The secretary of commutt iss and divelopment and such other cabluct miniers defighated by the governol shill approve, dfeapprove. or amend and alprove:

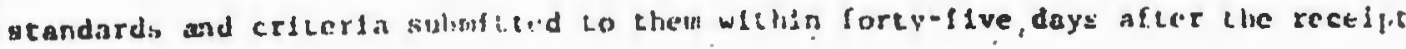
of such standard: ind irituilis. 
.

SECTION 9. The commission may, after notice to all munici-

17 palities which include within their boundaries any part of the area

18 of a proposed district of critical planning concern and after notice

19 and public hearing pursuant to section two of chapter thiry $A$ of

20 the General Laws, designate specific geographical areas on Martha's

21 Vineyard as districts of critical planning concern. The designatiun

22 of such districts shall be made only in accordance with the 8 tandaris

23 and criteria for districts of critical planning concern approved

24 pursuant to section eight.

25 A district of critical planning concern may be disignated only

26 for (a) an area which possesses unique natural, historical, ecological.

27 scientific, or cultural resources of regional or statewide signifi-

28 cance; (b) an area which possesses marginal soll or topographic

29 conditions which render it unsuitable for intense development; or

30 (c) an area significantly affected by, or having significant impact

31 on, an existing or proposed major public facility or other area of

32 major public investment. A major public facility is any publicly

33 owned facility of regional importance except:

(1) any public facility operated by a municipality primarily

for the benefit of the residents of that municipality, or by any agency serving primarily the residents of one municipality;

(2) any street or highway which is not recognized as or maintained as a part of the state or federal highway system; or

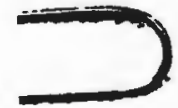
residents of one municipaity. districts of critical planning concern may be made by the commisston or by a board of selectmen, planning board, board of health, or conservation commission of any of the towns affected by this act

7 for any area within or without its municipal boundaries. Nominations

8 also may be made upon petition of twenty-five taxpayers of any town

9 on the island. Within forty-five days of the receipt of a nomination

10 the commission shall accept or reject the nomination for consideration.

11 Nominations which are not accepted for consideration shall be returned

12 to their sponsors with a written explanation of the commission's

13 reasons for not accepting the nomination within forty-five days of

14 submission. The commission may consolidate nominations which 


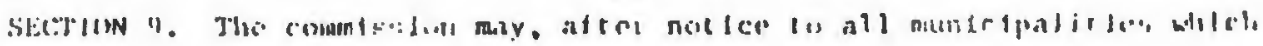

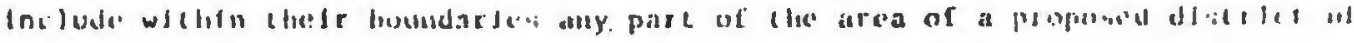

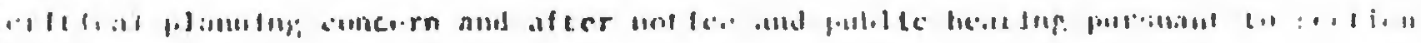

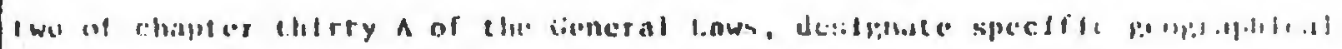

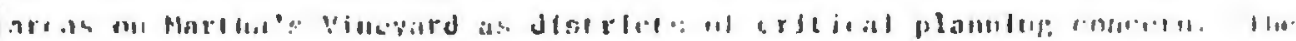

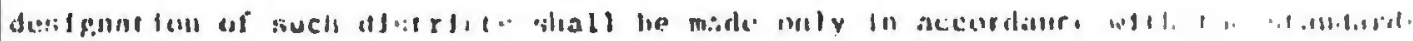

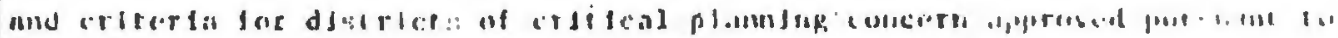
ircelom es diht.

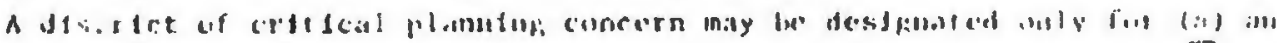

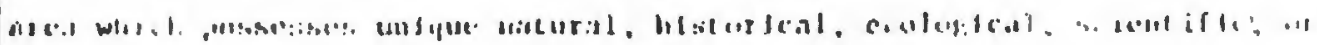

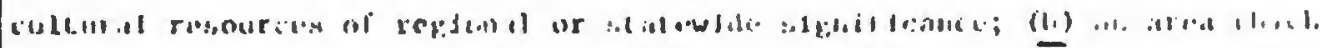

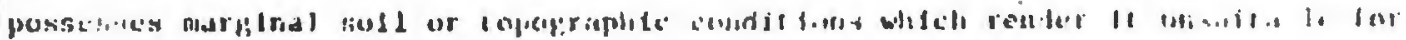

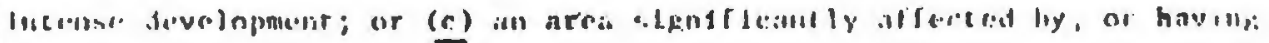

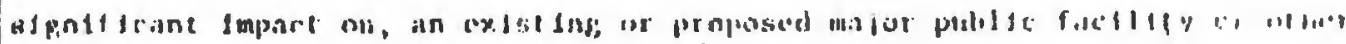

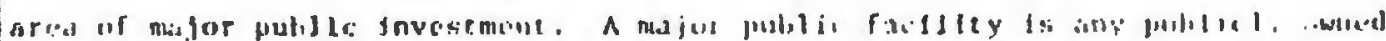

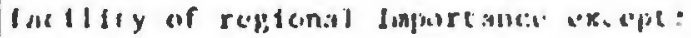

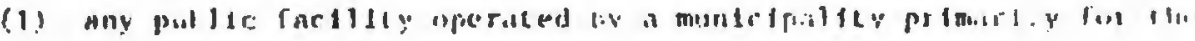

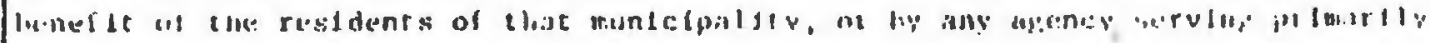

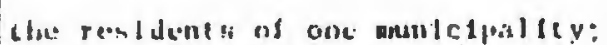

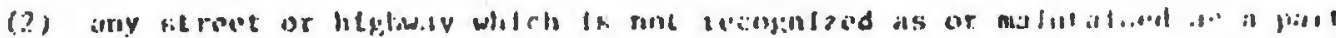

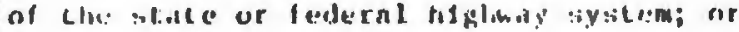

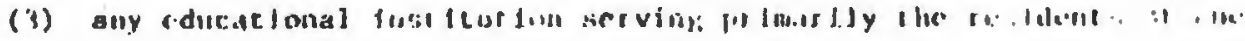
minlelinitsy.

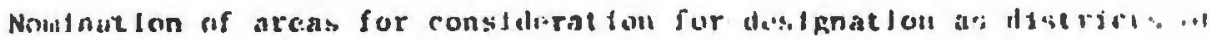

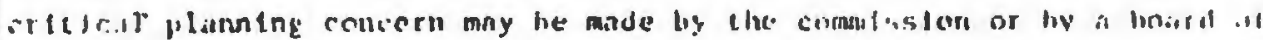

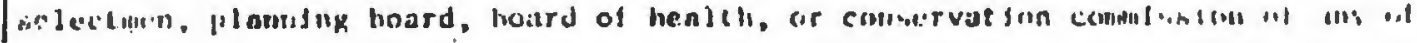

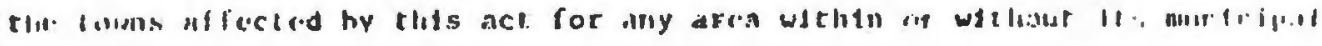

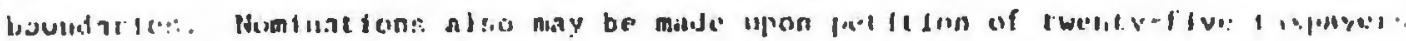

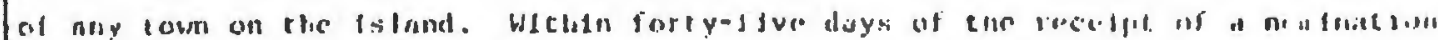

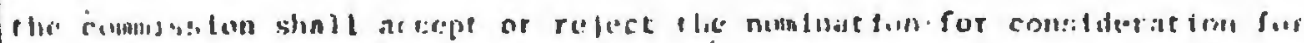

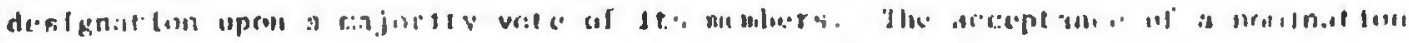

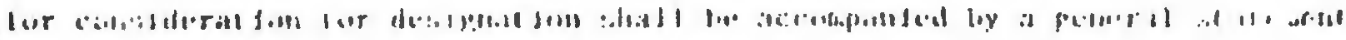

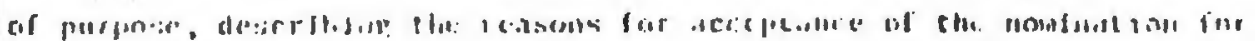

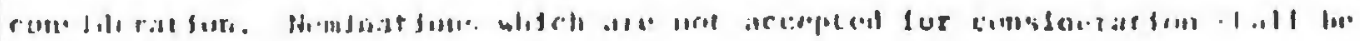

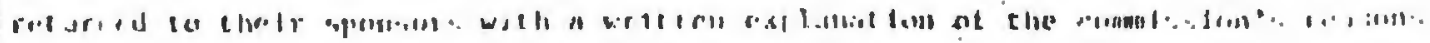

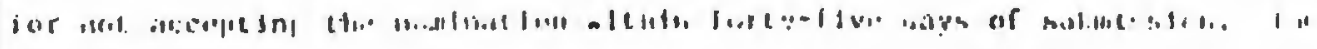

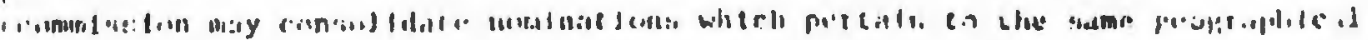




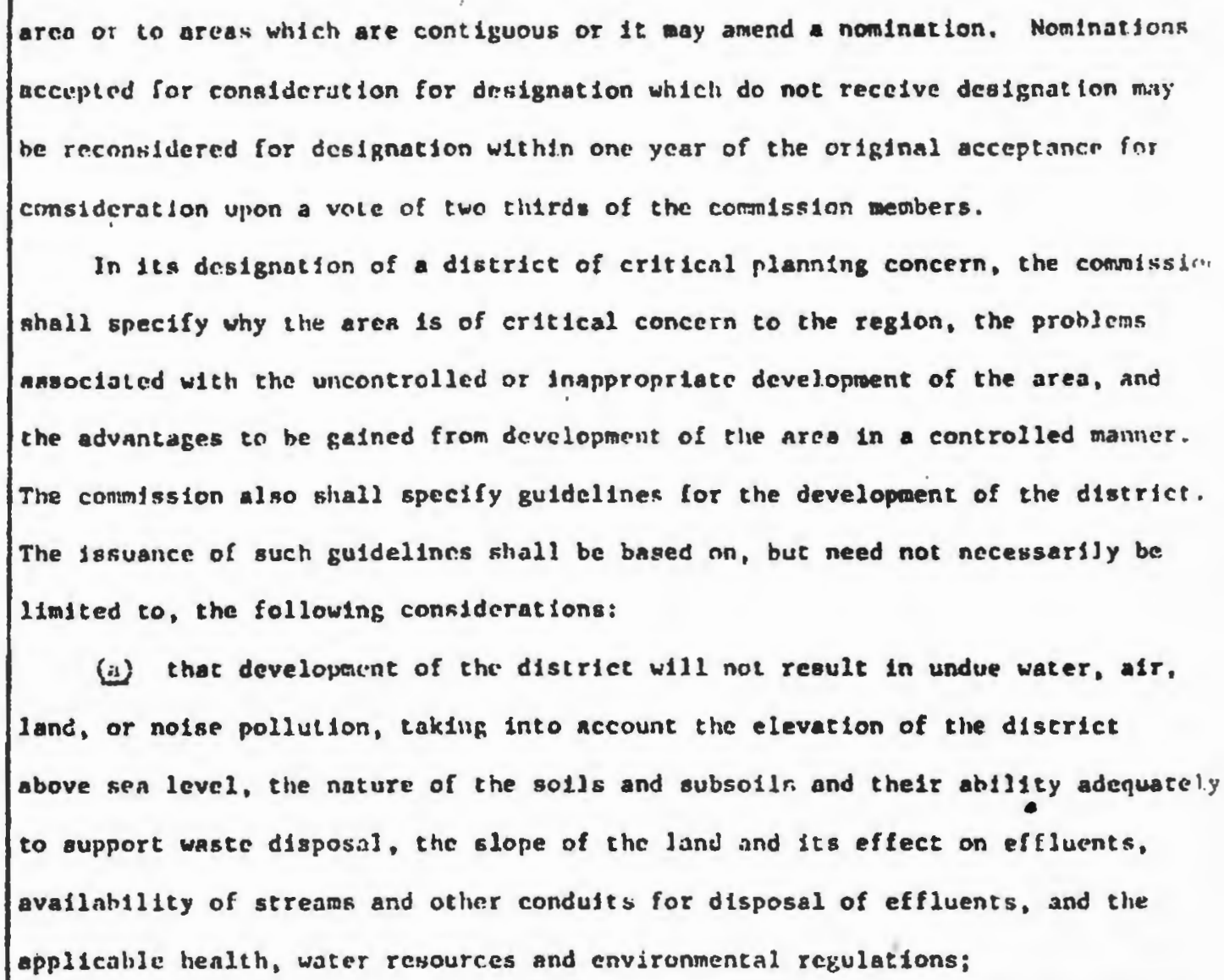

(a) that developentent of the district will not result in undue water, alr, land, or nolse pollution, takluf into nccount the elevation of the district

(b) that the existing water supply of the dfitrict will not be unreasonably burdened by any development;

(c) that development of the district will not result in inereased heach erosion or damage to the littoral ccology or wetlands;

(d) that development of the district will not result in increased beach erosion or damage to the littoral cology or wetlands.

In any npplication for a development permit wifch applies to an area within a distrlct of critical pjanning concern, the burden of proof of compliance with the above considerations shall be on the applicant. The comission may amend or refeind the designation of alstrict in the manser provided for desifnation.

Nominations accepted for consideration for designation which do not recelve designation from the commission withlo sixty days of the date of acceptance sliall be returned to their sponsors with a written explanation of the commisston's reasons for not grantiug the designarion. Inttial nominations for distrfets of crillcal planning concern shall not be submitted to the conmission for twelve wonths following the effective date of this leginlation, or uncil standards and critcria are approved as frovtred in section etght, whichever period ls the jesser.

SECIION 10. No munictpality shall grant a developrent peralt applfcablo 
whlifn a digtict of celtical planning concern except in accordance with regulutions pronulgated pursuant ro kection eleven.

The nereptincr of a nouluution for comblderation for designation of a

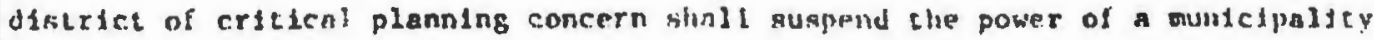
to frant druclopnent permits applicable whohin tise distelct; provided, Inwevar that unt1] regulatiofator the district odopted pursuant to section elcver have hecome effecive, a minlcipnlity may grant development peralts, applitable withit. the district if:

(a) tic type of proposed construction. Improvement, or niterat ion $1 \mathrm{~s}$ pancnttal to protect the public health, safety, and general welfare hecause of an exioting emergency certifled by the commissian, and,

(h) a development ordinance or by-law had been in effect immediately pilor to the uomination of such arca and development perolts would have been grantrot under such ordinance or by-1aw.

SECTiON 11. After desipnation of a distriet of eritical plsubinp concert. a municlpality whose boundarfes include all or part of the district uay adept regulations in accordance with the guidelinos for the development of the districi as set forth in the designation. In adopting such regulations, each munteirafity ulall have all of the powera it otherwise had under the General Laws. A copy of regulations so adopted shall be transmited to the commission. It the comaissteis intermines that the regulations adopted by a municlpality comply with the sujdelines for the development of the distriet speclfled in the commisstons" Jesignation of the district. clie commission shall, after notice to all nunicipalities witch include wthin their houndaries any part of the district uf crsteal planning concern and after notice and publte hearing pul cuant to sectiun two of chapter thitry A of tire Genersl Laws, approve or anend and approve surth regulations. When two or more munjelpalitles may, purguant to chis act, adopt regulit inns for arciss within a single districe, the commisston shatl encourafie such mulatpaldtess to adipt compatible regulations.

If a munfelpallty whose boundarles irrlude ill or part of the nlstrice ratls zo submit repulaltons which comply with the puidelines for the divelopment

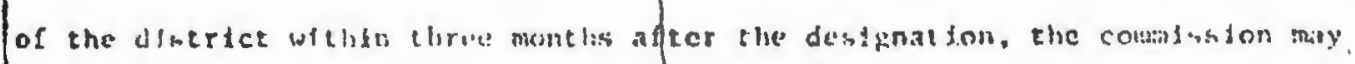

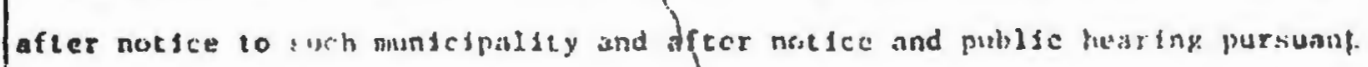
to section two of ehipter thitty $A$ of the Kieneral laws, adope refulations applicaple to such mirreletpitily sortion of the distrtec. Such refulat tons shatl

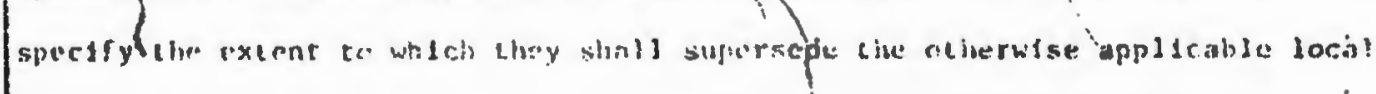




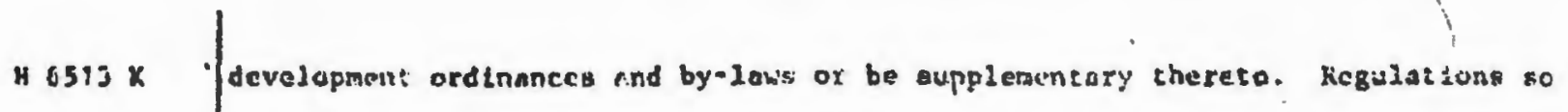
adopted shall be ondy the typeo spectfied in section three.

All regulacions so odopted shill be incarporated, without regard to the provisions of section talrty-two of chapter forty of the General Laus, by the muntcipility Into the offlclal ordinunces, by-laws, and meps of the munfelpality

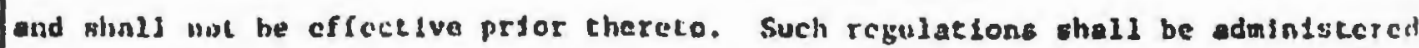
by the municipality as. If they were part of tts development ordinances and by-law: If such a regulatjor requires enforcement by en adminiatrative off Ice or body which has not been constituted by aunicipality, the board of selectmen of the muntelpality shall enforce sald regulation. At any time after the adoption by the comulysion of such regulations, the manicipality concerned ay adopt regulations which, If approved by the comission as provided in the preceding subsection, shall supersede any regulations adopted by the commistan pursuant to th1s subscction.

A municlpality may umend or reacind regulations in the manner provfded fobr adoption and approval.

seCTroN 12. If the commssiston his not approved or adopted regulations applicable to the entirety of a district within twelve months after destgriation of aveh distr1et, the degignatson of such part for which regulacions have not been npuroved or adopted sholl be teminated. No part of the area formerly : designated as a distict shall again be designated as a diseriet for a period'of twelve months from the datc of such termination. Norice of such icrmination shald he eiven in the same manner as provided for desigmation.

SECTION 13. The comnisintion shall adopt and submit for approval, pursuant ro section elght. Etandards and criteria which specify the cypes of development which, hecnuse of theis magnilude or the magnifude of thefr effect on the surrounding environment, are $2 / \mathrm{koly}$ to present development issues significaut to more than one municlpality of the foland of Martho's Vineyard. For the purpose of this act, such types of devejopment shall he termed "developments of reglonil Impaci".

In adopting standards and criterla pursuant to this secton, the commisston shall con:jfier, but shall nut be limited by, hle following considerations:

(a) the extene to which a cype of development would create or alleviate environmental prohlems, Including, but not 1 fmited to, alr, water, and nelse poliution;

(4) the siza of the stite to he developed; 


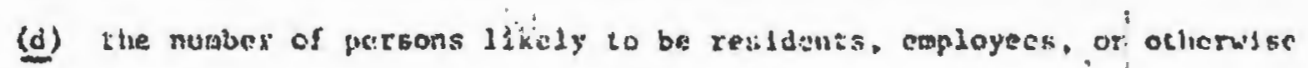
prexent;

(e) the extent to which a type of deveinpmisus dis jutended to sirvi: a reglunal market:

(1) the lucation of a type of development near a wacerway, publiely-owned land, or $n$ municipal boundary; and

(g) the extent to which the developrent weuld requize the provistun of the followlag munlelpal or reglonal gervices: solsd waste disposal, puhle watar supplies, swage treatment faciltties, parking facillties and courlsi sievicrs. and public cducation facilitics.

sfCrIon 14. The governmental agency within each muntclpolity which hisi responsfiflfty for issuing a development permtt, or when multiple permft is are required, the local planufug board, or board of selectmen in the absence of a planning board, shall In arcordance with the standards and criterio approved pursuant to section etght deternatne whether or not a proposed development, for which application for a development permli has been made, is one of togiondl impact. It shall refer the application for the developwent permit to the , comensasun.

SFCTION 15. The comission shajl review all appllcations for development permils for developuents of regional Jmpjet and shall permit the ruferring agency to grant a development permit for such a development oriy if it finds, after notice and public hearling pursuant to section two of chapter thirty $A$ of the General Laws, Chat:

(a) the probable bencfit from the proposed development w111 excecd the probable detriment as evaluated pursuant to section stxteen;

(b) the proposed development will not substantfally or unressonally Interfere with the achievenent of the objectives of the general plan of any. munfctpality or the gencral plan of Dukes county;

(c) the proposed development is consistent with municipal development ordinances and by-1aws, or, If it is inconsistent, the inconsistency is necessury to crablc a substantial augment of the population of a larger conunity of which the municipality is a part to securc adequate opportunittes for heusing, education, or recrealion, and

(d) If the proposed development is located in whole or in part within a desfinated distriet of crsticil planning concern, it is conslstent wibl the regulat jous opproved or adopted by the commissinn pursuant to sectlon cleven above.

b $-13-$ 
SECTION 16. In maktig a sinding of the prohnhis benefite and de:riments of

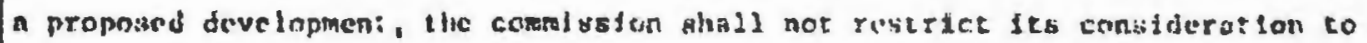

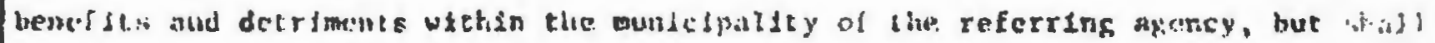
consider also lise impact of the proposed development on the arcas withla other

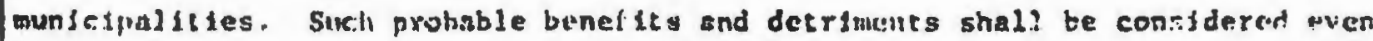
If they are indirect, Intankible or not zeadily quantiflable. In evaluet ank the probnble benefits and detriments of a proposed development of reglonal Impact, the coumlseinn shall conslder, logether with other relevant factors, whether:

(a) developmart a: the proposed loeation is or 1 s not essential or especially approprlat: In vied of the avallable alicrnatives on the isiand of Marthi's Vineyard;

(b) duvelopmert in the manmer proposed will have a more favornble or adverse Impact on the cnvironment in comparison to alternative nanners of development;

(c) the proposed develepratint will savorably or adversely affect other persons and property, and if so, whether, because of clecumstances pecullar to the location. the effect. Is likely co be greater than is ordinarily asseclated With the development of the type preposed;

(d) the proposed developherit will favorably or adversely affect the supply of needed low and woderate incoine housing for lsland residents:

(e) the proposed tevelupment will Savorably or adversely affect the provision of munla:ipal services ard the burden on c.axpayers in raking provision therefor;

(5) lie proposed developnent will use eftirlantly or burden unduly existsng. public faclitties or those which are to be developed within the succeeding five years:

(a) the propused devejopinent will ald ur interfere with the abillty of the munlcipality to achleve the objectives set forth in the munlclpal general plati; and

(h) the proposed developmeds whll furblier or contrivene land development objectives and policies developed by reglonal o: state agencses.

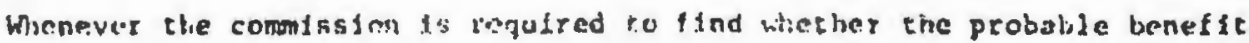
from o pruposed development of rasploswl impaci will exceed the probablo detrlincne, 1t shall prepare a witcen optnion settink forth the grounds of its findings.

Siction 17. No referrlog ajancy shan srane a development permit for a developncill of resional ingact swe with tie permistion of the commlssion. In

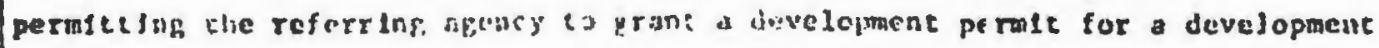




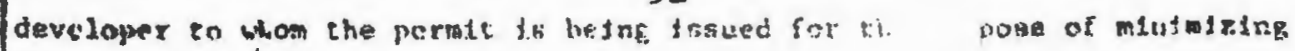
econtratc, taclal, or environmental damage.

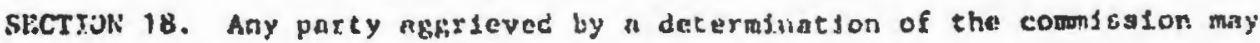
appeal to shy court of comptent jurisddction. The court shall hear all pertinent evidence and shall unnul the determination of the conorssion if $1 t$ IInds that katd decemination is unsupported by the evidence or exceds the nuthority of the commission, or 14 may remand tic case for further artion by $\mathrm{ll}$. comatsation or may wake nuch other decrec as is fust and equituble. Cosen of $t$

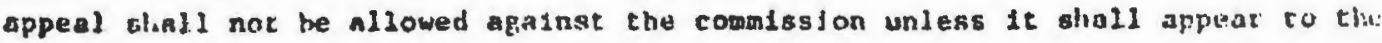
court thut the commisiton acted with gross negligence, bad fulth or mallce. Cos of nuch appcal shall not be allowed against the appellant uniess it sliall oppos? to the court that the appellawt acted lin bad falth cit wh malice.

stecjow 13. Effective upor the date re the f1:st meeting and upon the organization of the commingtion, chacter stx hundred and ninety of tlip acts of

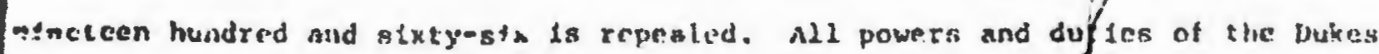
County Planning and Lconomic bevelopment Combston, Inclughrig those authorlzcd by the contucowenlth and the foderal government, shall be transferred to the compisition and the terins of offtce of the memhers of the Dukes County lianing and Promomit bevelopment Commistion shajl explre at that time. For the putposes of exceuting, the functlon: of the Wukes County ylanntng and Ecoumtc Development Commission as tranglerred, the conmtstion boundarfes shajl include abl of the

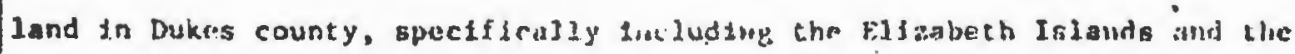
Ind an Common landi.

All employees of the Dukes County Planning ard Economic Development Commins who liold positjons with the Dukes County Planning and Econonic Development Commission Immediately prine to clice repeal of cliapter six hundred and nincty of the acts of nineteen hundred and stxey-six shall be transferred to the commssion at the tinc of repeal of sald chapter $s i x$ hundrced and ninety. Such transfer shal be without impisirment of senfortly, retirenent, or ofher rights or linefits,

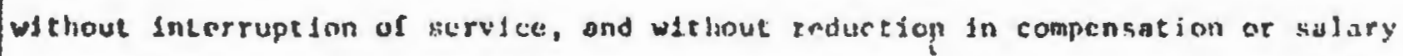
Rrade Hotwithstanding any change in juh title or dutiec resulting from such eronitur.

A) books, papurs, rccords, documonts, cqupment, ilands, hitercests in land. budddugs, factlities, and olme property, boll personal and real, which Immedintely prior to the repmil of chaples six hundres ind nincty of the acts of nincteen huntred nnd stxty-six, are in the custody of the nukes county plannteng

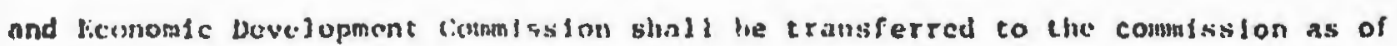




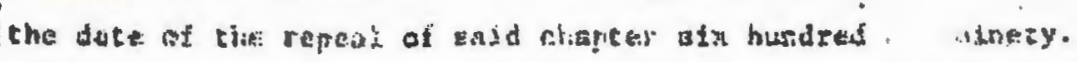

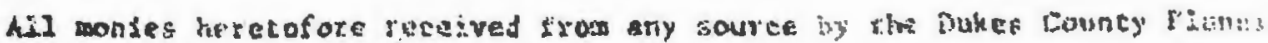

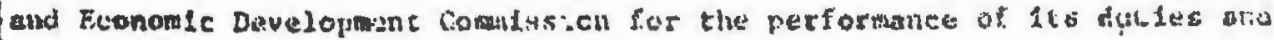

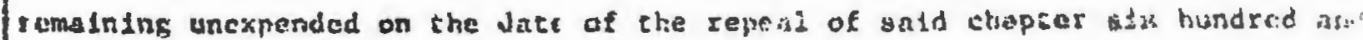

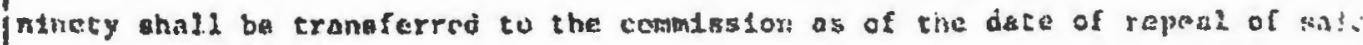
chnpter mind shall be avallaile for expendscure by the commigsion.

All duly exlsting contracts, leases, and obligations of the Dukes Co:inty Planning and Beonowic Development Cownission whlch are in force irmediately $\mathrm{pr}$ to the repial of sald chapter $81 x$ humdied and nincty shall be cransferred to :comiuston as of the dace of the repes of sald chapter. All petgtions, heari. and ather procecdsnge duly brought betoje, and all prosecutfons and legal and

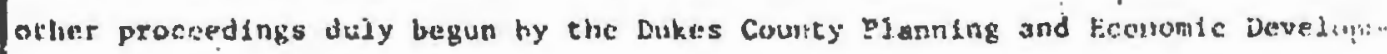
Comiustun wilch arise from or relace to the exereffe of the polexs or dutles of eatd comianion and whlch are pending immediately prior to tise rapeal of siat. chapter six hundred and ninery, ohall continue umebated and rempin in force notwithstanding the repeal of sate chapter.

In addition to performing its funetions under this act, the commission mi:perform ony function assigned to lt inder federal law.

SECTIN 20. The provisions of thit set are severable, and if any of fts provistous shall bi held unconstitutinnal or invaild by any court of competeni Jurtsdietion, the dectition of such coure shall not fifect or lingul any of the runninding provisions.

House of Representerlves, Jul: 18 , ilis

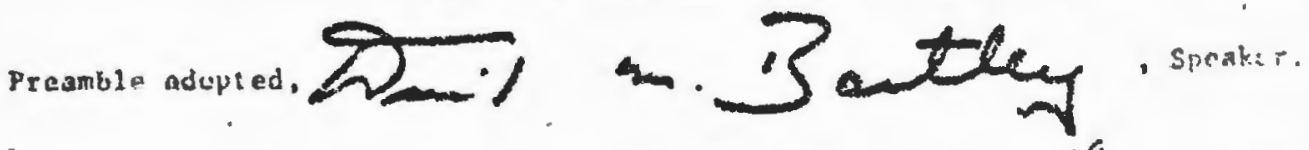
In Senote. July 19 . isis.

Prcamble adupted,

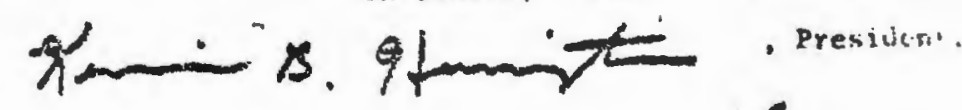
House of Representiatives, Juty $18,1976$.

HII pasied to be eiacted.

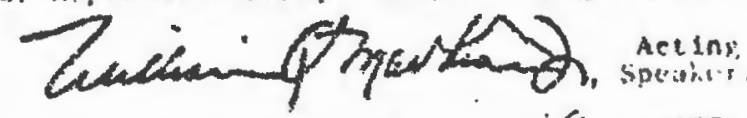
in senzte, july iq, iniu.

B111 passed to be inactid,
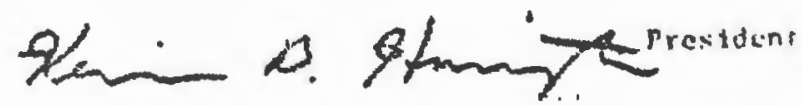

3.1. 27, 1974

$\mathbf{a t}$ heproved.

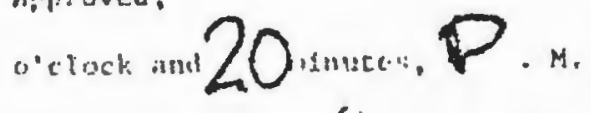

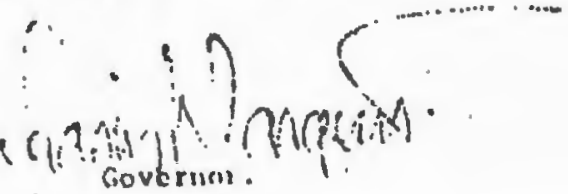


THE COMMONHEALTH OF MASSACHUSETTS

1. Chap. 831 as amended. AN ACT FURTIER REgULATING THE PROTECTION OF THE LAND AND

2. WATERS OF THE ISLAND OF MARTHA'S VINEYARD.

3. Be 1t enacted by the Senate and House of Rerresentatives in General Court

4. Assembled, and by the Authority of the Same as Follows:

5. SECTION 1. The 1sland of Martha's vineyard possesses unique natural, historical,

6. ecological, scientific, cultural, and other values and there 18 a reglonal and state-

7. Wide interest in preserving and enhancing these values.

8. These values are being threatened and may be irreversibly damaged by uncoordi-

9. nated or Inappropriate uses of the land.

10. The protection of the health, safety, and genersi welfare of 18land residents

11. and visitors requires the establishent of a regional cownission whose purpose shall

12. be to ensure that henceforth the land uases which will be permitted are those which

13. will not be unduly detrinental to those values or to the economy of the 1sland.

14. The preserving and enhancing of these values requires the desigmation of dis-

15. tricts of critical plamning concern and the recognition of developments of regional

16. Impact, and the review thereof by the regional conmission.

17. Such a program can protect the natural character and beauty of Martha's Vineyard

18. and can contribute to the maintenance of sound local economies and private property

19. values.

20. The people of Martha's Vineyard d1d, on March fourteeath, nineteen hundred and

21. seventy-four vote to endorse the provisions of chapter six hundred and thirty-seven

22. of the acts of nineteen hundred and seventy-four.

23. The purpose of the commission created by this act shall be to further protect 
1. the health, safety, and general velfare of 1sland residents and visters by pre-

- 2.. serving and conserving for the enfoyment of present and future generations the unique

3. natural, historical, ecological, scieatific, and cultural values of Martha's vineyard

4. which contribute to public enjoyment, Inspiration and sclentiflc study, by protecting

5. these values from development and uses which would impair them, and by promoting the

6. enhancesent of sound local economies.

7. SECTION 2. There 1s hereby created the Martha's Vineyard Commisston, hereinafter

8. referred to as the combalion, which shall be a public body corporate and which shall

9. have the reaponsibilities, dutieg, and povers established herein over the lands and

10. waters In the county of Dukes County with the exception of the Elizabeth Islands and

11. the Indian Common Lands known generally as the Cranberry Bogs, the Clay Cliffs, and

12. Herring Creek, all stuated in the town of Gay Head, and to the extent they are ex-

13. cluded from the responsibilities, dutles and powers of the towns, all lands owned by

14. the commonwealth or any of 1 ts constituent agencies, boards, departwents, commissions

15. or offlces.

16. The coumlssion shall consist of twenty-one menbers, except as provided further

17. In this section; one selectman or a resident registered to vote frow each tom on

18. Martha's Vineyard, appolnted by the board of selectmen of that town; nine persons to

19. be elected at-large, 1sland-wide, provided that there shall not be less than one person

20. nor more than two persons elected frow each town on Martha's Vineyard and provided

21. that sald elections shall be held in accordance with the provisions of the following

22. paragraphs; one county comissioner of the county of Dukes County, appointed by the

23. county commiseloners of sald councy; one member of the cabinent, or his designee,

24. appointed by the governor; and four persons whose principal residence 18 not on Mar-

25. tha's Vineyard, to be appointed by the governor, sald persons to have volce but not

26. vote in deciding matters before the commission. In the event that legislation rele-

27. vant to the purposes of this act 1 s enacted by the Congress of the United States, upon

28. certification of such enactment by the President of the United States and by the

29. governor of the commonrealth, and one nember of the cabinet of the United States or 
1. the designee of such cabinet mewber shall also be a member of the comission.

2. The election of the nine at-large members of the commission shall be conducted

3. at the biennial state election In nineteen hundred and seventy-elght and all suc-

4. ceeding elections of such nembers shall take place at the biennial state election.

5. The nomination of candidates for election to the office of comission member shall

6. be In accordance with sections $s i x$ and elght of chapter fifty-three of the General

7. Laws, provided, however, that no more than ten signatures of voters shall be required

8. on the nomination papers for such office. Notwithstanding the provialons of section

9. ten of chapter fifty-three of the General Laws, nomination papers for said candidates

10. shall be filed with the offlce of the state secretary on or before the tenth Tuesday

11. preceding the day of the election. Such nomination papers shall be subject to the

12. provisions of section seven of sald chapter fifty-three. All candidates for sald

13. office are hereby exempted from the reporting requirements as provided for in section

14. sixteen of chapter fifty-five of the General Laws. All appointing authorities shall

15. appolnt nembers to the comalssion no later than fifteen days after the date of the

16. certification of the election of the nine at-large comission members, and said

17. authorities shall notify the state secretary of their appointments In writing. Upon

18. his election or appointment to the comission, each comisgion member shall be sworn

19. to the falthful execution of his duties by the town clerk of the tow in which he

20. resides; provided however, that the four comission members who do not have their

21. principal place of residence on Martha's Vineyard shall be sworn by the town clerik of

22. any town on Martha's Vineyard. Upon the qualification of Its members, the comisision

23. members shall meet and organize by electing from among 1ts members a cha1rman, vice-

24. chaiman, and elerk-treasurer. Succeeding election of offlcers shall be held annually.

25. on or before December thirty-f1rat, at a meeting called for the purpose; provided that

26. the commission elerk-treasurer shall not concurrently hold the position of treasurer

27. of gald county.

28. Terms of office for the elected members of the comission and for the non-resident

29. taxpayer members shall be two years. Terms of office for members who are selectmen or 1) 1 
1. their designees or county complssioners shall he for one year and may be renewed only

2. upon vote of the appointing body. The cabinet member or his designee appointed by

3. the governor, shall serve at the discretion of the governor. Terns of office shall

4. be computed from January first each year. Any vacancy in an appointed position shall

5. be filled in the same manner as the original appointment for the remainder of the

6. unexplred term.

7. Any vacancy in the elected membership shall be filled by a majority vote of the

8. planning board, or the board of selectmen in the absence of a planning board, of the

9. coun in which the former member was a regletered voter; sald vacancy to be filled for

10. the remainder of the unexplred term. The combssion shall notify the municipaitty

11. of any vacancy in the elected membership by notice to the town clerk and planning

12. board at the town of residence of the elected member whose office is vacated. The

13. cabinet nember of the United States or his designee shall serve pursuant to applicable

14. federal law.

15. The comission may also contract for such additional clerfcal, expert, legal,

16. and other assistance as may be required to discharge 1ts responsibilities and may

17. refmburse 1ts members and staff for reasonable expenses incurred in the performance

18. of their duttes, Inciluding meals, travel and lodging.

19. SECTION 3. The comission may adopt regulations for the control of districts

20. of critical planaing concern purauant to sections efght to eleven, inclusive, and to

21. specify conditions and modifications necessary for the control of developments of

22. regional inpact pursuant to sections twelve to sixteen, inclusive.

23. In adopting such regulations, the comisstion may include any type of regulation

24. which may be adopted by any city or town under the following General Laws: section

25. eight $C$ of chapter forty; chepter forty $A$; sections cighty-one $E$ to eighty-one H,

26. Inclugive, of chapter forty $C$ as they relate to offictal maps, and sections eighty-

27. one $K$ to eighty-one $G 6$, Inclusive, of chapter forty-one; section twenty-geven $B$ of

28. chapter one hundred and eleven, as it relates to regional health bonrds; and sections

29. forty and forty $A$ of chapter one hundred and thirty-one, as they pertain to the

1 
1. protection of wetlands.

2. Regulations adopted púrsuant to section ten or conditions and modifications

3. specified pursuant to section sixteen by the commisston under the above-mentioned

4. General Laws may differ from the otherwlse relevent local development ordinances and

5. by-laws in their scope and magnitude when such ordinances and by-lawa are clearly

6. restrictive of the purposes of the commisaton. In adopting regulations or specifying

7. conditions which would not otherwise be permitted or required by existing local

8. development ordinances and by-laws the commission shall describe in writing and

9. present evidence which demonstrates that the rublic health, safety, and velfare would

10. be endangered or that Irreversible damage would result to natural, historfcal, eco-

11. $\log 1 \mathrm{ca} 1$, scientific, or cultural values on Martha's Vineyard by the continuing appli-

12. cation of the existing local development ordinance or by-law as it applles to the

13. specific district of critical planning concern or development of regional impact which

14. the commission is considering.

15. The commission may be designated by any state or federal agency to participate

16. In or recelve funds and technical assistance from any state or federal programs,

17. especlally as those programs relate to envirommental protection, conservation, land

18. use planning, water and alr quality control, economic development, transportation or

19. the development of region-wide public services. The comission may authorize debt

20. In anticipation of receipt of revenue as provided in section four.

21. SECTION 4. The commission shall annually in the month of January esctmate the

22. anount of money required to pay its total expenses for the following fiscal year,

23. deduct estimated contributions from sources, and pro rate the net expenses to eaih

24. Lown on the basis of its latest equalized valuation for property tax purposes as

25. established pursuant to section nine of chapter fity-eight of the General Laws. The

26. commisaion shall certify the amount so determined to the town clerk and s.isessors

27. of each town within the commission's juriadiction who shall include the sum In the

28. tax levy of the year.

29. Upon order of the commission, each town treasurer shalj, subject to che provisions 1 
1. of sections fifty-two and fifty-six of chapter forty-one of the General laws, pay to

2. the comalssion clerk-treasurer the town's share of the coinmission's net expenres.

3. The amount so deterwined and levied shall not exceed .036 per cent of the latest

4. equalized valuation for each town. A penalty of elght per cent per annum shall be

5. paid by towns delinquent in paying their assessed approprtations to the cormission if

6. not pafd within sixty days of the notice of payment due.

7. The comomission may recelve for the purposes of this act any funds or monles

8. from any source, Including grants, bequests, gifts or contributions made by any Indi-

9. vidual, assoctation, corporations, or by municlpal, county, state, or federal govern-

10. ments. Monles so recelved shall be disbursed by the clerk-treasurer of the com.lssion

11. upon an order voted by the commlsston; and the charges upon all towns may be reduced

12. correspondingly upon a majority vote of all members if sucli monles ware not included

13. In the calculations of the town's net share of expenses for the fiscal year.

14. The commission may authortze lebt by a mafority vota of the comaisston in anti-

15. cipation of revenue to an amount not in excess of that to be received durlng the

16. current fiscal year from all federal, state, county and local suurces. Notes issued

17. under authority of this mection shall be signed by the clerk-treasurer of the com-

18. mission, and the chairman of the commission shall countersign and approve them In

19. the presence of the vice-cheirman of the commission who shall certify to the fact on

20. the face thereof. Such notes shall be payable, and shall be pald, not later than

21. one year from their dates, and shall not be renewed or pald by the 1ssue of new notes,

22. except as provided in section seventeen of chapter forty-four of the General Laws.

23. The commission shall record all recelpts and disbursements in accordance with

24. the requirements of the commonwealth which govern accounting practices for cowns.

25. All personnel, material and service charges shall be kept separately and allocated

26. to efther direct or Indirect accounte by project or program. Complete annial account-

27. Ing reports, prepared in the manner prescrlbed for towns, shall be publist..- and dis-

28. tributed within ninety days after the-end of each fiscal year. Coples of sald annual

29. accounting reports shall be made avallable to the publle and coples shall be sent 
1. to the town clerks and the finance comittees of each town in the county of Dukes

2. County.

3. SECTIOW 5. Notw1thstanding the provistons of any ordinance or by-law of a

4. municipality on Martha's Vineyard, every munletpal land regulatory agency shall be

5. governed by the procedures, standards, and eriterla established pursuant to this

6. act in passing on applications for development perwits relating to areas and develop-

7. ments subfect to this act. A copy of each such perait granted by any such agency

8. shall be flled with the cormission.

9. Where there 1s a conflict between a local rule, regulation, ordinance, by-law

10. or master plan, the more liniting or restrictive requirement shall prevall.

11. SECTION 6. The following words, wherever used in this act shall, unlesi the

12. context requires otherwise, have the following meanings:

13. "Developwent", any bu1lding, mining, dredg1ng, filling, excavation, or drilling

14. Operation; or ny material change in the use or appearance of sny structure or in

15. the land 1tself; or the dividing of land Into parcels; or a change in the intensity

16. of use of land, such as an increase in the number of dwelling units in a structure:

17. or alteration of a shore, beach, seacoast, river, stream, 1ake, pond, or canal, In-

18. cluding coastil construceion; or demolition of a stucture; or the clearing of land

19. as an adfunct of construction; or the deposit of refuse, solid or liquid waste or

20. f111 on a parcel of land.

21. "Development ordinaaces and by-1aws", any by-law, ordinance, rule, regulation,

22. or code adopted by a municipality for the control or regulation of activities related

23. to construction, Improvement, or alteration made to bulldings or land within the

24. boundartes of sald munlcipality.

25. "Developwent permit", any permit, 11cense, authority, endorsement, or peraission

26. required from a municipal agency prior to the comencement of construction, 1mprove-

27. ment, or alteration made to bulldings or land.

28. "Muntelpal land regulatory ageney", any munictpal agency, board, comission,

29. department, office, or offletal that has statutory authority to approve or grant a 
1. development permit.

2. "Person", an IndIvidual, corporation, governmental agency, business trus.t,

3. estate, trust, partnership, association, two or more persens having a foint or com-

4. mon Interest, or any legal entity.

5. "Regulation", any ordinance, by-law, rule, regulation or code which may be

6. adopted by a city or town under the General Laws enumerated in section three of this

7. act and which 1s adopted or approved by the commisston under the provistons of sec-

8. tion ten.

9. SECTION 7. The comission shall subalt to the secretary of the executive office

10. of enviromental affairs standards and criteria which the commission proposes to use

11. In determining whether or not a proposed area 18 one of critlcal planning concern as

12. that term 1s defined in section eight; and atandards and criterla which the commission

13. proposes to use and to be used by municipal authorittes in determining whether or not

14. a proposed developaent is one of regional impact as that term 18 defined in section

15. twelve.

16. The secretary of the executive of fice of environmental affairs, with the con-

17. currence of such other menbers of the governor's cabinet as the governor shal.1 desig-

18. nate for this purpose, way approve, dieapprove, or amend and approve with the advice

19. and consent of the comalseton, the standards and criterla regarding designation of

20. districts of criticsl planning concern and review of developments of regionsi latpact

21. If such standards and criteria are in accordance with the purposes of the comisaton.

22. The secretary of the executive of fice of environmental affairs and such other - binet

23. members designated by the governor shall approve, disapprove, or amend 1 ' appl 'e

24. standards and criteria submitted to then within forty-five days after the -ecelpt of

25. such standards and criteris.

26. The standards and criterla submicted by Martha's Vineyard Conmissior stablished

27. under chapter $1 x$ hundred and thirty-seven of the acts of nineteen hundred and seventy-

28. Eour, and by the secretary of communities and development on September eighth, nineteen

29. hundred and seventy-five shall be deemed in full compllance with this section and 1, 
1. shall continue in full force and effect unt1l such time as they are amended by the

2. commission and approved, or anended and approved, by the secretary of the executive

3. office of environmental affalrs in accordance with this section.

4. SECTION 8. The comanission may, after notice to all municipalities which include

5. within their boundarles any part of the area of a proposed district of critical plan-

6. ning concern and after notice and public hearing pursuant to section two of chapter

7. thirty A of the General Laws, designate specific geograph1cal areas on Martha's VIne-

8. yard as districts of critlcal planning concern. The designation of such districts

9. shall be made only in accordance with the standards and criterla for districts of

10. critical planning concern approved purguant to section seven.

11. A district of critical planning concern may be designated only for (a) an area

12. which possesses unique natural, historical, ecological, scientific, or cultural

13. resources of regional or statowide significance; (b) an area which possesses marginal

14. soll or topographic conditions which render 1t unsuitable for intense development;

15. or (c) an area ignificantly affected by, or having significant impact on, an existing

16. or proposed mafor public facllity or other area of major public investment. A major

17. public facility is any publicly owned facllicy of reglonal importance except:

18. (1) any public facility operated by a munigipality primarily for the benefit

19. of the residents of that municipality, or by any agency serving primarily the residents

20. of one municipality;

21. (2) any street or highway which 1s not recognized as or maintained as a part of

22. the state or federal highway system; or

23. (3) any educational Institution serving primarily the residents of one aunic1-

24. pality.

25. Womination of areas for consideration for designation as districts of critical

26. planning concern may be wade by the commission or by a board of selectmen, planning

27. board, board of health, or conservation comblsation of any of the towns affected by

28. this act for any area within or without 1ts municipal boundaries. Nominations also

29. may be made upon petition of seventy-five taxpayers of any town on the Is land. 
1. Within forty-five days of the recelpt of a mination the comission shall aceept

2. or refect the nomination for consideration for designation upon a majority vote of

3. Its menbers. The acceptance of the nomination for consideration for designation

4. shall be accompanied by a general statement of purpose, describing the renscins for

3. acceptance of the nomination for consideration. Nominations which are not accepted

6. for consideration shall be returned to their sponsors with a written explanation of

7. the commission's reasons for not accepting the nomination within forty-five days of

8. submission. The commission may consolidate nominations which pertain to tra same

9. geographical area or to areas which are contiguous or 1t may amend a nomination.

10. Nominations accepted for consideration for designation which do not recefve designa-

11. tion way be reconsidered for designation within one year of the original acceptance

12. for consideration upon a vote of two-th1rds of the commission nembers.

13. In its designation of a district of critical $\mathrm{R}$ lanning concern the commission

14. shall specify why the area is of critical concern to the region, the problems a- ro-

15. ciated with the uncontrolled or Inappropriate development of the area, and the advan-

16. tages to be gained from development of the area in a controlled manner. The commis-

17. Sion also shall specify broad guidelines for the development of the district. "The

18. 1ssuance of such guidelines shall be based on, but need not necessarily be Ilmited

19. to, the following considerations:

20. (a) that development of the district will not result in undue water, alr, land,

21. or noise pollution, taking Into account the elevation of the district above sea level,

22. the nature of the so11s and subso1ls and the1r ab1lity adequately to support waste

23. disposal, the slope of the land and its effect on effluents, avallability of streams

24. snd other condufts for disposal of effluents, and the applicable health, water re-

25. sources and environmental regulations;

26. (b) that the existing water supply of the district will not be unreasonably

27. burdened by any development;

28. (c) that development of the district w11l not result in increased beach erosion

29. or danage to the 11ttoral or wetlands environments;

30. (d) that development of the district will not result in undue harm to c.ilcural, 131. economic, or h1storic values. 
1. In any application for a development permit which applies to an area within a

2. district of critleal planning concern, the burwen of proof of compliance whth the

3. above considerations shall be on the applicant. The comission may amend or rescind

4. the designation of a district in the manner provided for designation.

5. Nominations accepted for consideration for designation which do not receive

6. designation from the commission within sixty days of the date of acceptance shall be

7. retumed to their sponsors with a written explunation of the commission's reasons for ne

B. granting the designation.

9. SECTION 9. No municipality shall grant a development permit applicable wlthln

10. a district of critical planning concern except In accordance with regulations promul-

11. gated pursuant to section ten.

12. The acceptance of a nomination for consideration for designation of a district

13. of critical planning concern shall suspend the power of a mulucipality to grant de-

14. velopment permits applicable within the district; provided, however, that unt1l regu-

15. lations for the district adopted pursuant to section ten have become effective, a

16. mustictpality may grant development permits, applicable within the district if:

17. (a) the commission has certified that the type or class of proposed construction,

18. Improvement, or alteration is essential to protect the public health, safety, and

19. general welfare because of an existing emergency certifled by the commission; and,

20. (b) a development ordinance or by-law had been in effect Immediately prior to

21. the nomination of such area and development peralts would have been granted under

22. such ordinance or by-law.

23. SECTION 10, After designation of a district of critical planning concern, a

24. municipality whose boundaries include all or part of the district may adopt regula-

25. tions in conformance to the guidelines for the development of the district as set

26. forth in the designation. In adopting such regulations, each municipallty shall have

27. all of the powers it otherwise had under the General Laws. A copy of regulations so

28. adopted shall be submitted to the commission.

29. Pursuant to the issuance of broad guldelines for the development of the district 
1. by the comission in its desiguation of a district of criticisl planning concern,

2. four town boards, the town plauning board, the board of hcalth, the board of select-

3. men and the conservation commission shall prepare proposed regulations whlch con-

4. form to the guidelines. Sald proposed regulations shall be transmitted to the

5. comission by the boards of the town concerned.

6. If the commission determines that the proposed regulations, or regulations

7. amended by the commission, submitted conform to the guidelines for the development

B. of the district specified in the commission's designation of the district, the

9. comission shall, after notice to all municipalities which include wtthin their

10. boundaries any part of the district of critfcal planning concern and after notice

11. and public hearing pursuant to section two of chapter thirty $A$ of the General Laws,

12. notify the four cown boards of conformance to the guidelines. When boards from more

13. than one town shall, pursuant to this act, submit proposed regulations for areas

14. within a single district, the counission may encourage such boards to submit com-

15. patible regulations, notwithstanding the differences between the municipalities.

16. If the commission determines that sald proposed regulations are not in confor-

17. mance to the guidelines, the comission shall specify to the four town boards why

18. the regulations fall to conform to the guidelines. The four town boards may then

19. submit to the commission proposed amended regulations. Upon the approval. by the

20. costulssion of proposed regulations or proposed amended regulations, the munfe1?ality

21. In whose boundaries the district was designated, may adopt the regulations or amended

22. regulations by a two-thirds vote on a town ballot, with discussion of the question

23. on the town meeting floor at the discretion of the moderator. A fallure to adopt by

24. a two-thirds vote of town meeting constitutes a refection of regulations.

25. If a municipality whose boundarles include all or part of the distri: falls

26. to subalt regulations which conform to the guidelines for the development of the

27. district within six months after the designation, the commission may after wntice to

28. such municipality and notice and public hearirg pursunt to section two of chapter

29. thirty A of the General Laws, adope regulations applicable to such municipality's 1. 
1. portion of the district.

2. The adoption of such regulations shall specify the extent to which they shall

3. supersede the otherwise applicable local devel ipment ordinances and by-laws or be

4. supplementary thereto. Regulations so adopted shall be only the types specifled in

5. section three.

6. All regulations so adopted shall be incorporated, without regard to the provl-

7. sions of section thirty-two of chapter forty of the General Laws, by the municipality

8. Into the official ordinances, by-laws and maps of the municipality and shall not be

9. effective prior thereto. Such regulations shall be administered by the municipality

10. as If they were part of 1 ts development ordinances and by-laws. If such a regula-

11. tion requires enforcement by an administrative of fice or body which has not been

12. constituted by a municipality, the board of selectmen of the munfelpality shall en-

13. force such regulation. At any time after the adoption by the commission of such

14. regulations, the munletpality concerned may adopt regulations which, if approved by

15. the commission as provided in this section, shall supersede any regulations adopted

16. by the cominission pursuant to thls section.

17. A municlpality may rescind regulations th the manner provided. The process to

18. rescind regulations may be initiated by a written request by the comission or by

19. the board of selectmen, planning board, board of health, or conservation commisglon

20. of the town affected, or by a petition of seventy-five island caxpayers.

21. The writcen request for rescission shall be presented to the following four town

22. boards: board of selectmen, planning board, board of health, and conservation comm1s-

23. sion. The four town boards shall hold a public hearing with due notice.

24. Following the hearing, the boards shall transult to the commission, $\varepsilon$ recommenda-

25. tion for its consideration. The commission shall hold a public hearing with due no-

26. tice and shall make a recommendation for town meeting consideration.

27. The board of selectmen of the town concerned thall place upon the town ballot a

28. question regarding rescinding of regulations. Regulations shall be rescinded by a

29. two-thirds vote on a town ballot, with discussion of the question on the town floor 
1. by discretion of the moderator, or at a special hearing called for the purpose by

2. the board of selectmen in which town the question will take place. Regulations so

3. rescinded shall immediately be removed from the local development ordinances and

4. by-laws and shall not be supplementary thereto.

5. SECTION 11. If the conmission has not approved or adopted regulations appli-

6. cable to the entirety of a district within twelve months after designation of such

7. district, the designation of such part for which regulations have not been approved

8. or adopted shall be terminated. No part of the area formerly designated as a dis-

9. trict shall again be designated as a district for a period of tweive months firom the

10. date of such termination. Notice of such termination shall be given in the same man-

11. ner as provided for designation.

12. SECTION 12. The commission shall adopt and submit for approval, pursuant to

13. section seven, standards and criterla which specify the types of development which,

14. because of their magnitude or the magnitude of their effect on the surrounding en-

15. vironment, are 11kely to present development issues slgnificant to more thin one

16. municipality of the 1sland of Martha's vineyard. For the purpose of this act, such .

17. types of development shall be termed developments of regional impact.

18. Notice shall be given by the compisaton at least fourteen days prior to $a$

19. pub1ic hearing on amendments to the criteria and standards for development of tegional

20. Impact.

21. Sald notice shall be given by certifled mall by the commission to but not $11 \mathrm{mited}$

22. to the following town boards or officlals of each town on Martha's Vineyard: board

23. of selectmen, board of health, planning board, bullding officlal, conservation com-

24. mission, and board of assessors.

25. Within ninety days following the public hearing the commission shall consider

26. changes to the standards and criteria, which shall be submitted in accordance with

27. section seven.

28. In adopting standards and criterla pursuant to this section, the commirition

29. shall consider, but shall not be limited by the following constderations: 
1. (a) the extent to which a type of development would create or alleviate

2. environmental problems, Including, but not 11mited to, air, water, and noise

3. pollution;

4. (b) the size of the site to be developed;

5. (c) the amount of pedestrian and vehicular traffic likely to be generated;

6. (d) the number of persons likely to be residents, employees, or otherwise

7. present;

8. (e) the extent to which a type of development is incended to serve a regional

9. market;

10. (f) the location of a type of development near a waterway, publicly-owned

11. 1and, or a muntcipal boundary; and

12. (g) the extent to which the development would require the provision of the

13. following muntelpal or reglonal services: solld waste disposal, public water

14. supplies, sewage treatment facilities, parking facilities and courist aervices,

15. and public educacion facilities.

16. The standards and criterla shall be reviewed at least every two years.

17. SECTION 13. The governmental agency within each municipality wh1ch has re-

18. sponsibllity for fssuing a development permit shall in accordance wich the stand-

19. ards and criteria approved pursuant to section seven determine whether or not a

20. proposed development, for which application for a development permit has been

21. made, is one of regions 1mpact; if so, it shall refer the application for the

22. development permit to the comission.

23. SECTION 14. The comission shall review all applications for development per-

24. mits for developments of regional impact. Notice and public hearing pursuant to

25. section two of chapter thirty A of the General Laws shall be required, except

26. that only fourteen days rather than twenty-one days of prior notice shall be

27. required and a copy of said notice need not be sent to the state secretury. The

28. commission ohall permit the referring agency to grant a development permit for

29. such development only if it finds after such public hearing that: 
1. (a) the probable benef1t from the proposed development will exceed the

2. probable detriment as evaluated pursuant to section fifteen;

3. (b) the proposed development will not substantially or unreasonably inter-

4. fere with the achlevement of the objectives of the general plia of any municipality

5. or the general plan of the cointy of Dukes County;

6. (c) the proposed development 18 consistent with municipal development ord1-

7. nances and by-laws, or, If it is inconsistent, the Inconsistency is necessary to

8. enable a substantial segment of the population of a larger conmunity of which the

9. municipality is a part to secure adequate opportunities for housing, education or.

10. recreation; and

11. (d) If the proposed development is located in whole or in part within a

12. designated district of critical planning concern, it is consistent with the regu-

13. Lations approved or adopted by the comnlssion pursuant to section ten.

14. The comission shall hold the public hearing within thirty days after recefpt

15. of the referral, or application. The commission shall make the required finding

16. and potify the referring agency and applicant of its decision within sixty days after

17. the public hearing. These time limits may be waived by mutual agreement between

18. the comission and the applicant for the development.

19. SECTION 15. In making a finding of the probeble benefits and detriments of

20. a proposed development, the commission shall not restrict 1ts consideration to

21. benefits and detriments within the municipality of the referring agency, but shall

22. cons1der also the impact of the proposed development on the areas wthin other

23. municipalities. Such probable benefits and detriments shall be considered nven 1 :

24. they are 1ndirect, 1ntang1ble or not read1ly quantifiable. In evaluating the prob-

25. able benef 1 ts and detriments of a proposed development of reglonal Impact tho com-

26. mission shall consider, together with other relevant factors, whether:

27. (a) developwent at the proposed location is or is not essential or especial-

28. Iy approprlate in view of the avallable alternatives on the 1aland of Martha's Vine-

29. yard; 
1. (b) development In the manner proposed 111 have a more favorable or adverse 2. impact on the environment in comparison to alternative manners of development;

3. (c) the proposed development will favorably or adversely affect other persons

4. and property, and if so, whether, because of circumstances pecullar to the location,

5. the effect is likely to be greater than is ordinarily associated with the development

6. of the types proposed;

7. (d) the proposed development w11l favorably or adversely affect the supply

8. of needed low and moderate Income housing for island residents;

9. (e) the proposed development will favorably or adversely affect the provision

10. of municipal services and the burden on taxpayers in making provision there for;

11. (f) the proposed development will use efficiently or burden unduly existing

12. public facllities or those which are to be developed within the succeeding five years;

13. (g) the proposed development w11 ald or Interfere with the ability of che

14. municipality to achieve the objectives set forth in the municipal general plan; and

15. (h) the proposed development w1ll further contravene land development objec-

16. tives and policies developed by reglonal or state agencles.

17. Whenever the comission 13 required to find whether the probable benefit from

18. a proposed development of regional impact w11 exceed the probable detriment, $1 t$ shall

19. prepare a written opinion setting forth the grounds of 1 ts findings.

20. SECTION 16. No referring agency shall grant a development permit for develop21. ment of regional impact except with the permission of the commission. In permitting 22. the referring agency to grant a development permit for a development of regional im-

23. pact the comalssion may also specify conditions to be met by the developer to whom

24. the permit is being 1ssued for the purpose of minimizing econowic, social, or environ-

25. mental damage.

26. SECTION 17. The commission may enforce any decisions, conditions or restrictions

27. It may impose upon a development by recording certificates of noncompliance with

28. appropriate plan or title references in the registry of deeds. The comaission may

29. commence such other actions or proceedings as it may deem necessary to enforce its 
1. decisions, conditions or restrictions.

2. SECTION 18. Any party aggrieved by a determination of the commission may

3. appeal to the superior court within twenty days after the commission has sent the

4. development applicant written notice, by certifled mall, of 1ts decision and has

5. filed a copy of 1ta decision with the town clerk of the town in which the proposed

6. development is located. The court shall hear all pertinent evidence and shall anul

7. the determination of the commission if it finds that sald determination is unsup-

8. ported by the, evidence or exceeds the authority of the commission, or it may remand

9. the case for further action by the commission or may make such other decree as is

10. Just and equitable. Costs of the appeal shall not be allowed against the commission

11. unless 1t shall appear to the court that the comission acted with gross negligence,

12. bad falth or mallce. Costs of such appeal shall not be allowed against the appellant

13. unless it shall appear to the court that the appellant acted in bad falth or with

14. malice.

15. SECTION 19. In addition to performing its functions under this act, the com-

16. mission may perform any function assigned to it under federal law.

17. SECTION 20, All pet1tions, hearings, and other proceedinge duly brought before,

18. and all prosecutions and legal and other proceedings duly begun by, any person, mu-

19. nicipal land regulatory agency, local board or officlal or the Martha's Vineyard Com-

20. mission, established by chapter six hundred and thirty-seven of the acts of ntheteen

21. hundred and seventy-four, as amended, which arise from or relate to the exercise

22. of powers or the performance of dutles under sald chapter six hundred and thirty-

23. seven and which are pending or Incomplete Imediately prior to the effective date

24. of this act, shall continue unabated and remain in full force and effect notw:th-

25. standing the passage of this act, and shall thereafter be completed in accordance

26. with this act.

27. All orders, actions, guldelines, standards, and criterla, designations, pro-

28. cedures, by-laws, development ordinances and by-laws, regulations, conditions and

29. modiflcations and declsions duly made, and all I1censes, permits, authorities, 
1. pernissions, certificates, approvals and endorsements duly granted, by any munici-

2. pal1ty, municlpal land regulatory agency, local board or officlal of the sald

3. Martha's Vineyard Comission, as so established, which arise from or relate to the

4. exercise of powers or the performance of duties under sald chapter six hundred and

5. thirty-seven and which are in effect imediately prior to the effective date of this

6. act, shall continue in full force and effect and the provisions thereof shall there-

7. after be enforced, unt1l superseded, revised, rescinded or cancelled in accordance

8. with this act and any other applicable law.

9. SECTION 21. Al1 books, papers, records, documents, equipment, lands, interests

10. In land, bulldings, fac1lities and other property, both personal and. real, wh1ch

11. Lmediately prior to the effective date of thls act, are in the custody of the Mar-

12. tha's Vineyard Commission, established by chapter six hundred and thirty-seven of

13. the acts of ninetcen hundred and seventy-four, as amended, and which relate to or

14. are maintained for the purpose of the exerclse of powers or the performance of dutles

15. under sald chapter $\mathbf{s i x}$ hundred and thirty-geven are hereby held by the Martha's

16. Vineyard Commission established under the provisions of this act.

17. SECTION 22. A11 duly exist1ng contracts, leases and ob11gations of the Mortha's

18. Vineyard Comission, established by chapter $s 1 x$ hundred and thirty-seven of the acts

19. of nineteen hundred and seventy-four, as amended, which relate to the exerc1se of

20. powers or the performance of dutles under said chapter $s 1 x$ hundred and thirty-seven

21. shall hereafter be obligations which are assumed and performed by the Martha's Vine-

22. yard Comission established under the provisions of this net.

23. SECIION 23. All assessments made by the Martha's Vineyard Commission esta-

24. bl1shed by chapter $81 x$ hundred and thirty-seven of the acts of nineteen hundred and

25. seventy-four, as amended, and all monies heretofore recelved or to be recelved from

26. any source by sald commission for the performance of 1ts duties and which remaln un-

27. expended on the effective date of this act shall immedlately be transferret to the

28. Martha's Vineyard Conmission established under the provisions of this act and shall

29. be avallable for expenditure by sald comission. Any such assessments unpald on the 
1. effective date of this act shall be due and owing to the Martha's Vineyard Comis-

2. sion established under the provisions of this act.

3. SECTION 24. The members of the Martha's Vineyard Comm1ssion established by

4. chapter six hundred and thirty-seven of the acts of nineteen hundred and seventy-

5. four, as amended, in office on the effective date of this act shall continue in

6. office as members of the Martha's Vineyard Commission established by this act for

7. the duration of the term for which they were originally elected or appointed.

8. All employees of the Martha's Vineyard Commission established by sald chapter

9. $81 x$ hundred and thirty-seven 1mediately prior to the effective date of this act

10. shall be transferred to and become employees of the Martha's Vineyard Commission

11. established by this act. Such transfer shall be without impalrment of seniority,

12. retirement, or other rights or benefits accruing to the employees and without In-

13. terruption of service or reduction in compensation or salary grade.

14. SECTION 25. Chapter six hundred and thirty-seven of the act: of nineteen

15. hundred and seventy-four, as most recently amended by chapter two hundred and $n$ Lne-

16. teen of the acts of nineteen hundred and seventy-s $1 x$, is hereby repealed.

17. SECTION 26. The provisions of this act ure severable, and if any of 1ts

18. provisions shall be held unconstitutional or Invalid by any court of competent

19. Jurisdiction, the decision of such court shall not affect or 1mpalr any of the re-

20. maining provisions.

21. SECTION 27. Th1s act shall take effect upon its passage. 12/21/77

22. (This draft 1ncorporates the amendments of Chapter 319 of $6 / 25 / 79$. ) 


\section{THE MARTHA'S VINEYARD COMMISSION}

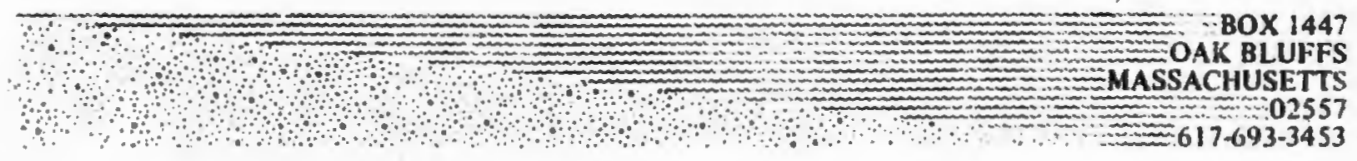

DISTRICTS OF CRITICAL PLANNING CONCERN REGULATIONS FOR THE TOWN OF EDGARTOWN - ADOPTED BY THE MARTHA'S VINEYARD COMMISSION

\section{A Administration}

1. These regulations are overlay requlations. Overlay regulations are separate regulations which are superimposed over existing zoning districts, zoning regulations, health regulations, conservation regulations and other land use regulations affecting the town. These overlay regulations are supplementary to such existing regulations. Where there is a conflict the more limiting regulations shall prevail. These regulations apply to all land, all development, all uses and all permits and approvals within the following districts: Coastal District, Island Road District and Special Places Districts, (the "Districts").

2. For applications for Special Permits within Districts, where the Zoning By-Law does not specify a Special Permit Granting Authority, the Planning Board shall be the Special Permit Granting Authority.

a. Prior to granting a Special Permit within the Districts, the special Permit Granting Authority shall determine that the proposed development complies with the goals of the appropriate District and assures protection against adverse environmental impact including the following where applicable.

-pollution of surface or ground water or of water bodies:

- galt-water intrusion of public or private domestic water supply wells:

-inadequate water supply to meet the anticipated demand of the proposed activity or use or reduction of or interference with water supply available to other properties;

-air and noise pollution:

-destruction of wildlife habitats and damage to wetlands or littoral ecology;

-damage to marine fisheries and shellfish;

-unnecessary interruption of the visual amenities of the site by construction which is not in harmony with the landscape type;

-erosion resulting from or caused by development; 


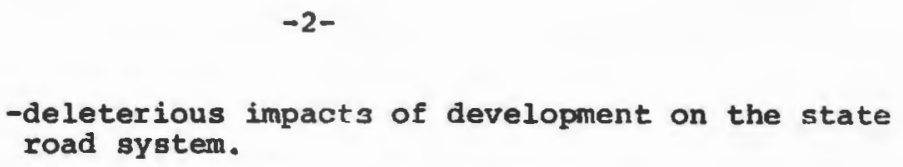

In granting a Special Permit, the Special Permit' Granting Authority may impose such conditions and safeguards as it deens appropriate.

b. All special Permits applicable within the Special

Places and Coastal District shall be reviewed by

the Plan Review Comnittee. The Special Permit Granting Authority shall refer applications to the Comittee for this purpose. The Plan Review Committee's report to the Special Permit Granting Authority shall be in writing, and comment on how the application conforms to the goals of the Distict and the guidelines for decision which the Special Permit Granting Authority must consider.

Failure of the Plan Review Committee to report to the Sperial Permit Granting Authority within 1: days after receipt of the application, shall be construed as a recommendation of Approval:

The Plar Review Committee is established by order of the relectman and consists of a member from and appointed by at least two of the following organizaticos: Conservation Commission. Board of Selectmen, Planning Board, Martha's Vineyard Comission, Building and Zoning Inspector. Until the: Plan Review Comnittee is so established the Boarc of Selectmen is the rlan Review Committee.

B. The Coastal District

1. The Coastal District includes the land, streams and wetlands of Edgartown whicl lie below ten (10) foot elevation above mean sea level, or within five-hundred (500) feet or. mean high water of a coistal water body exceeding ten (10) acres, or the ocean: all land within one-hundred (100) feet of streams and wotlands draining into the coastal Great Ponds.

Exemption: Ttie land bounded on the south by Atwood Circle extended to Eugartown llarbor; on the north and east by the walkway to the Lirghthouse and North water street to starbuck Neck Road and iaines Wav to where it intersects the ten (10) foot contour 1:ne.

2. Goals of the Co.3stal D1sitrict

The goals of til coastal vistrict are to: prevent flood damage, maintai: vater quasty and supply, prevent pollution, promote wildlife habiteis, protect eultural and historic sites, protect: the charzoter of views, prevent damage to structures, land and water 33 a result of erosion, promote the developrent of the Islind economy.

3. Establishnent of :onis ir the Coustal Distri:t a. Shore zone: Consisting of the land from mean low 
water to one-hundred (100) feet inland of the inland edge of any beach ur marsh grasses, and one-hundred

(100) feet inland of the crest of any bluff exceed-

fing a height of fifteen (15) feet, or within 100

feet of any stream or wetland draining into a coastal

great pond. A bluff shall mean land adjacent to a

beach or coastal wetlands which shows the effects

of wave erosion or other down slope erosion causing

it to be steeper than the dtherwise natural slope of the land.

b. Inland zone: Consisting of all land within the Coastal District except the Shore zone.

4. Permitted Uses

a. Shore zone: Only those uses permitted in section 13.4a of the zoning by-law, and which are consistent with the fragile nature of the area, such as outdoor recreation, agriculture, fishing and conservation purposes.

b. Inland zone: All uses permitted in the Shore zone as well as detached single fanily dwellings and non-habitable minor accessory structures normally used for personal, family and household purposes: subject to the restriction of section $B .6$ of these regulations and of the underlying zoning district.

5. Uses Allowed by Special Permit

The Special Permit Grantinq Authority may grant a Special Permit in accordance with Section $A$ of these regulations.

a. Shore zone: As in Sectini 13.4.b. of the zoning By-law except that municipal uses must be associated with beach stabilization or drainage profects.

b. Inland Zone: Uses allowed by permit or special permit by the zoning By-law subject to the requirements of B.6 of these regulations.

6. Regulations and Restrictions

The regulations and restrictions of the respective underlying zoning District shall apply, subject to the following:

a. Height of structures

Maximum height of structures as measured vertically from the mean natural grade level shall be as follows: 24 feet for a pitcned roof and 13 feet for a flat or shed roof (which is a roof with a pitch of 1 in 4 or less).

The Special Permit Granting Authority may grant a special Permit, in accordance with the provision of 
Section A., to modify the height restrictions of the coastal District, up to the maximum allowed in the underlying zoning District.

b. Except by Special Permit, no road shall exceed ten (10) feet in width.

c. Except by Special Permit, all utility installations shall be placed underground.

d. Any ground water well shall require a permit from the Board of Health before installation, and shall be located at least two-hundred (200) feet from any sanitary disposal facility, and two-hundred (200) feet from any salt water body.

e. Any sanitary disposal facility shall be located a minimum of two-hundred (200) feet from any salt water body.

f. There shall be a minimum separation of two-hundred (200) feet between sanitary disposal facilities.

g. No portion of a sanitary disposal facility shall be located less than five (5) feet above minimum ground water elevation.

h. No sanitary disposal facility shall be located less than six-hundred (600) feet from a public water supply well nor less than two-hundred $(200)$ feet from any domestic water supply well.

1. Where compliance with these regulations is not possible due to the dimensions of a lot existing in separate ownership from adjoining lots befove December 22,1976 , the requirements (e-i) may be modified by the Board of Health.
\end{abstract}


C. Island Road District

1. Major Roads; consisting of the area lying within twohundred (200) feet of the right of way of the following roads;

- the West Tisbury-Edgartown Road from the Chase Road intersection west to the town boundary.

- the Beach Road from the intersection with the Edgartown-Vineyard Haven Road north and north westerly to the Town boundary.

- Chappaquiddick Road, to and including Wasque Road, School Road and Dyke Road, from the ferry landing to the boundary of the Trustees of Reservation's property.

- Katama Road from the intersection with Herring Creek Road south to and including Atlantic Drive.

- Herring Creek Road.

- the Edgartown-Vineyard Haven Road from its intersection with the Beach Road, westerly to the town boundary.

2. Goals of the Island. Road-District

The goals of the Island Road District are to: allow for safe access and travel along the roads; protect the visual character, and historic features along the roads, and maintain and enhance the state Road system.

3. Permitted Uses

Any residential (including home occupational), business, recreational, agricultural or open space uses as permitted in the respective zoning District subject to the regulations and restrictions set forth in section $C$. of these regulations.

4. Regulations and Restrictions

a. No stone wall shall be moved, removed or otherwise altered, except for repair, except for Special Permit of the Planning Board.

b. For all new accesses, applications must be made to the Planning Board.

c. Any additional vehicular access to the public road imust be at least 1,000 feet, measured on the same side of the road from any other vehicular access, except that if this requirement would prevent at least one (1) access to a public road from each lot held in separate ownership from the lots 


$$
-\therefore
$$

contiguous thereto as of December 22,1976 , each such lot shall be allowed a single acress which shall be located as far as practicable from all other such ways located on either side of the road except where arrangements have bean made to share existing accesses.

No land shall hereafter be divided, or sold, if such lot or lots would not be entitled to a way to provide vehicular access to a public way as provided herein.

The Planning Board may grant a special Permit to allow accesses at a closer interval than provided herein.

d. Height of structures

Except by Special Permit, the maximum height of structures as measured vertically fxom.the mean natural grade level shall be as follows: 24 feet for a pitched roof and 13 feet for a flat or shed roof (which is a roof with a pitch of $I$ in 4 or less). 


\section{THE MARTHA'S VINEYARD COMMISSION}

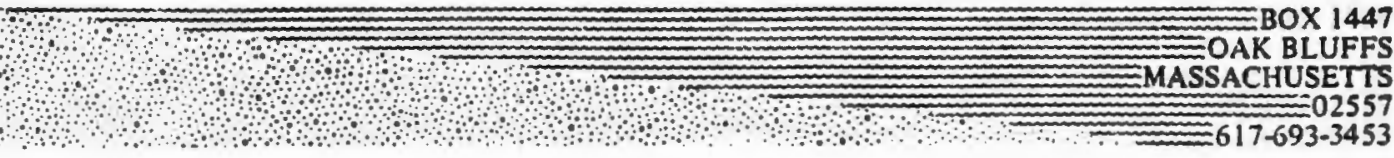

DATE :

June 7, 1979

TO:

Conservation Commission of the Town of Tisbury

FROM : Martha's vineyard Commission

SUBJECT: DEVELOPMENT OF REGIONAL IMPACT DECISION RE: COASTAL CONSTRUCTION

APPLICANT: Woods Hole, Martha's Vineyard, and Nantucket Steamship Authority

\section{SUMMARY}

The Town of Tisbury Conservation Comnission (the "Conservation Commission") is hereby permitted to approve the Woods Hole, Martha's Vineyard and Nantucket Steamship Authority's application for development permits provided that such permits are limited with regard to ferry slips to reconstruction of the existing vineyard haven terminal ferry slip, and in accordance with the conditions contained herein. The Conservation Commission may, if authorized by local development ordinances and by-laws, place additional conditions upon the application for development permits or disapprove the application in its entirety.

DECISION OF THE MARTHA'S VINEYARD COMMISSION

On December 26, 1978, and January 31, 1979 the Woods Hole, Martha's Vineyard and Nantucket Steamship Authority (the "Applicant") filed with the Conservation Commission an application for development permits for a coastal construction approval in the Town of Tisbury (the "Application"). The Application was set forth in Notices of Intent dated December 26, 1978 and January 31, 1979 flled by John J. McCue, the Applicant's General Manager, together with a plan entitled "plan Accompanying Petition of the Woods Hole, Martha's Vineyard and Nantucket Steamship Authority - To reconstruct and malntain existing pier, transfer bridge and dolphins, and to construct and maintain a reserve slip with a transfer bridge, dolphins and dredging for the Vineyard Haven Terminal of Vineyard Haven Harbor, Town of T1sbury, County of Dukes, Mass. - Sheets 7/7 12/13/78 - prepared and registered by George L. Wey". By such 
plan and Notices of Intent, the Applicant proposes the reconstruction of the existing vineyard Haven terminal ferry slip and dock and the construction of a new standby ferry slip together with dredging at the Vineyard Haven jteamship Authority ferry teminal. Inasmuch as the Application is for development within vineyard Haven Harbor, will be within a water body of ten (10) or more acres, or within the ocean, is for the reconstruction and/or new construction of a facility designed to serve the residents of more than one town and is a development which will provide facilities for transportation to or from Martha's Vineyard, the Conservation Commission correctly determined that the Application is for a Development of Regional Impact under the Criteria and Standards for Developments of Regional Impact No.'s 3.501, 3.502, 3.60, and 3.701. Therefore, this Application was referred to the Martha's vineyard Commission (the "Commission") for approval pursuant to Chapter 831 of the Acts of 1977 (the "Act"). The Application was received by the Martha's Vineyard Commission on March 22, 1979.

Prior to receipt of this referral, the Commission had beell made aware by the Applicant of the proposed project by a letter dated August 9, 1978. That letter indicated that the Applicant's project is part of a larger proposal, and the Applicant cited the urgency of the reconstruction, the total projected proposal costs of $\$ 14,820,000$, its pending application for Urban Mass Transportation Act ("OMTA") funds and the need for $\$ 3,300,000$ for the reconstruction of the Vineyard Haven Wharf portion of the entire proposal. The Applicant had indicated at that time that in order to be eligible for UMTA funding, it needed to be incorporated within a transportation development plan for the region.

Having been made aware of the Applicant's anticipated proposal, the Commission on August 10, 1978 formed a Joint Transportation Committee, consisting of members of the Commission, representatives of the Applicant and other individuals, to consider the Applicant's overall proposal. In addition, in accordance with the Commission's mandate under the Act, the Commission in late 1978 was contacted by the Harvard Graduate School of Design - Graduate Student Workshop concerming the development's impacts, trends in Island travel, passenger volumes, auto volumes, employment, expenditures, auto accumulation on the Island, scheduling and fleet composition of the 
Applicant. Members of the School of Design have been working on determining the impacts of the Applicant's overall proposal since that date.

On February 14, 1979 the Joint Transportation Committee recommended approval of "the renovation of the Vineyard Haven Terminal including a permanent second slip with the understanding that there will not be a decrease in the utilization of the Oak Bluffs facility and there will not be a substantial increase in the utilization of the Vineyard Haven terminal during the summer season".

On April 19, 1979 the Applicant presented an on-site inspection of the proposed development for members of the Commission and its Land Use Planning Committee.

On April 19, 1979 a hearing was held before the Commission pursuant to the Act and Massachusetts General Laws Chapter 30A, Section 2, at 8:00 p.m. at the Commission's offices, Olde stone Building, New York Avenue, Oak Bluffs, Massachusetts, upon public notice to consider the Application. Benjamin Moore, Chairman of the Commission, chaired the hearing. The public hearing was opened by Mr. Moore and then moved to the Martha's Vineyard Regional High School, Edgartown-Vineyard Haven Road, Oak Bluffs, Massachusetts. Public notice had been provided in local newspapers regarding the change of the hearing location. Copies of the notice of public hearing, and notice relating to the change of location are incorporated herein.

The Applicant made a presentation in favor of the development by John J. McCue, its General Manager. Mr. McCue pregented a report entitled "Report on the Investigation of the Condition of the Vineyard Haven Steamship Terminal" prepared by George I. Wey, Engineering Consultant, and indicated that the reconstruction of the existing ferry slip would take approximately nine months and that the proposed second slip would be used during the reconstruction of the existing facility. Mr. McCue gave assurances to the Commission that the Applicant had no intention of increasing the level of service for the Island beyond that of the 1978 level, and stated that the Applicant would be pleased to place this condition in writing. George L. Wey, Engineering Consultant" for the Applicant, also spoke as to the need for reconstruction, the basic engineering designs and the information set forth in his report.

Opponents of the Applicant's proposal also testified. $M r$. 


\section{${ }^{4}$ BK $3669 P 575$}

Harry Weiss, Vineyard Conservation Society, spoke and reviewed traffic impacts which would result from the development making reference to the 1978 study of the five corners intersection prepared by Allen M. Voorhees and Associates, Inc. for the Town of Tisbury Traffic Committee. Mr. Weiss indicated that the consulants concluded that "in addition to significant demand levels, the intersection suffers from sub-standard roadway geometrics." The five corners intersection is the major terminus for the Applicant's auto traffic in the Town of Tisbury. IIr. Robert Fultz expressed concern about the increasing fuel costs and the Applicant's bonded indebtedness. West Tisbury Selectman John Alley favored use and winterization of the oak Bluffs facility and commended the Applicant for adding one summer boat trip to oak Bluffs and reducing one trip to Tisbury. James Weisman addressed concem for the architecture of the proposed terminal building. West Tisbury Planning Board Chaiman Ronnee Schultz discussed the long term impact of the projects relating to growth.

Mr. McCue responded to the opponents' testimony and discussed an alternative to the proposed development which would be use of the Oak Bluffs facility. However, Mr. Mccue said that in poor weather conditions that port could not be used.

Mr. David Dunham asked for alternatives in the event of a disaster. Mr. Robert Woodruff raised concern over conflicting statements regarding an additional passenger vessel from Hyannis. Mr. Douglas, an abuttor, discussed his site investigation from his skiff at low tide and his conclusion that the need for major reconstruction was unfounded. Mr. Arthur Danvers, Mr. Arthur Dixon, Mr. Kevin Coughlin, Mr. Greg Gonsalves, and Mrs. Judith Miller also raised questions concerning the Application.

There was a general discussion regarding a suggestion that a second slip not be built and that only the existing slip be repaired. Mr. McCue stated in response to this that if the commission found that construction of only one slip was permissible, the Applicant would go forward on that basis making whatever adjustments to its proposed plans as necessary.

There was no further testimony and the hearing was closed at $11: 30$ g.m.

The Application was placed on th.e Commission's agenda for its 
meeting of April 26, 1979 at which time the Harvard Graduate School of Design - Graduate Student Workshop made a presentation concerning development impacts. The presentation concluded that the ferry fleet was at seasonal capacity for automobiles and at $70 \%$ capacity for passengers and concluded that there was no impact from a second slip given the present fleet composition. On May 3, 1979 the Commission extensively discussed the Application and the Commission voted "to approve the DRI as proposed by the SSA to build a second slip while repairing the first slip and continued revitalization of the Vineyard Haven dock subject to conditions set forth by the MVC."

On May 10, 1979 the Commission reconsidered its action of May 3, 1979 and again reviewed the matter of automobile and pedestrian traffic volumes, financing of the project, including the assessment of reconstructions costs against the Island communities in the event of the Applicant's deficit, and the regional economic impacts resulting from potential increases in traffic. The commission was particularly concerned about future pressures upon the Applicant to use the second slip, if built, notwithstanding its present assurances that the Applicant would not increase the level of service beyond that of the 1978 level.

There was also discussion regarding a letter received by the Commission on April 23, 1979 from Craig J. Ringsbury, Chairman of the Board of Selectmen of the Town of Tisbury, which described the Board of Selectmen's support for the Applicant's proposal. Mr. James Lobde11, a member of the Board of Selectmen of the Town of Tisbury and Martha's Vineyard Commissioner, indicated that this letter was not from the Board of selectmen, and that the present Board opposed two slips in Vineyard Haven Harbor. Mr. David Ferraguzzi, Martha's Vineyard Commissioner representing the Oak Bluffs Board of Selectmen, Indicated that the oak Bluffs Board of Selectmen voted unanimously in opposition to the two slip proposal citing Oak Bluffs significance as a regional economic port and the possible long-term detriments to oak Bluffs arising from two slips in Vineyard Haven. Serious concern was also expiessed that the matter of freight shed location and type of service has not been resolved by the Applicant.

After extensive discussion the Commission reconsidered its 


\section{8K366it57\%}

vote of May 3, 1979 and voted "that the Commission approve the SSA DRI Application for UMTA funds to rebuild or replace the present transfer bridge and ramp in the shortest reasonable time and then to rebuild the adjoining dock with no second slip."

Pursuant to Sections 14 and 15 of the Act, the Commission has weighed the probable benefits and detriments of the Applicant's proposal, has considered each factor enumerated in those sections and has considered its own standards and criteria and is mindful of its obligations to concern itself with local economies and the special qualities that represent Martha's Vineyard. The Commission therefore finds that the probable benefits of the proposal will exceed the probable detriments only if the existing slip is renovated and no second slip is constructed and if the work proceeds at set. forth in this derisıon; it further finds that the probable benefits would not exceed the probable detriments if the develonment were to gn forward with constructinn of a second slip.

In evaluating the probable benefits and detriments the Comission has considered the long tem benefits of the construction of a single slip versus those of a second slip. Oak Bluffs and vineyard Haven serve as major points of entry to the Island during the summer season, and a single slip will insure that Oak Bluffs, which receives 128 of seasonal traffic, will remain economically viable as a port of entry and will continue to realize a reasonable economic activity attributable to steamship operations. Similarly, a single slip will insure that already serious vineyard Haven traffic conditions will not further degenerate and will possibly improve. The Commission has been deeply concerned about the future pressures on the Applicant to increase pedestrian and vehicular traffic to the Island and has considered the impact on local economies and the region that would result from increased traffic. Further, the development of a single slip will not effect the year round business activity of the Town of Tisbury inasmuch as ferry service to Oak Bluffs is not available beyond the fall of any year. The Comission has also considered alternative development in alternative locations around the Island. The Commission has weighed the cost of the alternative proposals and finds that a development which is more liniting in scale, which has fewer long term maintenance costs associated with it and which gives assurances 
for a mixed financing approach, better serves local, regional and state-wide interests than the Applicant's proposal for two ferry slips in Vineyard Haven. Obviously, restricting the Applicant to one ferry slip will reduce the cost of construction. In adartion, it two slips were to ve permitted, one slip would remain idle for at least nine months of the year. The Commission finds that this use of public funds, from wnatever source, is not sound from a local economy basis. The people of Martha's Vineyard are fiscally responsible for deficit spendina by the Applicant, and the people of Martha's Vineyard already have the lowest per capita income of any county in the Commonwealth of Massachusetts. The Island's people could not sustain the extra burden of solely financing the Applicant's proposal, and the recreational resort-tourist oase of the Island, which serves reqional and state-wide summer interest, would likely suffer.

The Commission also considered the Applicant's proposal to move the present services of handling freight on the vineyard haven dock to an off-site location. To date, however, the Commission has not received any assurances from the Applicant regarding location, type of service, volume to be handled or building form, material or size. Therefore, to assure continuing service to meet the needs of the Island businessmen and visitors and residents, and in order to insure the enhancement of sound local economies, the Commission has concluded that the present freight handing convenience must be maintained. The Commission, may, however, at some future date, and in accordance with the conditions of this decision, approve an alcernative proposal which is more clearly defined.

The Commission has also considered the unique cultural, aesthetic and historical values associated with this Application. The present proposal for structures lacks sufficient architectural detail from which to reach a conclusion as no sections, elevations, or perspectives have been provided. The structures represent a major arrival point to the port of Vineyard Haven and to the Island as a whole. The Commission is aware that as part of securing UMTA funding the Applicant intends to prepare more detailed engineering and architectural plans for the construction of a single slip. Therefore, as part of its approval, the Commission will review those future plans for the structures for traffic flow, design, and re- 
lated matters. However, such review process will not delay construction as proposed by the Applicant.

In light of the foregoing, the Comnission finds that the development proposal as approved will be more beneficial than detrimental when compared to alternative manners of development or development occurring in alternative locations.

The Commission finds that the proposed development is consistent with local development ordinances and by-laws to the extent it is required to having only the Application before it at this time. The Applicant must, consistent with this decision, apply to the appropriate Town of Tisbury officers and boards for any other development permits which may be required together with any development permits required by law.

The Commission finds that the Application as approved will not interfere substantially with the achievement of any general plan of the Town of Tisbury or of Dukes County or violate any local development ordinances and by-laws. Further, it will promote the enhancement of soind local economies.

The Commission hereby permits the Town of Tisbury Conservation Commission to grant applicable development permits to the Applicant consistent with the Commission's decision of May 10, 1979 to allow only the reconstruction of the existing slip, together with the other work set forth in the plan and Notices of Intent, all subject to the following conditions:

1. The Applicant shall maintain the "dolly freight" concept so that consumers and small businessmen can deliver and pick up freight with no loss of the convenience now provided by the dolly freight system.

2. No development permits shall be issued by the Town of Tisbury for the construction of structures by the Applicant until the Commission has reviewed the Applicant's plans and specifications identifying location, siting, materials, size, waste disposal and other criteria identified in the Commission's Information Lists for Developments of Regional Impact.

This decision is written consistent with the vote of the Commission of May 10, 1979. 


\section{…300}

Buysimin C. More

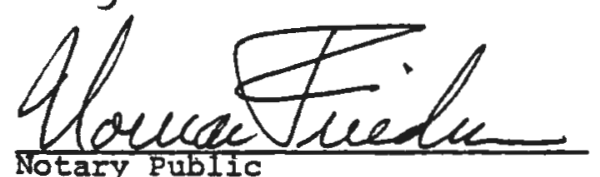

my comission expires: 11/10/83

$\frac{\text { JuWr } 12,1979}{\text { datte }}$

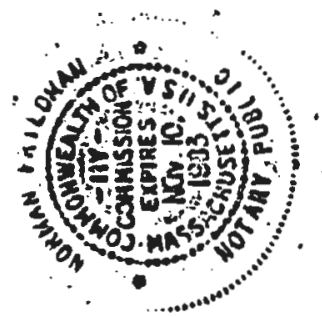

Edgartown, Mass. $\frac{\text { Qume } 12}{\frac{10}{10} \cdot \frac{79}{M}}$ Received and untered wid 572

Attest fecuesey lo, 
SSA PROPOSED COMPROMISE CONDITIONS

FLEET CAPACITY: The Authority will not increase the total capacity of the fleet beyond the capacity of the five vessels presently in use.

"DOLLY FREIGHT": The Authority confirms its October 1977 vote to continue dolly freight service to Island patrons. In continuing such service, the Authority will pursue, in accord with its management judgement, a change in the method of handling such freight which will involve the use of trucks and off site freight handling terminals, off-site from the Authority's docks, for the purpose of increasing the efficiency of ferry terminal operation and to reduce congestion in ferry terminal areas. The change in the method of providing such service will be reviewed with the Commission at a public hearing in advance of implementation, to enable the Authority to have the benefit of the views of the Commission. SECOND SLIP USE: (a) The second (standby slip) will not be used:

1. to expand scheduled service to and from Vineyard Haven

2. to decrease Oak Bluffs summer schedule service The Authority will continue to split summer season service between the ports of Vineyard Haven and Oak Bluffs as in 1978 scheduling.

(b) The second slip will be used to:

1. service ferry traffic while the primary slip is being reconstructed

2. provide service when the primary slip is disabled 
by any sort of casualty and awaiting or under repair

3. during summer schedule, when and if the Oak Bluffs ferry slip is disabled because of weather, casualty, or awaiting or under repair

4. service a vessel arriving in Vineyard Haven when the primary slip is occupied by another vessel, rather than delay or inconvenience patrons on board

5. to lay up a vessel when not in use; particularly in the off-season

SCHEDULING: The Authority will not increase the capacity of service provided in the summer season of 1978 . REVIEW OF PLANS AND SPECIFICATIONS: The Authority will review final construction contract plans and specifications as soon as prepared, with the Commission before finalizing such plans and specifications for bid, to enable the Authority to have the benefit of the views of the Commission. FINANCING: If federal grant assistance is not obtained to assist in the financing of reconstruction of the terminal, the Authority will return to the Commission for a public hearing to review:

1. alternative financing for the project prior to making any commitment to construct

2. the economic impact of the reconstruction on the Authority and the economy of the Island and any proposed bond issue by the Authority for the project ANCHORAGE AREAS: No additional space shall be taken by the Authority from present anchorage space in Vineyard Haven harbor to service the second slip. Conversely, no additional 
anchorage areas in Vineyard Haven will be established which infringe on present navigation lanes open to the Authority's terminal.

The foregoing are without prejudice to or waiver of the rights of the Authority or the Commission, and both expressly reserve their rights under their respective enabling acts.

In the event of circumstances beyond the Authority's control or changes in transportation needs, competitive conditions, or equipment not forseen at present, or other conditions or circumstances that indicate the desirability to the Authority of changes from the foregoing, the Authority shall review such changes with the Commission before implementation. The Authority reserves the right to make such changes as it deems appropriate under the authority of its enabling act, and the Commission reserves the right to enter under such order or render such decision as it may deem appropriate under the authority of its enabling act.

The intent of the foregoing is to endeavor to reconcile differences between the Authority and the Commission without litigation, to determine their respective rights, and, in the spirit of accomodation, to endeavor to reconcile such differences as now exist without compromise of the responsibility and authority of the Authority under its enabling act. 
HISTORY OF ANNUNL BAiLLO' QUESTION REGARDING THE MARTHA'S VINEYARD COMMISSION

ANNUȦ BALLOT - MAY 1976 - TISBUPY

Question: Shall the Town of Tisbury direct the Selectmen to take the necessary steps tc withdraw from the provisions of Chapter 637, Acts of 1974 which created the Martha's vineyard Commission.

Yes 527; No 566; Blanks $\cdot 8 i$

ANNUAC BALLOT - MAY 1977 - TISUUIRY

Question: Should the Town of Tisbur: take the appropriate action to withdraw from the Martha's Vineyard Commission provided that the Towns of Edgartown and Oak Bluffs are successful in withdrawing from the Martha's Vineyard Commission.

Yes 547 ; No 372

ANNUAL BALLOT - MAY 1978 - TISBIIRY

Question: Shall the Town of Tisbury drect the Selectmen to take all required legal steps to enable the Town to withdraw from the provisions of Chapter 637 of the Acts of 1974 and Chapter 831 of the Acts of 1976, as amended, which created the Martha's Vineyard Commission without the necessity of a further vote of the Town.

Yes 620 ; No 563

Chapter 306 (Approved June 28, 1978)

Section 1. The jurisdiction of the Martha's Vineyard Commission shall not include the Town of Tisbury. Said town shall not be represented in the membership of said Commission.

Section 2. This act shall take effect on July first, nineteen hundred and seventy-nine.

AÑNUĀL BALLOT - MAY 1979 - TISBURY

Question: Shall proposed legislation pending in the Massachusetts General Court, entitled "An Act Clarifying the Law Relative to the Protection of the Lands and Waters of the Island of Martha's Vineyard", which makes certain amendments to Chapter 831 of the Acts of 1977 and which will continue to include the Town of Tisbury in the membership of the Martha's Vineyard Comnission, be ap.proved without further vote of the town.

Yes 599; No 559

ANNUAI BALLOT - MAY 1980 - TISBURY

Question: Shall the Town of Tisbury vote to instruct its representative to the General Court to file the following petition in the legislature:

- authorizing the Town of Tisbury to withdraw from membership in the Martha's Vineyard Commission. This act shall take effect as of July $1,1980$.

(By Detition - This Question is Not Binding)

Yes 556; No 378; Blanks 30 


\section{$\because:$ \\ - 3 \\ : \\ ANNUAL BALLOT - APRIL 1976 - BDGARTOINN}

Question: Shall the Town direct Selectmen to take necessary steps to withdraw from the provisions of chapter 637.

Yes 283 ; No 249

Approved (Chapter 836 of Acts of 1977 ) by Legislature December 1977 to be put on the April 1978 ballot of Edgartown for voters acceptance to withdraw from Martha's vineyard Comnission July 1, 1978.

ANNUAL BALLOT - APRIL 1978 - EDGARTOWN

Question: Shall an act passed by the General Court in the year nineteen hundred and seventy-seven, entitled 'An Act authorizing the Town of Edgartown to withdraw from membership of the Martha's Vineyard Commission' be accepted.

Yes 675; No 554; Blanks 15

ANNUAL BALLOT - APRIL 1979 - EDGARTOWN

Question: (1)

Shall the Board of Selectmen and/or their designees enter into negotiations with the Martha's vineyard commission in an attempt to modify the legislation creating the Martha's Vineyard Commission in such a way as to make Edgartown's re-entry into the Martha's vineyard Commission acceptable to the majority of Edgartown's voters.

Yes 529; No 265; Blanks 54

Question: (2)

Should the jurisdiction and the membership of the Martha's vineyard Commission be expanded to include the Town of Edgartown, and shall the Selectmen be instructed to petition the General Court for legislation in the following form:

Section 1. The jurisdiction and the membership of the Martha's vineyard Commission shall be expended to include the Town of Edgartown if and when a bill currently pending before the General Court, entitled 'An Act Clarifying the Law Relative to the Protection of the Lands and Waters of the Island of Martha's Vineyard' (i.4022), filed on behalf of Tisbury which will make certain amendments of Chapter 831 of the Acts of 1977 , is enacted by the General court and becomes effective

Section 2. This Act shall take effect without further vote of the Town of Edgartown.

Yes 350; No 435: Blanks 63 


$$
\because \ddot{2}
$$

ANNUAAL BALLOT - APRIL 9976 - OAK BLUFFS

Question: Shall the Town direct" the selectrien to take the necessary steps to withdraw from the provisions of Chapter 637. Acts of 1974; which created the Martha's vineyard Commission.

Yes 287; No 282; Blanks $\ddot{149}$

$$
\begin{aligned}
& \text { Approved (Chapter '837 of Acts of 1977) by } \\
& \text { Legislature December } 1977 \text { to be put on the } \\
& \text { April } 1978 \text { Ballot of Oak Bluffs for voters } \\
& \text { acceptance to withdraw from Martha's vine- } \\
& \text { yard Commission July 1, 1978. }
\end{aligned}
$$

ANNUAJ. BALLOT - APRIL 1978 - OAK BLUFFS

Question: Shall an act passed by the General court in the year 1977 'An Act Authorizing the Town of Oak Bluffs to Withdraw from membership in the Martha's vineyard Commission' be accepted.

Yes 356 ; No 426 ; Blanks 81 


\section{SELECTED BIBLIOGRAPHY}

1. Alan M. Voorhees and Associates, Inc. Study of Beach Street Water Street Intersection For Town of Tisbury, Massachusetts. June 19, 1978 .

2. American Law Institute. A Model Land Development Code. Executive Office of The American Law Institute. Philadelphia, 1975.

3. Barrs, Bonny, Nelson, S., Taipale, E. "Martha's Vineyard: The Prospects for Regional Cooperation." In The Land Use Controversy in Massachusetts. Edited by Lawrence Susskind. Cambridge: MIT Press, 1975.

4. Bastress, Susan B. "The Martha's Vineyard Commission: A Regional Approach to Controlling Growth Within Island Limits" Washington, D.C. George Washington University, 1980. Mimeographed.

5. Ewing, Douglas. Martha's Vineyard Commission. Oak Bluffs, Massachusetts. Interview. August 1980.

6. Gifford, K. Dunn. "An Islands Trust: Leading Edges in Land Use Laws." Harvard Journal on Legislation. Volume II, No. 3. (April 1974): pp 417-61.

7. Harvard University, Department of City and Regional Planning. An Analysis of the Impact on Martha's Vineyard of the Woods Hole, Martha's Vineyard, and Nantucket Steamship Authority's Proposed Expansion of Facilities. Boston: Harvard University, April, 1979.

8. Massachusetts. An Act Protecting the Land and Water on Martha's Vineyard. G.L. C 637.

9. Massachusetts. An Act Further Regulating the Protection of the Land and Waters of the Island of Martha's Vineyard. G.I. C 831. 1977 .

10. Massachusetts. Dukes County Planning and Economic Development Commission. An Economic Base Study for Dukes County, Massachusetts. Fall 1973.

11. Massachusetts. Martha's Vineyard Commission. Decisions and Regulations to Implement Guidelines for Districts of Critical Planning Concern. 1976-77.

12. Massachusetts. Martha's Vineyard Commission. Development of Regional Impact Decision Re: Coastal Construction. June 7, 1979.

13. Massachusetts. Martha's Vineyard Commission. 208 M.V. Water Quality Plan. October, 1979. 
14. Massachusetts. Superior Court for the County of Dukes. G.E. Carter, Trustee v. Anderson.

Civil Action No. 1969.

15. Massachusetts. Suffolk County Supreme Judicial Court. Island Properties, Inc. Trustee v. Martha's Vineyard Commission. Civil Action No. 76-172. March 23, 1977.

16. Massachusetts. Superior Court for the County of Dukes. McCarthy v. Planning Board of Edgartown, Mass. Adv. Sh. 1623. July 2, 1980 .

17. Massachusetts. Supreme Judicial Court for the Commonwealth of Boston. Woods Hole, Martha's Vineyard, and Nantucket Steamshio Authority v. Martha's Vineyard Commission. Case No. SJC-2036. June 4, 1980.

18. Metcalf and Eddy, Inc. Comprehensive Plan for Dukes County Massachusetts. Boston: Metcalf and Eddy, Inc. 1969.

19. Muniak, Dennis C. "The Institutionalization of Local Environmental Planning in the Northeast United States: The Municipal Environmental Conservation Commission Movement." Planning and Administration. Volume 7, Number 2. Fall, 1980.

20. New York Times. 11 October, 1971. p. 31.

21. Tyler and Reynolds and Craig. Memorandum prepared by Donald L. Connors to MVC conerning Steamship Authority Question. May 5, 1978.

22. U. S. Department of Commerce. Bureau of the Census. Twentieth Census of the United States, 1980: Population and Housing. Preliminary Counts for Dukes county.

23. Vineyard Gazette. 1 January 1976 - 20 November, 1980.

24. Wild, Michael. Martha's Vineyard Commission. Oak Bluffs, Massachusetts. Interview. August 1980. 